Portland State University

PDXScholar

Master of Environmental Management Project

Reports

Winter 2018

\title{
Long-Term Managed Flooding to Control Invasive Phalaris arundinacea L. and Help Restore Native Vegetation in an Urban Palustrine Wetlands Ecosystem
}

Robert P. Lascheck

Portland State University

Follow this and additional works at: https://pdxscholar.library.pdx.edu/mem_gradprojects

Part of the Environmental Studies Commons, and the Natural Resources Management and Policy Commons

Let us know how access to this document benefits you.

Recommended Citation

Lascheck, Robert P., "Long-Term Managed Flooding to Control Invasive Phalaris arundinacea L. and Help Restore Native Vegetation in an Urban Palustrine Wetlands Ecosystem" (2018). Master of Environmental Management Project Reports. 36.

https://pdxscholar.library.pdx.edu/mem_gradprojects/36

https://doi.org/10.15760/mem.7

This Project is brought to you for free and open access. It has been accepted for inclusion in Master of Environmental Management Project Reports by an authorized administrator of PDXScholar. Please contact us if we can make this document more accessible: pdxscholar@pdx.edu. 
Long-term managed flooding to control invasive Phalaris arundinacea $\mathrm{L}$. and help restore native vegetation in an urban palustrine wetlands ecosystem

\author{
Robert P. Lascheck \\ Portland State University
}

March 23, 2018 


\section{ABSTRACT}

We sought to determine the effects of 13 years of hydrologic management on the wetland plant community in Smith and Bybee Wetlands Natural Area (SBW), an 809 ha palustrine wetland complex in north Portland, Oregon. Previous management efforts resulted in an altered hydrologic regime; historically high water levels in spring and low water levels in fall were replaced by persistent water levels with minimal annual variations. A water control structure was installed in 2003 to better approximate historic seasonal hydrologic changes to reduce invasive Phalaris arundinacea (reed canarygrass) cover and promote native wetland vegetation growth. Vegetation monitoring has been carried out in three phases since project initiation (2003-2004, 2008-2009, and 2015-2016) to assess restoration efforts. Using lineintercept and differential leveling methods, we measured 25 randomly established transects ranging from $21.5 \mathrm{~m}$ to $280.7 \mathrm{~m}$ (mean: $92.87 \mathrm{~m}$ ) during monitoring years for vegetation and elevation to determine changes in vegetation in relation to seasonally varying water levels. Overall, reed canarygrass percent cover has decreased from $46.5 \%$ in 2003 to $17.6 \%$ in 2016 (McNemar's test; $p<0.05$ ) across all transect elevations. Reed canarygrass has been replaced significantly by seven native plant species with $\geq 5 \%$ cover on site (McNemar's test; $p<0.05$ ). Native Persicaria amphibia (smartweed) has replaced reed canarygrass as the dominant species on site, increasing in cover from 20.2\% in 2003 to $67.9 \%$ in 2016 (McNemar's test; $\mathrm{p}<0.05)$. Smartweed also replaced all other common species on site except for Salix lucida lasiandra (McNemar's test; $\mathrm{p}<0.05$ ). Other common native species (Bidens cernua, Eragrostis hypnoides, Eleocharis palustris, and Cyperus sp.) experienced earlier declines in cover between 2003 and 2009, but have since increased in cover primarily in low transect elevations in relation to lower inundation rates during their early growing seasons. Species diversity has declined significantly since 2003 (Shannon diversity index $=2.44( \pm 0.01$ SD) in 2003 to $2.10( \pm 0.01$ SD) in 2016; Hutcheson $p<0.05)$. Diversity was inversly correlated with reed canarygrass presence in 2003 (Spearmen's rho $=-0.79 ; \mathrm{p}<0.05)$ and Persicaria presence in 2016 (Spearmen's rho = - 
$0.70 ; p<0.05)$. These findings demonstrate that hydrologic management of a wetland system can be effective at reducing the presence of reed canarygrass and increasing native wetland vegetation by recreating historic hydrologic conditions that include increased inundation during the early growing season of reed canarygrass. Initial long inundation periods were most effective at reducing reed canarygrass, but did not need to be maintained indefinitely. Shortening and varying the inundation periods in later years after reed canarygrass has been reduced can be effective at maintaining lower levels of reed canarygrass while simultaneously increasing native species cover. 


\section{ACKNOWLEDGEMENTS}

I would like to thank Alan Yeakley and Elaine Stewart for their immense amount of assistance and support throughout this project. Alan's patience, kindness, insights, support, and ability to provide personalized and focused attention regardless of other responsibilities were all more than I could have asked for in an advisor and mentor. Elaine's positivity, enthusiasm, intuition, drive, and passion for her work were inspiring and incredibly motivating for me throughout this process. Also, their long time professional collaboration and personal friendship has shown me the value of what can be achieved when working together rather than in isolation. l'd also like to thank Joe Maser for sharing his wealth of knowledge in this subject area, for providing support and encouragement to me throughout my time at PSU, and for his excellent insight and assistance on this project. It's hard for me to count the number of ways I have grown and evolved both professionally and personally during my time in this program, all thanks to this amazing committee.

l'd also like to thank everyone who had a hand in assisting me with this project along the way. Thank you to all the volunteers who accompanied me out in the field: Laura Miller, Natalie Rogers, Steven Murschel, Patrick Davis, Matt Rollins, Dennis Eickhoff Jr, John Zalusky, Dana Denny, and Jenny Pugh. You all exhibited so much enthusiasm, excitement, and encouragement that brightened many a cloudy, often rainy late fall field day. Thanks to fellow members of the Yeakley lab, in particular Christa Von Behren and Sarah Kidd, for their support and assistance in completing this project and in navigating the stresses of graduate school life. I'd also like to thank the Metro staff at the St. John's Prairie, in particular Michael Guebert, for allowing me to use their surveying equipment and granting me site access.

Thanks to Metro Regional Government for the funding and allowing me to carry out this project. I am incredibly grateful for this amazing opportunity that was only possible because Metro had the resources and drive to make it happen. Thanks also to Portland State University for the willingness and ability to collaborate with Metro on this endeavor. 
Lastly, thank you to all my friends and family that have supported me throughout this journey. Mom, thank you for all the years of unquestioning support and encouragement, and for roughing it out in the field with me on some particularly exhausting days. Jenny, I couldn't ask for a more helpful and motivating partner. I'll never forget how much extra responsibilities you took on to help me focus on this work. I love you. 


\section{Table of Contents}

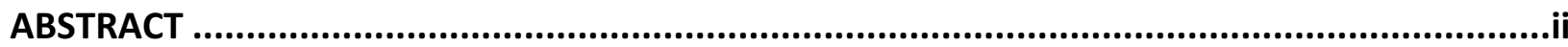

ACKNOWLEDGEMENTS.......................................................................................................

LIST OF TABLES

LIST OF FIGURES

INTRODUCTION ................................................................................................................... 1

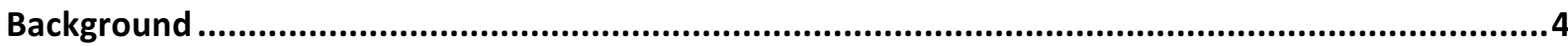

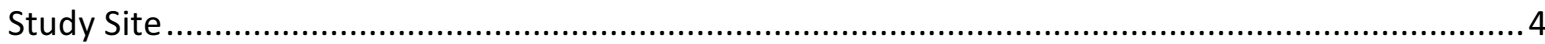

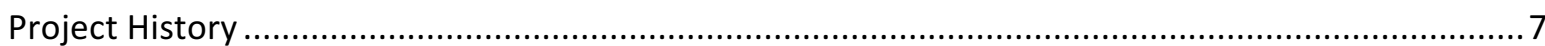

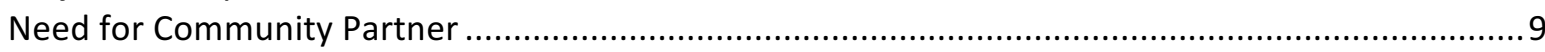

Research Questions ............................................................................................. 10

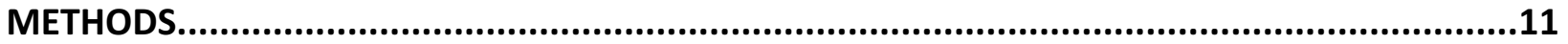

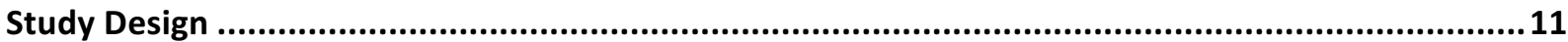

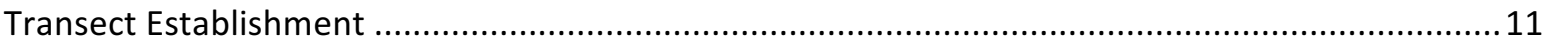

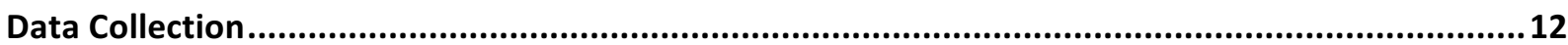

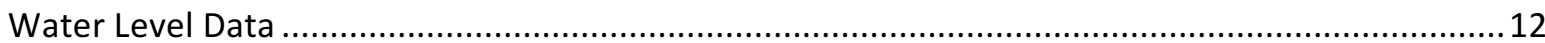

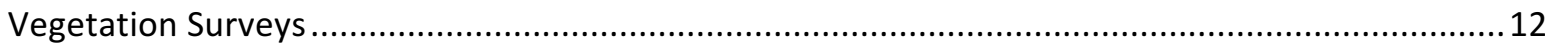

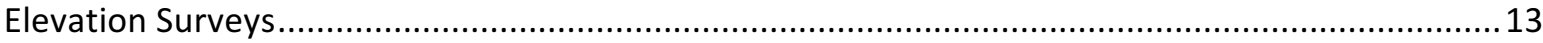

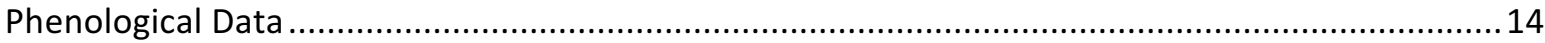

Data Analysis .............................................................................................................16

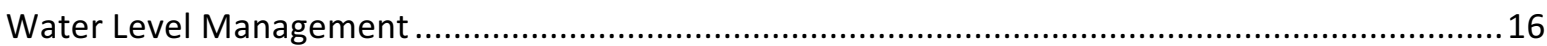

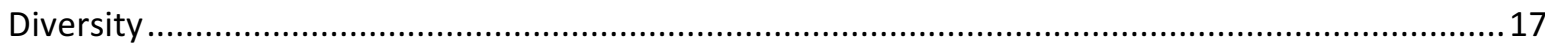

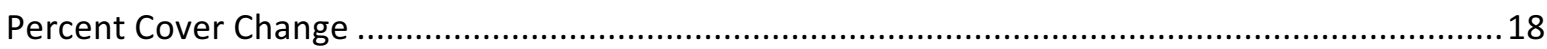

Percent Cover Change by Elevation and Inundation ...................................................... 18

Percent Cover Change by Wetland Indicator Type and Elevation ............................................19

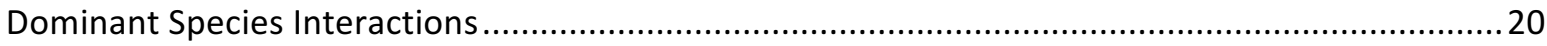

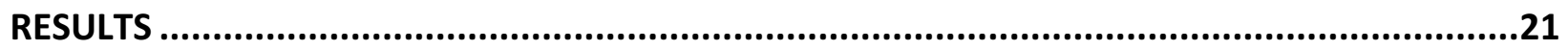

Water Level Management ........................................................................................21

Water Elevations Relative to the Columbia River ............................................................22

Diversity................................................................................................................24

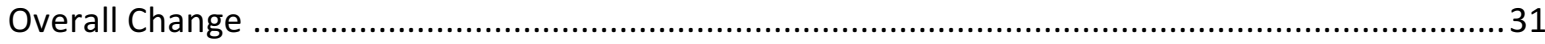

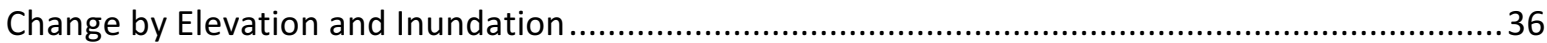

Change by Wetland Indicator Type and Elevation..........................................................47

Dominant Species Interactions ..................................................................................

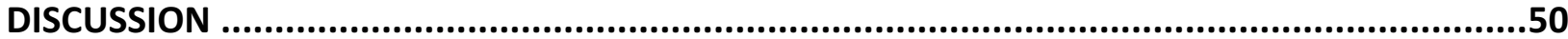

Water Level Management ..........................................................................................50

Diversity.................................................................................................................52

Percent Cover........................................................................................................5

Phalaris arundinacea L. (reed canarygrass) and Persicaria sp. (smartweed) ................................54

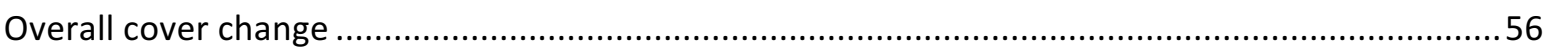




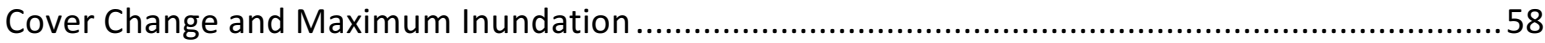

Conclusion / Management Implications .........................................................................................60

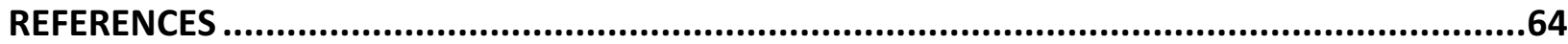

Appendix A: Common Species Percent Cover Change ...................................................75

Appendix B: Hydrologic Management ...........................................................................76

Appendix C: Community Composition 2003-2016 ..........................................................88 


\section{LIST OF TABLES}

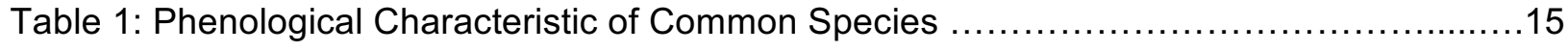

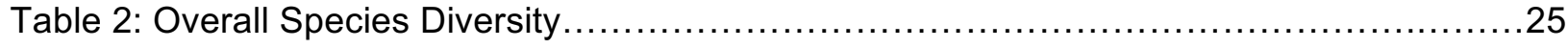

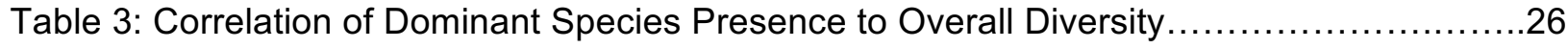

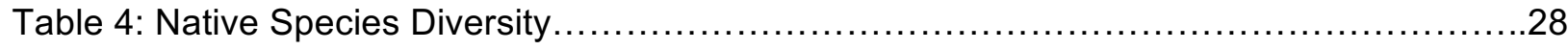

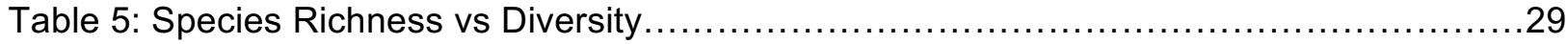

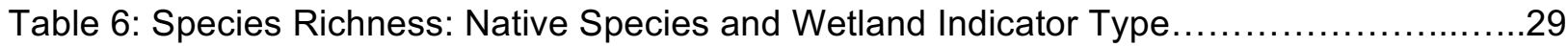

Table 7: McNemar's Test of Co-Dominant Species Replacement...........................49 


\section{LIST OF FIGURES}

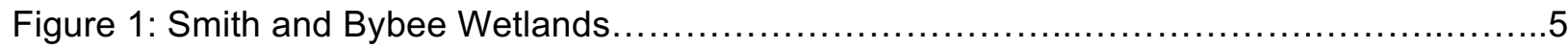

Figure 2: Annual Columbia River Stream Flow: Historic vs Current.........................6

Figure 3: Smith and Bybee's Water Control Structure (WCS) $\ldots \ldots \ldots \ldots \ldots \ldots \ldots \ldots \ldots \ldots \ldots \ldots$

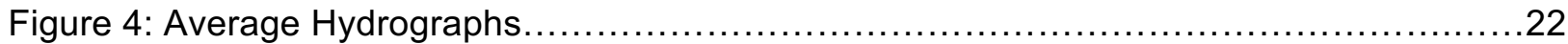

Figure 5: Water Elevations During Active Water Management Relative to the Columbia River..23

Figure 6: Dominance Diversity Curves for (a) All Species and (b) Native Species Only.........30

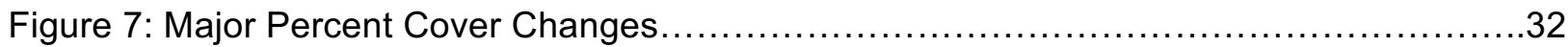

Figure 8: Cover Change by Elevation and Maximum Inundation for Phalaris arundinacea.......38

Figure 9: Cover Change by Elevation and Maximum Inundation for Persicaria sp...............39

Figure 10: Cover Change by Elevation and Maximum Inundation for Ludwigia palustris.........40

Figure 11: Cover Change by Elevation and Maximum Inundation for Salix Iucidia lasiandra.....41

Figure 12: Cover Change by Elevation and Maximum Inundation for Bidens cernua.............42

Figure 13: Cover Change by Elevation and Maximum Inundation for Eragrostis hypnoides......43

Figure 14: Cover Change by Elevation and Maximum Inundation for Eleocharis palustris........44

Figure 15: Cover Change by Elevation and Maximum Inundation for Cyperus sp...............45

Figure 16: Cover Change by Elevation and Maximum Inundation for Veronica sp...............46

Figure 17: Wetland Indicator Type Changes Over Time by Elevation........................47 


\section{INTRODUCTION}

Many wetland ecosystems throughout the United States, as well as the floodplains in which they exist, have experienced degradation over the past two centuries (Dahl 1990). These alterations have been so widespread that unaltered floodplains are now considered some of the most endangered ecosystems in the world (Buijse et al., 2002). Much of this degradation is driven by anthropocentric changes and controls placed on river systems through the construction of dikes, levees, dams and other structures that alter a system's hydrology (Michner and Haeuber 1998, Moorhead et al. 2008). This can result in floodplain habitats such as wetlands becoming disconnected from these more controlled and channelized systems, which often results in wetlands becoming degraded or disappearing all together (Warren et al. 2002). A comprehensive analysis of historic wetland coverage across the U.S. found that, by 1990, over half of all wetlands in the lower 48 states had been lost (Dahl 1990). Comprehensive efforts have been made for some decades now to combat these losses and restore and protect our nation's wetlands, with limited success. The overall trend of wetland presence in the contiguous United States as of 2010 was still in decline (Dahl 2011).

One method of restoration that has been successful in some previous studies has been to restore the historic hydrologic conditions of a wetland, often through the removal of dikes or levees. This method has promoted native vegetation, reduced invasive species presence, and promoted local fish, wildlife, and macroinvertebrate populations (Warren et al., 2002, Tanner et al., 2002, Mulhouse and Galatowitsch 2003, Sullivan et al. 2014). The local hydrologic regime is one of the most important factors in the overall health of a wetland (Mitsch and Gosselink 2015), and hence effective hydrologic management can be a linchpin to success in restoration activities.

The amount of water and timing of water level fluctuations within a system are often critical factors that need to be considered in the restoration process (Van der Valk 2005, 
Raulings et al. 2010, Raulings et al. 2011, Sullivan et al. 2014, van der Valk and Mushet 2016). A seasonally varying water regime can help promote diversity by allowing for species that prefer differing levels of inundation to coexist and promoting seed bank reestablishment (Keddy and Reznicek 1986, van der Valk et al. 1994, van der Valk et al. 2016). By restoring such hydrologic dynamics, it can also help prevent and/or deter the establishment of invasive species (Miller and Zedler 2003, Molofsky et al. 1999, Paveglio and Kilbride 2000, Jenkins et al. 2008). Recent investigations into the wet-dry cycles of prairie pothole wetlands in North America have shown that even slight (0.1-0.2 m) changes in water depths can shift vegetation populations towards wetter or dryer species assemblages and that climate change may result in widespread changes throughout this region (van der Valk and Mushet 2016). This relationship, while well documented, is quite complex and the number of variables involved can make applying this concept to a wetland restoration project difficult.

To restore wetland ecosystems, it is vital that we understand the relationship between wetland hydrology and vegetation at a local level. The use of long-term monitoring in wetland restoration projects is an essential component to comprehend this relationship. If the hydrology is not successfully restored in a restoration project, it can often lead to overall restoration failure and loss or degradation of the wetland (Mulhouse and Galatowitsch 2003, Sullivan et al. 2014, Moreno-Mateos et al. 2015). Previous studies have shown that many restoration projects receive no monitoring, and many of those that do are only monitored for two to five years (Nedland et al. 2007, Kettenring and Adams 2011). The Oregon Department of State Lands and U.S. Army Corps of Engineers, two governing agencies that oversee wetland mitigation monitoring in Oregon, only require five years of post-project monitoring to determine if restoration efforts were successful or not (Compensatory Mitigation for Losses of Aquatic Resources 2008, Oregon Department of State Lands 2016). However, successful evaluation of a restored wetland has been shown to be much more achievable after 15 years or more (Mitsch and Wilson 1996, Zedler and Callaway 1999, Borja et al. 2010, Moreno-Mateos et al. 2015). 
Therefore, it is essential that wetland restoration projects receive long-term monitoring to understand if the methods that are being used today such as altering the hydrology of the site are effective means of long-term restoration. Moreover, long-term monitoring is vitally needed if adaptive management is to be implemented.

Adaptive management is a technique in wetland restoration that has grown in popularity over the last few decades as researchers have discerned that there are a large number of uncertainties and unknowns that can negatively affect restoration efforts, especially when factoring in climate change (Tompkins and Adger 2004, Patten 2006, Simenstad et al. 2006, Thorslund et al. 2017). While the concept of adaptive management has grown in popularity, the results of projects that have applied adaptive management principles have been mixed at best (Allen and Gunderson 2010, Susskind et al. 2012, Westgate et al. 2013, Healy et al. 2015). Project failure has often been due to a lack of comprehensive, long-term monitoring or a lack of understanding of the underlying ecological processes affecting the system in question, which are essential components in the adaptive management process (Allen and Gunderson 2010, Susskind et al. 2012, Westgate et al. 2013). Intensive, iterative, long-term monitoring is often the most difficult part of a project to carry out due to the amount of resources and time that are required to produce adequate results, but it is also critically important for successfully applying adaptive management. Successful projects also consider adaptive management throughout the entire process by defining restoration goals and formalizing methodologies for monitoring and future management actions at the initial project phase, and basing decisions on current, sound scientific data (Patten 2006, Convertino et al. 2013, Healy et al. 2015, Ebberts et al. 2017). Understanding and applying the adaptive management techniques used in successful projects help to maximize the chance of successful wetland restoration.

Adaptive management and long-term monitoring have been useful tools in the restoration and management of wetlands dominated by invasive species such as Phalaris arundinacea L. (reed canarygrass) (Lavergne and Molofsky 2006, Jenkins et al. 2008, 
Kettenring and Adams 2011, Healy et al. 2015). Phalaris is a highly competitive, invasive species that is quite difficult to manage due to its phenotypic plasticity that allows it to thrive in a variety of ecological conditions (Apfelbaum and Sams 1987, Katterer and Andren 1999, Lavergne and Molofsky 2004, Herr-Turoff and Zedler 2006, Jenkins et al. 2008, Kidd and Yeakley 2015). It prefers to grow in moist environments and is able to adapt to a variety of hydrologic conditions (Galatowitsch et al. 1999, Katterer and Andren 1999, Kercher and Zedler 2004, Wilcox et al. 2007). Its growing season begins in early spring, at which time it is able to quickly spread vegetatively via a dense rhizomatous root system and expediently produce a high amount of above-ground biomass (Laverge and Molofsky 2004, Adams and Galatowitsch 2005). These characteristics allow it to outcompete many native species, especially in areas that have recently experienced a disturbance event or alterations that could shift the ecological state of the system, and make management of this species quite difficult (Lavergne and Molofsky 2006, Wilcox et al. 2007, Jenkins et al. 2008, Healy et al. 2010, Martina and von Ende 2012, Kidd and Yeakley 2015). This has resulted in Phalaris becoming the dominant species in wetland and riparian ecosystems across multiple regions including northwestern Oregon, where we conducted our study (Lev et al. 1994, Guard 1995, Cooke 1997, Jenkins et al. 2008, Von Behren et al. 2013, Kidd and Yeakley 2015, Wielhoefer et al. 2016).

\section{Background}

\section{Study Site}

Smith and Bybee Wetlands Natural Area (SBW) is an 809 ha natural area located in North Portland (lat $45^{\circ} 37^{\prime} \mathrm{N}$; long $122^{\circ} 45^{\prime} \mathrm{W}$ ) five kilometers southeast of the confluence of the Columbia and Willamette Rivers. It consists of primarily wetland and riparian habitats dominated by the large palustrine, emergent wetlands known historically as Smith Lake and Bybee Lake 
(Figure 1). Smith and Bybee are hydrologically connected to the Columbia River floodplain via a meandering channel connecting Smith Lake by Bybee Lake and an outlet to the north arm of the Columbia Slough.

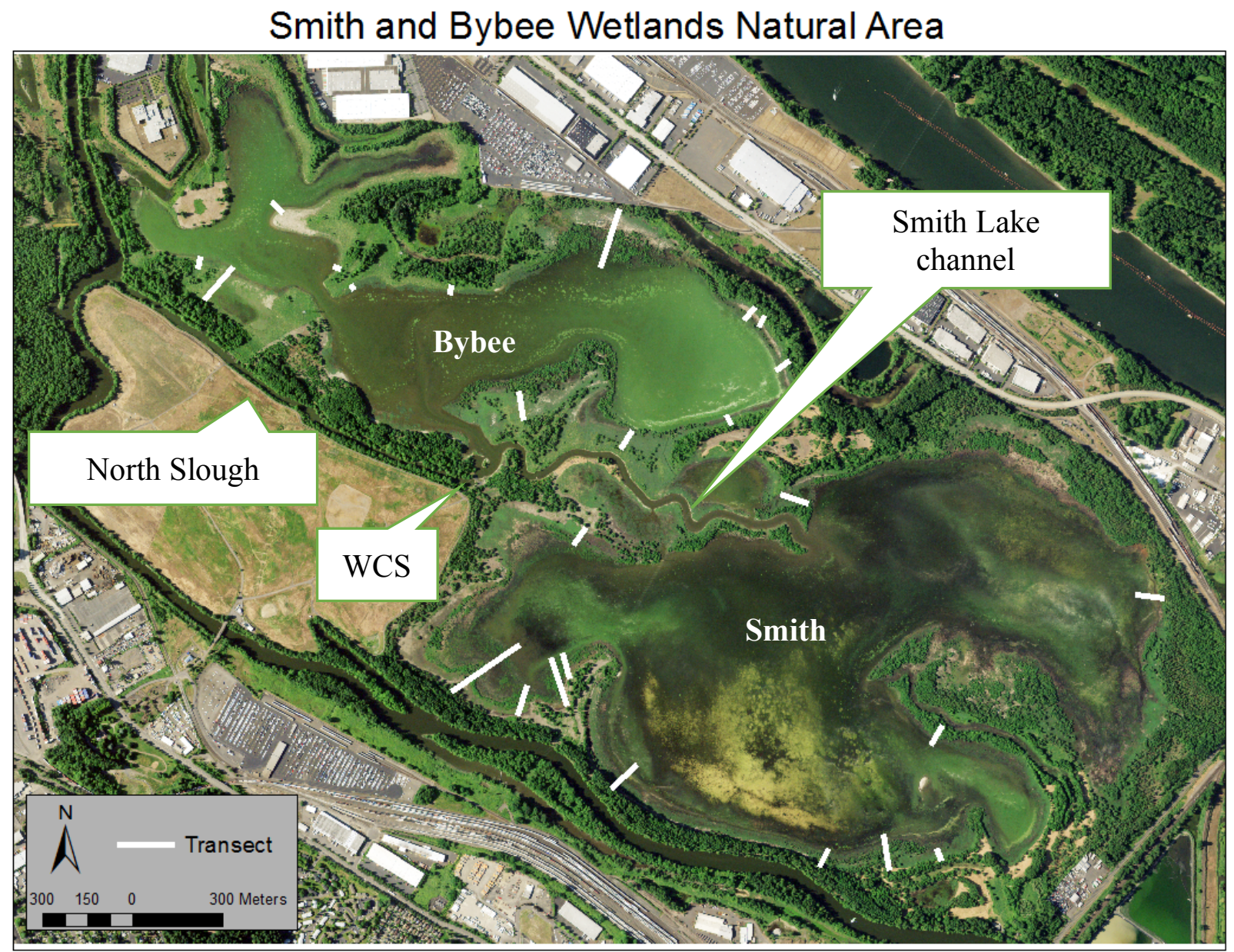

Figure 1: Smith and Bybee Wetlands.

Aerial photograph of Smith and Bybee Wetlands Natural Area (SBW). Transects, indicated by the white lines, are shown to scale. The water control structure (WCS) is located at the point where SBW meets the Columbia Slough, which is the main source of hydrology for the wetlands. The WCS controls water levels within SBW by regulating flows from the Columbia Slough and retaining water in SBW during a portion of the year.

This system has experienced extensive anthropogenic hydrologic alterations over the past century. Historically these wetlands experienced seasonal fluctuations with low water levels in the late summer and fall being recharged by winter rains and snow melt bringing spring freshets down the Columbia River (Jenkins et al. 2008, Farrelly 2012). Columbia River water 
management reduced spring flows by $43 \%$ (Figure 2, Bottom et al. 2005), reducing water availability to SBW. Another drastic change to SBW's hydrology occurred in 1982 when managers installed an earthen dam at the location where the Bybee Lake outlet meets the North Slough following a severe outbreak of avian botulism in the lower Columbia River estuary. The dam was intended to retain water in the system into early fall to avoid future outbreaks by dispersing birds and slowing the spread of this disease (Stewart 2017). The dam was equipped with a weir to manage flow, but it was not maintained and eventually it rusted shut. A series of very dry years from 2000 to 2003 resulted in severely diminished water levels within SBW, including the system completely drying in 2001.

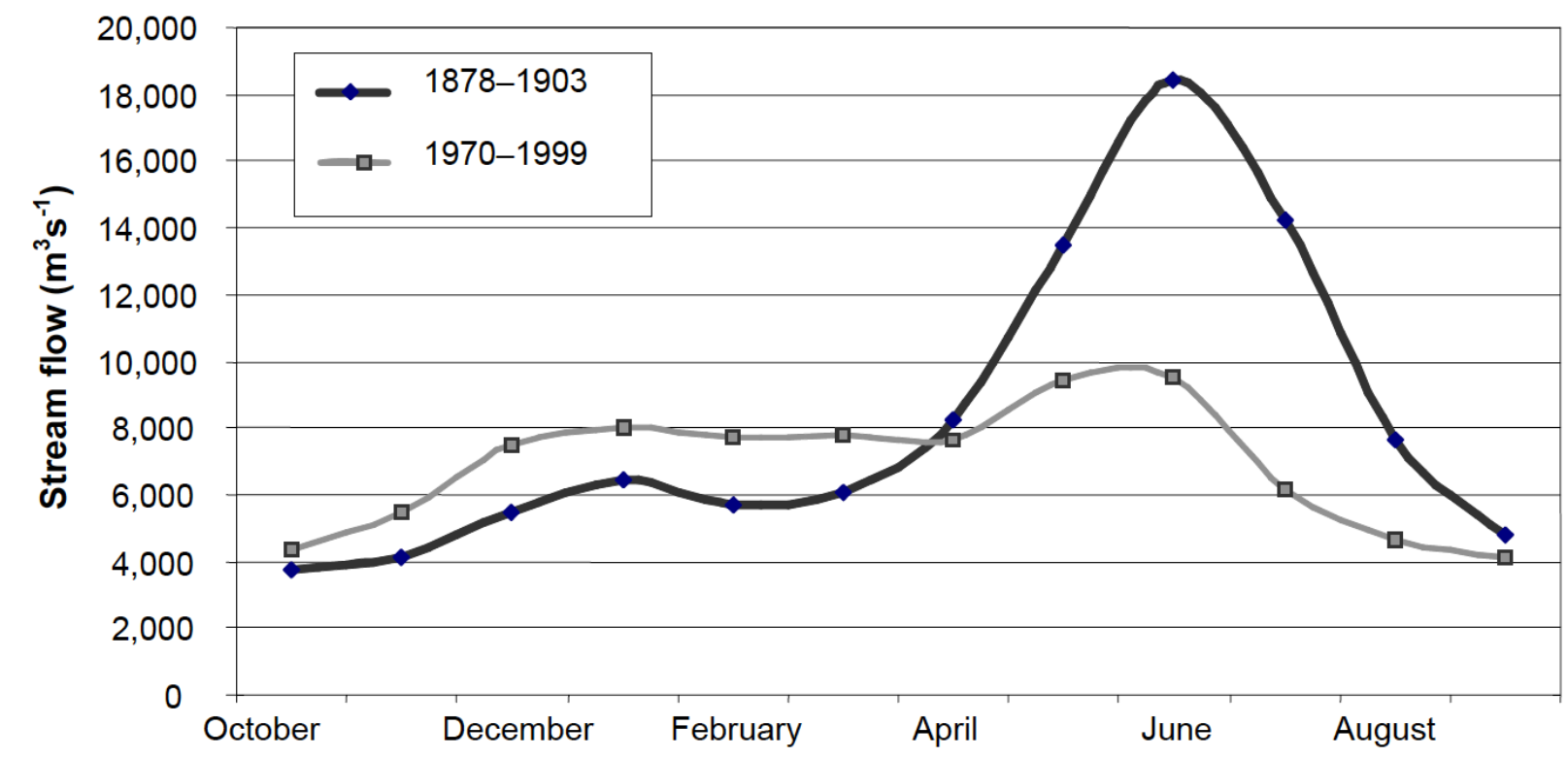

Figure 2: Annual Columbia River Stream Flow: Historic vs Current. Graph taken from Bottom et al. (2005) showing "Changes in the annual flow cycle of the Columbia River at the Beaver Army Terminal, 1878-1903 (from 1878 to 1894 not all daily values are present from Albany) versus 1970-1999. (Data adapted from USGS records.)" Beaver Army Terminal is located on the Columbia River main stem downstream of Smith and Bybee Wetlands (SBW) and representative of overall hydrologic patterns and changes experienced in SBW. Stream flow was used to represent water levels due to the absence of a comprehensive dataset of historic water elevations and the assumption that increased stream flow correlates to higher water elevations and vice-versa (Bottom et al. 2005).

Vegetation within SBW experienced substantial changes in response to the altered hydrologic regime. Forests that were historically dominated by Salix sp. (willow) and Fraxinus 
latifolia (Oregon ash) died with permanent flooding and mudflats being drastically reduced. Areas dominated by Persicaria amphibia (water smartweed) and other native emergent plants declined as well (Lev et al. 1994, Jenkins et al. 2008, Farrelly 2012). Many of these areas that experienced declines in native vegetation were replaced by monocultures of Phalaris, which occupied $43 \%$ of the emergent wetland zone around both Smith and Bybee Lakes by 2003 (Jenkins et al. 2008). This loss of wetland vegetation, decrease in diversity, and increase of invasive species is consistent with previous studies that have found similar patterns in cases where systems with seasonally varying hydraulic regimes shifted to more stable ones (Keddy and Reznicek 1986, Warren et al. 2002, Barrett et al. 2010). Lower, stagnant water levels provided the moist environment that Phalaris prefers, but not enough inundation for many of the native obligate wetland species. Also, Phalaris' growing season begins before that of many of the native wetland species, which gives it an advantageous head start and allows it to form dense rhizomatous mats before many species even germinated (Guard 1995, Cook 1997, Jenkins et al. 2008, Farrelly 2012). The current natural resource managers of SBW headed up by Elaine Stewart of Metro, a regional government authority and partial owner of SBW, hypothesized that increased inundation at a critical season and seasonally varying water levels similar to historic ones could reduce Phalaris presence and promote the establishment of native wetland vegetation.

\section{Project History}

In late 2003, the Stewart team replaced the earthen dam that was installed in 1982 with a water control structure (WCS) (Figure 3). The goal of this project was to hydraulically reconnect SBW to the Columbia River system and use the WCS to control water levels within SBW to control the spread of Phalaris, to support native vegetation, to provide ingress and egress for salmonids and to other fish species, and provide suitable habitat for migrating shorebirds and waterfowl (Jenkins et al. 2008). The WCS contains: reverse tide gates that allow 
flow into SBW and restrict out flow; stop-logs, which are boards that stack on top of one another and span the entirety of multiple openings in the WCS to set the water height within SBW to the height of the top-most installed board (Figure 3) and a fish ladder to aid in passage. The management plan that Metro enacted post-construction was to retain high water levels that usually occur in winter and early spring within SBW until late spring / early summer, followed by a summer drawdown period that would result in low water levels and exposed mudflats in late summer and fall. This management plan was designed to mimic the historic hydrologic regime of SBW to support native wetland plant species and reduce the presence of Phalaris by inundating the species during the early to mid-growing season (Jenkins et al. 2008, Farrelly 2012).

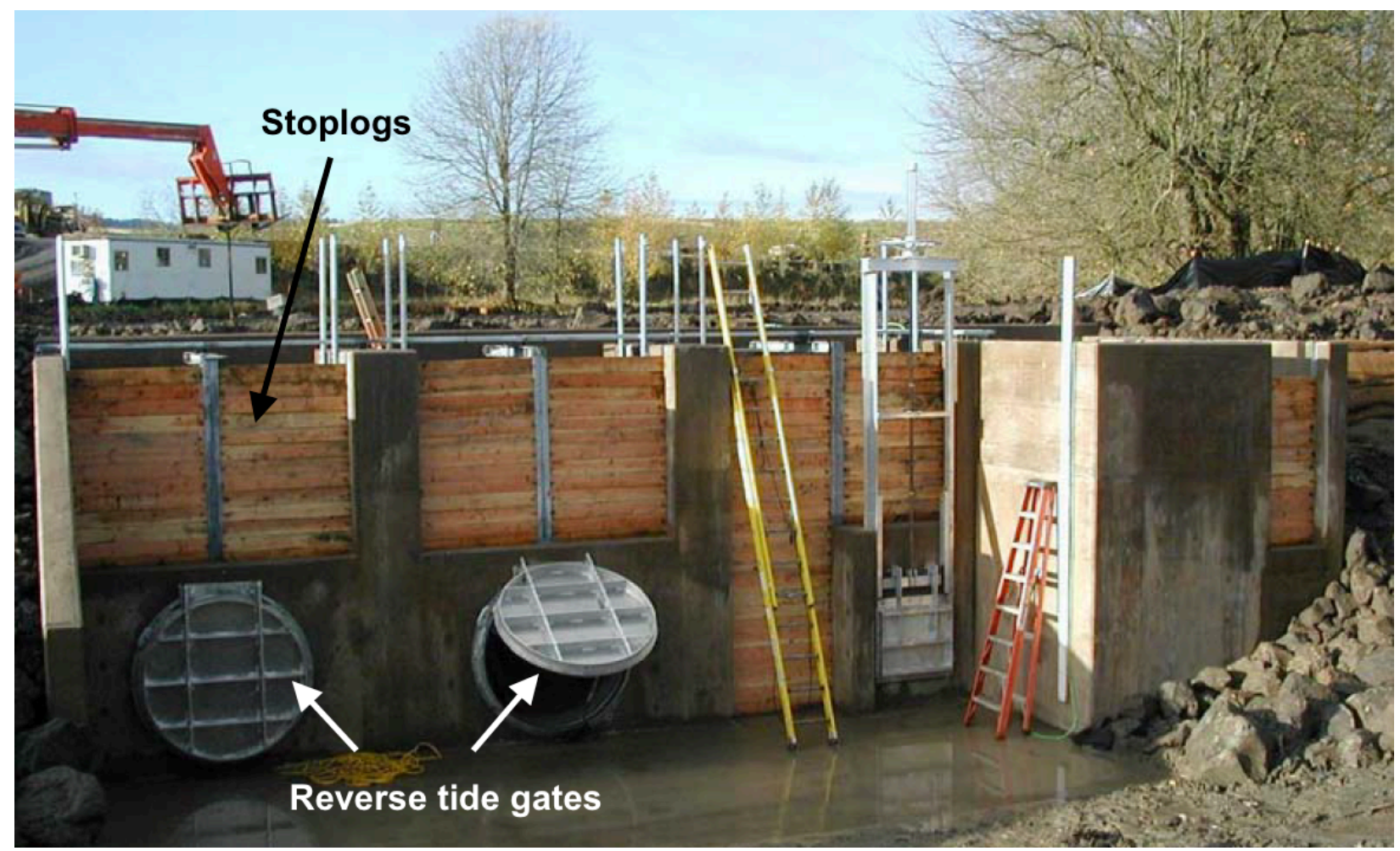

Figure 3: Smith and Bybee's Water Control Structure (WCS).

The WCS as it was being installed in 2003. The photo was taken from the Smith and Bybee (SBW) side of the structure. Reverse tide gates allow flow into SBW and restrict flow out of the system. Stoplogs set the water level within SBW to the height of the top-most installed board, and each board can be removed individually to control the rate of drawdown. 
The Stewart team has worked in collaboration with the research lab of Alan Yeakley at Portland State University since the installation of the WCS in 2003 to conduct long term monitoring to study the effects the new hydrologic regime has on the wetland vegetation within SBW. This long term monitoring plan was designed and implemented in 2003 prior to the WCS installation. The first analysis by the Jenkins study established baseline conditions prior to the WCS installation and analyzed conditions after one year of management (Jenkins et al., 2008). A second analysis by the Farrelly study took place in $2008-2009$ to examine management effects after the first 5-6 years of management (Farrelly 2012). These studies found a reduction in Phalaris over the first five years of management in areas that were inundated by at least $0.6 \mathrm{~m}$ of water. The Farrelly study also observed decreases in both the percent cover of many species and overall diversity within SBW.

The results of these studies led the Stewart team to adapt their management strategy to begin drawdown earlier in the summer to allow more time for plants to establish during low flow periods. Managers applied this strategy from 2010 to 2014. In 2015 and 2016 the WCS was left completely open to make improvements and update safety features. This resulted in water levels within SBW being controlled entirely by the flow within the Columbia River. This lack of active management meant that no water was being retained at any point in 2015 or 2016 . We hypothesize that this could allow for the reestablishment of species in areas that were previously inundated for longer periods, which could be an advantageous opportunity for native species, but it could also be an opportunity for aggressive invasives such as Phalaris.

\section{Need for Community Partner}

The partnership between the Yeakley lab at Portland State University and the Stewart team at Metro has been necessary to provide this unique opportunity to investigate the longterm effects of hydrologic management on wetland vegetation and readily apply the knowledge gained from this investigation to effectively manage this ecosystem's health. This study aims to 
examine changes to SBW over a 13-year period, and could not be carried out without the participation of the Stewart team in actively managing yearly water levels and adapting management efforts based on the results of the previous two studies. These studies are providing researchers with a better understand long-term relationships between wetland hydrology and vegetation, while simultaneously providing restoration practitioners with information on how to most effectively manage and restore this large, complex ecosystem. This is an excellent example of how a partnership between restoration practitioners and academic researchers can benefit both parties to further our understanding of wetland ecology and restoration while simultaneously carrying out effective restoration efforts.

\section{Research Questions}

This study is aimed to build from the results of the previous two studies to understand the long term effects of water management within SBW on the vegetation communities within this wetland complex. Specifically, our aim is to investigate these questions:

1. How effective is the hydrologic management of a wetland system using a water control structure for reducing invasive species presence and promoting native vegetation growth?

2. How has Phalaris arundinacea cover and distribution changed both in overall extent and in landscape position since the implementation of the hydrologic management regime?

3. How have native wetland vegetation populations changed both in overall extent and in landscape position since the implementation of the hydrologic management regime?

4. In what ways has the hydrologic management regime affected the presence and distribution of species assemblages of different wetland indicator categories? 


\title{
METHODS
}

\author{
Study Design
}

This study uses the design and methods established by Jenkins et al. (2008) and further refined by Farrelly (2012). Any deviations or modifications to these methods were due to environmental and time constraints on this project and are addressed in detail. There were no modifications made to the types of data collection and analysis methods used in the previous two studies to maintain consistency throughout all of these studies and incorporate past study data in our analysis.

\section{Transect Establishment}

The Jenkins study identified transect locations in 2003 by randomly selecting points within a $50 \mathrm{~m}$ wide area that bordered both Smith and Bybee wetlands. They then established 30 transects in the field that began at the water's edge, continuing perpendicularly from the water's edge through the randomly selected point, and ending at an upland location roughly $3.4 \mathrm{~m}$ higher in elevation (Jenkins et al. 2008). This resulted in 30 linear transects that ranged from $21.5 \mathrm{~m}$ to $279.8 \mathrm{~m}$ in length due to topographic differences, and an overall combined length of $3082.9 \mathrm{~m}$. Four of the original 30 transects had to be removed after the first year due to either being accidentally mowed or to surveying errors that occurred. Therefore, the Farrelly study only examined 26 of the original 30 transects (Farelly 2009). We were forced to removed one additional transect from our study after we confirmed that a substantial portion of the transect, including the upland end point, was located beneath a large tree that had recently fallen in that location. Therefore, our surveys and analysis were conducted on 25 transects in total (Figure 1). 


\section{Data Collection}

\section{Water Level Data}

SBW water level data were collected from two primary sources. Weekly readings were taken from a staff gauge that was located on the wetland side of the WCS while the structure was actively retaining water in the wetlands via stop logs (Figure 3). Daily water levels were estimated assuming a linear trend between weekly readings. Daily averages of hourly readings from an Army Corps of Engineers gauge located on the Columbia River main stem were used for periods when the stops logs were completely removed from the WCS and water levels within SBW were driven solely by the Columbia River (USACOE 2017). A combination of these two sources were used for years when the WCS was actively retaining water in SBW during a portion of the year (2004 - 2014). However, the USACOE gauge data were used for the entirety of the 2015 and 2016 water years due to the WCS remaining open during this period of time.

We obtained additional water level data for SBW water levels prior to the installation of the WCS from readings of an old gauge that was located on the Bybee side of the wetlands near where the WCS is now located. This dataset contained readings from 1997 up to when the earthen dam was removed and replaced by the WCS in December 2003. Daily water levels were estimated assuming a linear trend between sample dates, and all years were averaged together to estimate an average yearly water level within SBW when the earthen dam was retaining water within the system year round.

\section{Vegetation Surveys}

We applied the line intercept method used in both the Jenkins and the Farrelly studies to survey vegetation along all 25 transects (Brower et al. 1997). We stretched a 50m tape between rebar stakes along each transect and used a plum line and GRS densitometer (allows the user to view canopy cover at a specific point) to identify all living vegetation that 
intersected each survey point. Vegetation was identified to the species level whenever possible. We recorded vegetation to the genus level only if we could not identify the exact species $(0.5 \%$ of total observations in 2015-2016).

Both the Jenkins and the Farrelly studies surveyed transects at an $0.1 \mathrm{~m}$ interval, which we used for all 2016 vegetation surveys as well. However, due to a late start to the field season in 2015 , we used an $0.5 \mathrm{~m}$ interval for all vegetation surveys that year to insure that all transects could be surveyed before the usual seasonal rainfall inundated them. In the 2016 field season, above average rainfall beginning in late October resulted in seven transects that were inundated partially before the vegetation surveys could be conducted. In these instances, we surveyed from the water's edge to the upland end of each transect. The datasets from the previous two studies were modified to reflect these differences and these modifications are described in detail in the data analysis section.

\section{Elevation Surveys}

All elevation data were collected using the same methods and procedures used in both the Jenkins (2005) and the Farrelly (2012) studies, which are the methods described in Herubin (1982) for differential and profile leveling. Measurements were taken using a Topcon AT-G2 autolevel (Precision Instruments, Portland, OR), tripod, and survey rod. Level circuits were run to transects from known elevation benchmarks located within or near the perimeter of SBW, or from temporary benchmarks established within a level circuit, and all loops were closed within $0.10 \mathrm{ft}(0.25 \mathrm{~cm})$. All measurements were recorded to the nearest $0.005 \mathrm{ft}(1.5 \mathrm{~mm})$. Transect lengths were then measured at 3 meter intervals, with smaller intervals used in areas with pronounced elevation changes. Each $0.1 \mathrm{~m}$ point between measurements was interpolated assuming a linear trend between measurements to determine a topographic profile of each transect.

Above-average rainfall throughout the 2016 field season led to only a subset of 9 of the 
total 25 transects being surveyed and analyzed for elevation data. These transects were chosen in an attempt to represent a wide geographic and elevation range to best compare to the Jenkins (2005) and Farrelly (2012) studies. Summary statistics and a frequency analysis were conducted on this subset of transects to determine average elevation change. Most of the observed changes in elevation over time were less than the margin of error used in this study $( \pm 0.15 \mathrm{ft}, 0.05 \mathrm{~m})$, indicating that there were not substantial changes in elevation. A subset of transects displayed an above average change in elevation between 2003 and 2009; however, that change was not observed in the 2009 to 2016 comparison. Additional inconsistencies found when examining the relationship between these substantial changes led us to conclude that these above average changes were likely related to potential surveying error. The Farrelly (2012) elevation dataset was used for all elevation related analysis due to all the observed changes in elevation between 2009 and 2016 being less than the margin of error of this study.

\section{Phenological Data}

The Farrelly study conducted an extensive investigation into the phenological characteristics of many of the most common species that occur within SBW to best understand how seasonal hydrologic fluctuations may affect species growth (Farrelly 2012). We updated this dataset to reflect additional information or changes that have occurred since this original dataset was created. Our additional research and updates were primarily focused on the most common species on site, specifically any species that had $\geq 5 \%$ cover in at least one monitoring year (Table 1). 
Table 2: Phenological Characteristic of Common Species.

Characteristics for all species with $\geq 5 \%$ cover in at least one monitoring year. Black bars represent data strongly supported by literature and local experts for the Pacific Northwest area. Grey bars represent data supported by fewer and/or non-regional sources. Life cycle and wetland status for vegetation that was only identified to the genus level was assigned based on common local species and expert opinion. Please see Appendix $C$ for a comprehensive list of all plant species found at Smith and Bybee during this study.

\begin{tabular}{|c|c|c|c|c|c|c|c|c|c|c|c|c|c|c|c|}
\hline Species & Life Cycle & $\begin{array}{c}\text { Wetland } \\
\text { Status }\end{array}$ & & Jan & Feb & Mar & Apr & May & June & July & Aug & Sept & Oct & Nov & Dec \\
\hline \multirow{2}{*}{ Persicaria sp. } & \multirow{2}{*}{ Perennial } & \multirow{2}{*}{ OBL } & Vegetative & & & & & & & & & & & & \\
\hline & & & Flowering & & & & & & & & & & & & \\
\hline \multirow{2}{*}{ Phalaris arundinacea } & \multirow{2}{*}{ Perennial } & \multirow{2}{*}{ FACW } & Vegetative & & & & & & & & & & & & \\
\hline & & & Flowering & & & & & & & & & & & & \\
\hline \multirow{2}{*}{ Bindens cernua } & \multirow{2}{*}{ Annual } & \multirow{2}{*}{$\mathrm{OBL}$} & Vegetative & & & & & & & & & & & & \\
\hline & & & Flowering & & & & & & & & & & & & \\
\hline \multirow{2}{*}{ Eragrostis hypnoides } & \multirow{2}{*}{ Annual } & \multirow{2}{*}{ OBL } & Vegetative & & & & & & & & & & & & \\
\hline & & & Flowering & & & & & & & & & & & & \\
\hline \multirow{2}{*}{ Eleocharis palustris } & \multirow{2}{*}{ Perennial } & \multirow{2}{*}{$\mathrm{OBL}$} & Vegetative & & & & & & & & & & & & \\
\hline & & & Flowering & & & & & & & & & & & & \\
\hline \multirow{2}{*}{ Salix lucidia lasiandra } & \multirow{2}{*}{ Perennial } & \multirow{2}{*}{ FACW } & Vegetative & & & & & & & & & & & & \\
\hline & & & Flowering & & & & & & & & & & & & \\
\hline \multirow{2}{*}{ Ludwigia palustris } & \multirow{2}{*}{ Perennial } & \multirow{2}{*}{ OBL } & Vegetative & & & & & & & & & & & & \\
\hline & & & Flowering & & & & & & & & & & & & \\
\hline \multirow{2}{*}{ Cyperus sp. } & \multirow{2}{*}{$\begin{array}{c}\text { Annual/ } \\
\text { Perennial }\end{array}$} & \multirow{2}{*}{$\mathrm{OBL} / \mathrm{FACW}$} & Vegetative & & & & & & & & & & & & \\
\hline & & & Flowering & & & & & & & & & & & & \\
\hline \multirow{2}{*}{ Veronica sp } & \multirow{2}{*}{ Unknown } & \multirow{2}{*}{ Unknown } & Vegetative & $*$ & $*$ & $*$ & $*$ & No & Data & Availa & able & $*$ & $*$ & $*$ & $*$ \\
\hline & & & Flowering & & & & & & & & & & & & \\
\hline
\end{tabular}

References: Timson 1964, Mitchell 1976, Barclay and Crawford 1982, Keddy and Ellis 1984, Sain et al. 1984, Lefor 1987, Carter and Grace 1990, Rice and Pinkerton 1993, Sultan and Bazzaz 1993, Coops and van der Velde 1995, Guard 1995, Galatowitsch and van der Valk 1996, Coops et al. 1996, Weiher et al. 1996, Cooke 1997, Katterer and Andren 1999, Kilbride and Paveglio 1999, Molofsky et al. 1999, Partridge 2001, Stannard and Crowder 2001, Crawford 2003, DiTomaso and Healy 2003, Kuzovkina-Eischen 2003, Miller and Zedler 2003, Christy 2004, Kercher and Zedler 2004, Lavergne and Molofsky 2004, Fraser and Karnezis 2005, Timoney and Argus 2006, Gratani et al. 2008, Jenkins et al. 2008, Gratani et al. 2009, Nygaard and Ejrnaes 2009, Farrelly 2012, Greet et al. 2013, UC/JEPS 2017. 


\section{Data Analysis}

We conducted our analysis using our field data as well as the data collected during the previous two studies (Jenkins et al. 2008, Farrelly 2012). Due to differences in the data collection process that occurred in this study, we had to adjust the past datasets to correlate with our field data. For the 2015 dataset, we isolated all meter and half-meter points along each transect to match the $0.5 \mathrm{~m}$ sampling scale we used that year. This dataset is referred to as the ' $0.5 \mathrm{~m}$ ' dataset in all further analysis. For the 2016 dataset, we used all the data from previous monitoring years for all transects that were fully surveyed in $2016(n=18)$. This dataset is referred to as the ' $0.1 \mathrm{~m}$ Full' dataset in all further analysis. For the subset of transects that were only partially surveyed in 2016 due to inundation $(n=7)$ we only used the corresponding portions of those transects from the previous monitoring years. This dataset is referred to as the ' $0.1 \mathrm{~m}$ Part' dataset in all further analysis.

\section{Water Level Management}

We determined maximum inundation and duration of flooding for all transects in each study year by subtracting transect elevations from water elevations. These calculations excluded all Smith Lake transect elevations below the elevation of known beaver dams on the Smith Lake side of the study area since the dams were established prior to 2009 . This is due to our gauge being located downstream of the beaver dams and therefore unable to capture water level variation in Smith Lake below this elevation. The Farrelly study surveyed a beaver dam in 2009 at $7.51 \mathrm{ft}(2.29 \mathrm{~m})$ (NGVD 1929), and a separate survey of the channel done in 2016 surveyed a beaver dam to be 6.06ft (1.85m) (NGVD 1929).

We generated annual hydrographs for all water years since the WCS was installed (2004 to 2016) and noted the elevations of both the WCS and known beaver dams located on the Smith Lake side of the inter-lakes channel. We also generated average hydrographs of interannual water levels for years prior to the WCS being installed, the period between the 
Jenkins and Farrelly studies (2004-2009), the post-Farrelly period that the water control structure was active (2010-2014), and the two years that the structure was inactive (2015-2016).

We examined the difference in water levels between the SBW gauge and the Columbia River gauge when the WCS was active to examine how much water was being retained in comparison to what water levels would be without active water management. To do so we integrated the total area under the curve for the annual hydrographs we had created and annual hydrographs of the Columbia River gauge to determine the difference between the two. We also divided that total difference by the number of days that the structure was active to determine the average difference per day.

\section{Diversity}

We calculated species diversity using Shannon's diversity index $\left(\mathrm{H}^{\prime}\right)$. Diversity was calculated for the entire site, and both Smith and Bybee in isolation to determine potential differences between the wetlands. Diversity was also calculated in all three of these scenarios after removing monocultures of Phalaris or Persicaria to determine diversity outside of these dominant plant communities. This was done by calculating $\mathrm{H}^{\prime}$ after removing points along every transect that were only populated by either Phalaris or Persicaria (Farrelly 2012). The Hutcheson t-test was then used to determine if there had been a significant change in diversity since 2003 for every subsequent monitoring year (Hutcheson 1970).

Phalaris and Persicaria overall percent cover were then compared to species diversity to determine if there was a relationship between these dominant species and overall species diversity. H' values were compared to the percent cover of both Phalaris and Persicaria using Spearman's rank correlation rho. This was done for the entire site and both Smith and Bybee wetlands in isolation. This was also done after removing any transects with $>80 \%$ Phalaris or Persicaria cover to examine any potential influence monocultures of these two species have on diversity. 
We also examined diversity among only native vegetation to assess how native species in particular are responding over time to the water management regime (Kidd and Yeakley 2015). We identified the status of every known species found in all monitoring years (Jaster et al. 2017). Any species that was identified as non-native $(n=33)$ and plants that were only able to be identified to the genus $(n=15)$ were excluded from this analysis. $H$ ' values were then calculated for the remaining native species $(n=47)$ for every study year. Dominance diversity curves were created and species richness was calculated both for all species and for native species only to determine if either species abundance or evenness was the driving factor behind differences in native and all species diversity.

\section{Percent Cover Change}

We determined percent cover of species by dividing the total number of points along all transects in which each species was present by the total number of points along the transects. This was done for all years of the study within all three datasets. Species that had $\geq 5 \%$ cover in at least one monitoring year were summarized, and we determined significant changes in those species since project initiation using the McNemar's nonparametric test for significant changes (Zar 1998).

\section{Percent Cover Change by Elevation and Inundation}

Percent cover was calculated based on elevation for 2003, 2009, and 2016 to determine changes in overall species cover across the elevation gradient over time by summing the total number of occurrences each species had per $0.1 \mathrm{ft}(0.03 \mathrm{~m})$ in elevation along every transect for all monitoring years. This analysis was only carried out using the $0.1 \mathrm{~m}$ Full and $0.5 \mathrm{~m}$ datasets because the $0.1 \mathrm{~m}$ Part dataset was not representative of the full elevation gradient, and we only reported on the $0.1 \mathrm{~m}$ Full dataset due to the $0.5 \mathrm{~m}$ dataset producing comparably similar results but at a coarser scale. We removed all transect segments located below the elevation of known beaver dams along the Smith Lake channel because these dams impound water below the 
dams' crests, hence any readings taken at the downstream gauge would not accurately represent the current water level within Smith Lake. We removed a marginal amount of the upland end of seven transects located within the Smith wetland from the 2015 and 2016 analysis because herbicide may have been applied in these locations. We then summarized all the individual transect data to examine species presence by elevation across the entire study area.

We investigated cover change by elevation for individual species with $\geq 5 \%$ cover in at least one monitoring. We also included annual maximum inundation and maximum inundation that occurred within only the first two months of each species' growing season in this investigation to examine how water levels may be affecting vegetation.

\section{Percent Cover Change by Wetland Indicator Type and Elevation}

We examined overall shifts in elevation of different wetland indicator types in response to annual variations in hydrology by summarizing changes in cover along the elevation gradient for obligate and facultative wetland species (USACOE 2016). Upland species were excluded due to low presence of these species in our study area. We only looked at all herbaceous, annual species of each wetland indicator type to eliminate any potential interannual water level effects that could be seen in perennial plants. The obligate wetland species we examined were: Eragrostis hypnoides, Rorippa curvisiliqua, Eleocharis ovata, Bidens cernua, Ludwigia palustris, Eleocharis palustris, Ranunculus sceleratus, Myosotis laxa, Azolla mexicana, Eleocharis acicularis, and Cyperus erythrorhizos. The facultative wetland species we examined were: Epilobium ciliatum, Lysimachia nummularia, Bidens frondosa, Pseudognaphalium luteoalbum, Gnaphalium uliginosum, Dipsacus fullonum, Cirsium arvense, Lotus corniculatus, Panicum capillare, Echinochloa crus-galli, Galium aparine, Medicago lupulina, Solanum sp., and Dysphania botrys. 


\section{Dominant Species Interactions}

To best understand how Phalaris and Persicaria were interacting with other species, we examined locations along transects in which Phalaris or Persicaria have replaced species that were present at that point in 2003 , and vice-versa. We determined all the points along each transect in which Phalaris or Persicaria were present in 2003 but no longer present in 2015 and 2016, and which species had replaced them. We also conducted the inverse of that analysis by examining points along each transect that were occupied by Phalaris or Persicaria in 2015 or 2016 but not in 2003 , and what species occupied that point in 2003 . We then summarized those results and created $2 \times 2$ contingency tables showing all points that Phalaris or Persicaria either occupied both in 2003 and 2015 or 2016 , in neither 2003 or 2015/2016, was replaced by another species in 2015 or 2016, or replaced another species in 2015 or 2016 . We then used McNemar's nonparametric test to determine significant changes in species interactions over the years. 


\section{RESULTS}

\section{Water Level Management}

Annual variations in water levels within SBW have been altered significantly by the WCS (Figure 4). The dam that was in place prior to the WCS, which made SBW an isolated system, resulted in a mostly consistent water level throughout the year. Active WCS management led to much higher water levels from winter to mid-summer and substantially lower water levels in the late-summer and fall. Water levels were highest from 2010 to 2012 due to high water elevations in the Columbia River that occasionally overtopped the WCS (Appendix B). The years 20132014 were relatively drier (see Figure B-2). In the most recent years, when the WCS has been left open and water levels have been controlled by the Columbia River (2015-2016), water levels in SBW were characterized by low water levels for late-summer and fall similar to those seen when the WCS was actively managing water levels, but a steady decrease in water levels from winter to mid-summer. These patterns can also be seen in more detail in the yearly hydrographs (Appendix B). 


\section{Averaged Hydrographs}

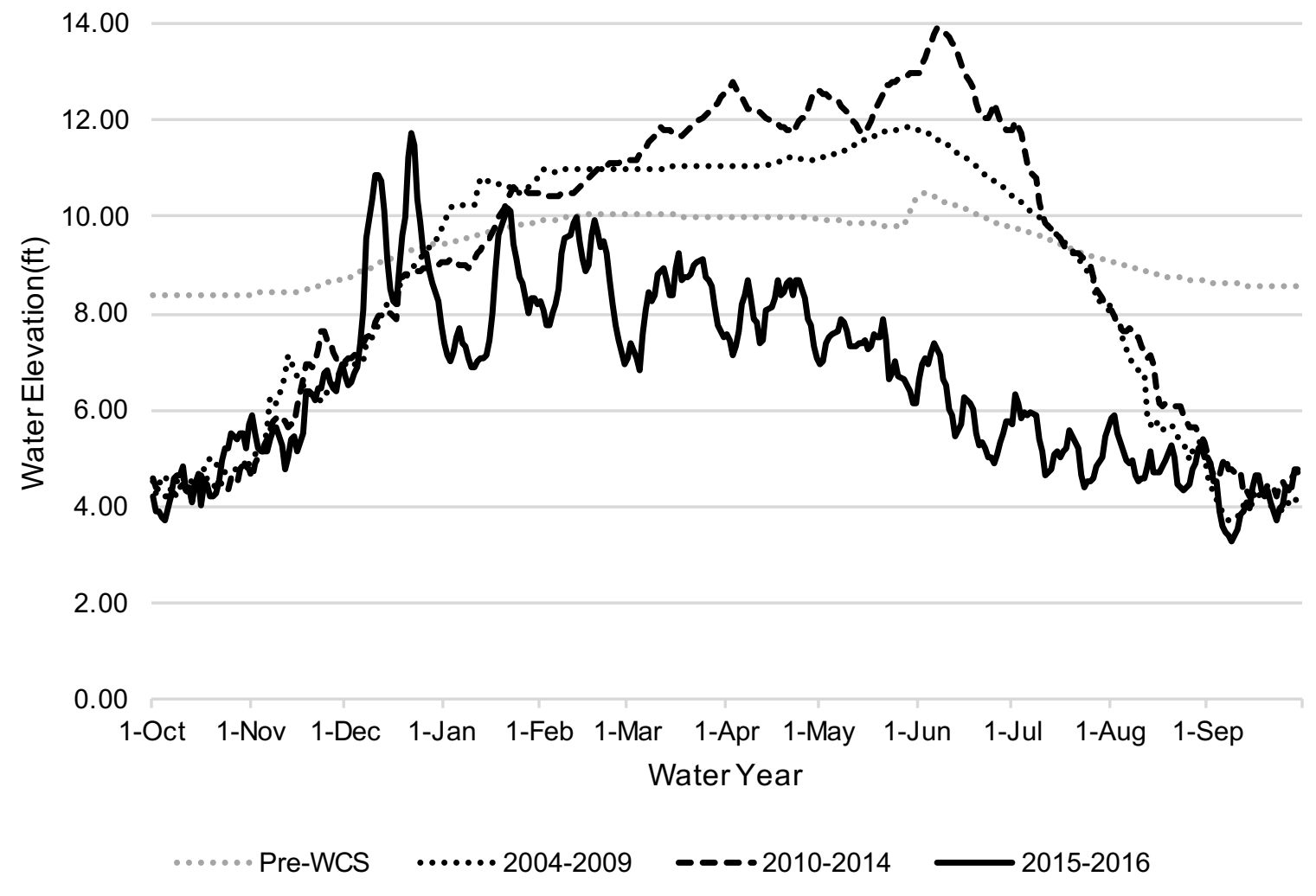

Figure 4: Average Hydrographs.

Interannual hydrographs of significant periods of water management in Smith and Bybee. PreWCS is an average of measurements taken from 1997 to 2003 before the WCS was installed. 2004-2009 is the period of time between the Jenkins and Farrelly studies. 2010-2014 is the period post-Farrelly study that the WCS was active. 2015-2016 represents the two years that the WCS was left open and water levels were controlled solely by Columbia River flow.

Water Elevations Relative to the Columbia River

We also examined SBW water elevations relative to the Columbia River to determine how much water is being retained within SBW compared to current Columbia River hydrology (Figure 2). We observed a reduction in the difference between the elevation of water being retained in SBW compared to water elevations on the Columbia in the years following the Farrelly study (Figure 5). Prior to the Farrelly study (2004-2009) managers were retaining, on average, water elevations that were $2.77 \mathrm{ft}(0.84 \mathrm{~m})$ (NGVD 1929) above the elevation of the 
Columbia River. After the Farrelly study was conducted (2010-2014), average water elevations dropped to $2.25 \mathrm{ft}(0.69 \mathrm{~m})$ above the Columbia River. The years 2010 to 2012 were particularly wet, and SBW experienced multiple instances of water overtopping the WCS, which resulted in no difference in water elevations during those periods (Appendix B). The years 2013 and 2014 were substantially drier for the Columbia, which resulted in a larger difference in water elevations similar to the 2004-2009 period. This accounts for the higher variability and lower median difference seen in the 2010-2014 period.

\section{Smith and Bybee Water Elevations Relative to the Columbia River}

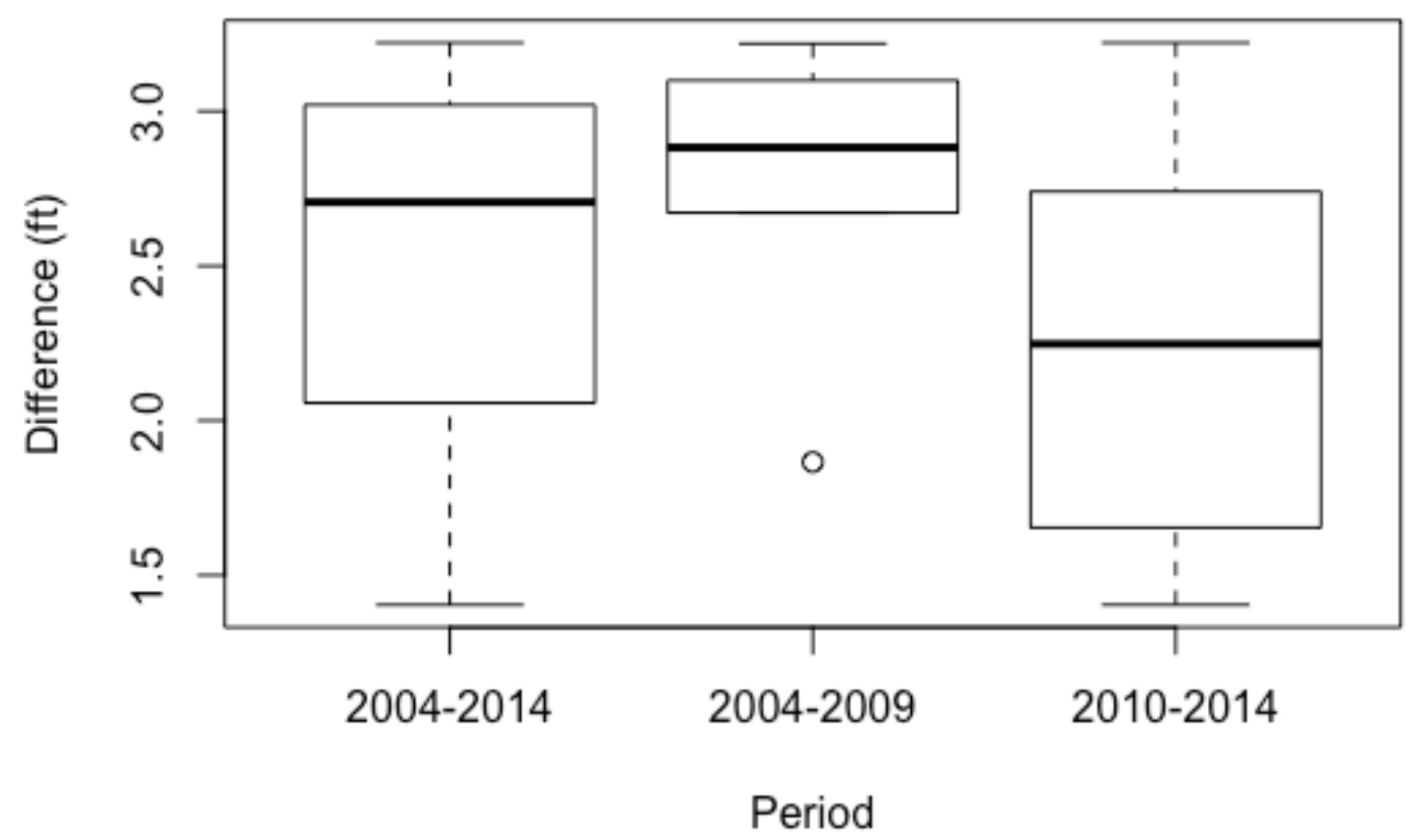

Figure 5: Water Elevations During Active Water Management Relative to the Columbia River. The average difference per day between water elevations recorded at the gauge within Smith and Bybee Wetlands and the ACOE Columbia River main stem gauge during periods when the water control structure was actively managing water levels. Retention periods were 16.5 days longer on average in 2004-2009 (mean 260.5 days) compared to 2009-2014 (mean 244 days). 
We also found a pattern of reduced late-season retention in the years following the Farrelly study. Managers at SBW would gradually lower water levels within the wetlands throughout the summer season until the water control structure was completely open, and the rate of this drawdown was observably faster after 2009. This late-season drawdown process in the years from 2004 to 2009 took, on average, 68.17 days and during that time the water control structure continued to retain a net average of $211.55 \mathrm{ft}(64.48 \mathrm{~m})$ or $3.18 \mathrm{ft} /$ day $(0.97 \mathrm{~m} /$ day $)$ of water. Post-2009 this process only took, on average, 53.60 days and retained $117.91 \mathrm{ft}(35.94 \mathrm{~m})$ or $2.07 \mathrm{ft} /$ day $(0.63 \mathrm{~m} /$ day) of water (Appendix B).

\section{Diversity}

Plant species diversity $\left(H^{\prime}\right)$ declined significantly $(p<0.05)$ overall in the time since 2003 across our entire study area, and within Smith and Bybee wetlands in isolation. This includes diversity of species in locations outside of monocultures of Phalaris or Persicaria (Table 2). The only H' value that did not differ significantly from 2003 was the Smith Lake subset of the 2016 partial transect dataset. However, diversity in that area had increased significantly in 2008 and 2009, and has since declined back down to nearly where it was in 2003.

Diversity throughout the site was mainly driven by a small number of plants relative to the total number of observed species each year as seen in the dominance/diversity curves (Figure 6). The heavily skewed shape of these graphs suggest that the most dominant species have an unevenly large impact, in particular the two co-dominant species of Phalaris and Persicaria. Phalaris had a significant negative relationship to diversity in both 2003 and 2004 (Table 3). Persicaria had a significant negative relationship with diversity in 2015 and 2016 (Table 3). However, most of the significant negative relationships between $\mathrm{H}^{\prime}$ and percent cover were no longer significant after all transects with $>80 \%$ cover of either Phalaris or Persicaria 
were removed. The only results that were still significant for Phalaris were from 2003 in the $0.5 m$ and $0.1 m$ Full datasets (Spearmans's rho $=-0.53, p<0.05$ and Spearman's rho $=-0.56, p<$ 0.05 respectively). The only significant relationship for Persicaria was in 2015 (Spearmen's rho $=-0.51, p<0.05)$.

Table 2: Overall Species Diversity.

Shannon's diversity $\left(\mathrm{H}^{\prime}\right)$ values ( \pm 1 standard deviation) for every monitoring year for the entire study site (all transects), and for the subset of transects located within each wetland. $H^{\prime}$ values were calculated for the entire length of each transect as well as the portions of each transect outside of monocultures of either Phalaris or Persicaria). Significant differences $(p<0.05)$ in $\mathrm{H}^{\prime}$ from 2003 are denoted via bold values.

\begin{tabular}{|c|c|c|c|c|c|}
\hline \multicolumn{6}{|c|}{ Shannon's Diversity (H') } \\
\hline \multicolumn{6}{|c|}{$\underline{0.5 \mathrm{~m} \text { Dataset }}$} \\
\hline & 2003 & 2004 & 2008 & 2009 & 2015 \\
\hline & \multicolumn{5}{|c|}{ Entire Population } \\
\hline All Transects & $2.61( \pm 0.01)$ & $2.58( \pm 0.01)$ & $2.65( \pm 0.01)$ & $2.5( \pm 0.01)$ & $2.3( \pm 0.01)$ \\
\hline Smith Only & $2.64( \pm 0.02)$ & $2.56( \pm 0.02)$ & $2.65( \pm 0.01)$ & $2.4( \pm 0.02)$ & $2.32( \pm 0.02)$ \\
\hline \multirow[t]{2}{*}{ Bybee Only } & $2.42( \pm 0.02)$ & $2.48( \pm 0.02)$ & $2.55( \pm 0.01)$ & $2.42( \pm 0.02)$ & $2.01( \pm 0.02)$ \\
\hline & \multicolumn{5}{|c|}{ Outside Monocultures } \\
\hline All Transects & $2.83( \pm 0.01)$ & $2.72( \pm 0.01)$ & $2.7( \pm 0.01)$ & $2.63( \pm 0.01)$ & $2.54( \pm 0.01)$ \\
\hline Smith Only & $2.8( \pm 0.02)$ & $2.66( \pm 0.02)$ & $2.66( \pm 0.02)$ & $2.51( \pm 0.02)$ & $2.47( \pm 0.01)$ \\
\hline Bybee Only & $2.76( \pm 0.02)$ & $2.72( \pm 0.02)$ & $2.62( \pm 0.02)$ & $2.55( \pm 0.02)$ & $2.39( \pm 0.02)$ \\
\hline \multicolumn{6}{|c|}{$\underline{0.1 \mathrm{~m} \text { Full Dataset }}$} \\
\hline & 2003 & 2004 & 2008 & 2009 & 2016 \\
\hline & \multicolumn{5}{|c|}{ Entire Population } \\
\hline All Transects & $2.44( \pm 0.01)$ & $2.5( \pm 0.01)$ & $2.51( \pm 0.01)$ & $2.45( \pm 0.01)$ & $2.1( \pm 0.01)$ \\
\hline Smith Only & $2.47( \pm 0.01)$ & $2.45( \pm 0.01)$ & $2.4( \pm 0.01)$ & $2.23( \pm 0.01)$ & $1.97( \pm 0.01)$ \\
\hline \multirow[t]{2}{*}{ Bybee Only } & $2.2( \pm 0.01)$ & $2.37( \pm 0.01)$ & $2.45( \pm 0.01)$ & $2.38( \pm 0.01)$ & $1.95( \pm 0.01)$ \\
\hline & \multicolumn{5}{|c|}{ Outside Monocultures } \\
\hline All Transects & $2.7( \pm 0.01)$ & $2.7( \pm 0.01)$ & $2.58( \pm 0.01)$ & $2.61( \pm 0.01)$ & $2.41( \pm 0.01)$ \\
\hline Smith Only & $2.54( \pm 0.01)$ & $2.5( \pm 0.01)$ & $2.42( \pm 0.01)$ & $2.37( \pm 0.01)$ & $2.21( \pm 0.01)$ \\
\hline Bybee Only & $2.7( \pm 0.01)$ & $2.73( \pm 0.01)$ & $2.55( \pm 0.01)$ & $2.54( \pm 0.01)$ & $2.36( \pm 0.01)$ \\
\hline \multicolumn{6}{|c|}{$\underline{0.1 \mathrm{~m} \text { Part Dataset }}$} \\
\hline & 2003 & 2004 & 2008 & 2009 & 2016 \\
\hline & \multicolumn{5}{|c|}{ Entire Population } \\
\hline All Transects & $2.58( \pm 0.02)$ & $2.61( \pm 0.01)$ & $2.78( \pm 0.01)$ & $2.51( \pm 0.01)$ & $2.22( \pm 0.01)$ \\
\hline Smith Only & $2.25( \pm 0.02)$ & $2.31( \pm 0.02)$ & $2.68( \pm 0.01)$ & $2.4( \pm 0.01)$ & $2.24( \pm 0.01)$ \\
\hline \multirow[t]{2}{*}{ Bybee Only } & $2.48( \pm 0.02)$ & $2.51( \pm 0.02)$ & $2.55( \pm 0.02)$ & $2.37( \pm 0.02)$ & $1.69( \pm 0.02)$ \\
\hline & \multicolumn{5}{|c|}{ Outside Monocultures } \\
\hline All Transects & $2.91( \pm 0.01)$ & $2.73( \pm 0.01)$ & $2.8( \pm 0.01)$ & $2.59( \pm 0.01)$ & $2.38( \pm 0.01)$ \\
\hline Smith Only & $2.65( \pm 0.02)$ & $2.47( \pm 0.02)$ & $2.7( \pm 0.01)$ & $2.46( \pm 0.01)$ & $2.28( \pm 0.01)$ \\
\hline Bybee Only & $2.49( \pm 0.02)$ & $2.5( \pm 0.02)$ & $2.56( \pm 0.02)$ & $2.45( \pm 0.02)$ & $1.94( \pm 0.03)$ \\
\hline
\end{tabular}


Table 3: Correlation of Dominant Species Presence to Overall Diversity.

Spearman's rank correlation rho values for every monitoring year for the entire study site (all transects), and for each wetland (Smith and Bybee). These values represent the relationship between $\mathrm{H}^{\prime}$ and percent cover of both Phalaris and Persicaria (range -1 to 1 , negative values indicate a negative relationship, positive values indicate a positive relationship). Significant relationships $(p<0.05)$ are denoted in bold.

\begin{tabular}{|c|c|c|c|c|c|}
\hline \multicolumn{6}{|c|}{ Spearman's Rank Correlation Rho } \\
\hline \multicolumn{6}{|c|}{$\underline{0.5 \mathrm{~m} \text { Dataset }}$} \\
\hline & 2003 & 2004 & 2008 & 2009 & 2015 \\
\hline & \multicolumn{5}{|c|}{ H' vs Reed Canarygrass } \\
\hline All Transects & -0.68 & -0.61 & -0.25 & -0.13 & -0.08 \\
\hline Smith Only & -0.47 & -0.58 & -0.19 & -0.50 & 0.30 \\
\hline \multirow[t]{2}{*}{ Bybee Only } & -0.79 & -0.75 & -0.30 & 0.01 & 0.24 \\
\hline & \multicolumn{5}{|c|}{ H' vs Smartweed } \\
\hline All Transects & 0.05 & 0.04 & -0.49 & -0.46 & -0.68 \\
\hline Smith Only & -0.40 & -0.17 & -0.90 & -0.80 & -0.80 \\
\hline Bybee Only & 0.32 & 0.10 & -0.08 & -0.45 & -0.62 \\
\hline \multicolumn{6}{|c|}{$0.1 \mathrm{~m}$ Full Dataset } \\
\hline & 2003 & 2004 & 2008 & 2009 & 2016 \\
\hline & \multicolumn{5}{|c|}{ H' vs Reed Canarygrass } \\
\hline All Transects & -0.79 & -0.67 & -0.11 & -0.17 & -0.17 \\
\hline Smith Only & -0.64 & -0.77 & -0.36 & -0.82 & 0.50 \\
\hline \multirow[t]{2}{*}{ Bybee Only } & -0.87 & -0.77 & -0.25 & -0.24 & -0.03 \\
\hline & \multicolumn{5}{|c|}{ H' vs Smartweed } \\
\hline All Transects & 0.22 & 0.31 & -0.31 & -0.27 & -0.70 \\
\hline Smith Only & 0.07 & 0.36 & -0.71 & -0.61 & -0.57 \\
\hline Bybee Only & 0.29 & 0.35 & 0.04 & -0.37 & -0.75 \\
\hline \multicolumn{6}{|c|}{$0.1 \mathrm{~m}$ Part Dataset } \\
\hline & 2003 & 2004 & 2008 & 2009 & 2016 \\
\hline & \multicolumn{5}{|c|}{ H' vs Reed Canarygrass } \\
\hline All Transects & -0.54 & -0.57 & -0.21 & -0.29 & 0.19 \\
\hline Smith Only & -0.40 & -0.40 & -0.20 & -0.40 & 0.31 \\
\hline Bybee Only & -1.00 & -1.00 & 1.00 & 1.00 & 1.00 \\
\hline & \multicolumn{5}{|c|}{ H' vs Smartweed } \\
\hline All Transects & 0.36 & -0.18 & -0.71 & -0.93 & -0.75 \\
\hline Smith Only & 0.10 & -0.30 & -0.70 & -0.90 & -0.60 \\
\hline Bybee Only & 1.00 & 1.00 & -1.00 & -1.00 & -1.00 \\
\hline
\end{tabular}


When we analyzed the diversity of native species only and compared that to overall diversity, we found native species diversity to be less than overall diversity, and the decrease in native diversity over time was not as great as the decrease in overall diversity (Table 4). This pattern occurred in all three datasets for the entire study site, and in both Smith and Bybee in isolation. The relative evenness of native species and all species are quite similar for all monitoring years (Figure 6). However, native species richness did not vary much over time, whereas all species richness decreased much more over time (Table 5).

The decrease in richness we observed was not simply the result of some species dropping out of the system over time, but a combination of species dropping out and other species being recruited (Appendix C). Between 2003 and 2009, 26 species dropped out and 15 were recruited. By 2016, 30 species had dropped out of the system since 2003 and 23 had been recruited. Only 20 species that were observed in 2003 were also observed in 2016, a majority of which were perennial native species. The percentage of species that are native and non-native has not changed substantially over the years, despite these shifts in community composition (Table 6). The decline in overall species richness has been due to a decline in both native and non-native species, as well as species whose native status was unknown. However, the composition of species of different wetland indicator types has shifted over the years, driven primarily by an increase in the percentage of obligate wetland species (Table 6). 
Table 4: Native Species Diversity.

Shannon's diversity $\left(H^{\prime}\right)$ values ( \pm 1 standard deviation) of only native species found for every monitoring year, and all species combined, as well as the overall change in diversity since 2003. Bold values indicate a significant change $(p<0.05)$ from 2003.

\begin{tabular}{|c|c|c|c|c|c|c|c|c|c|}
\hline \multicolumn{10}{|c|}{ All Transects: Overall Diversity of All Species vs Native Species Only } \\
\hline \multirow[b]{2}{*}{ Year } & \multicolumn{5}{|c|}{ Shannon's Diversity Index (H') } & \multicolumn{4}{|c|}{ Change in Diversity Since 2003} \\
\hline & 2003 & 2004 & 2008 & 2009 & $2015 / 16$ & 2004-2003 & $2008-2003$ & $2009-2003$ & 2015/16-2003 \\
\hline & \multicolumn{9}{|c|}{$0.5 \mathrm{~m}$} \\
\hline Natives Only & $2.13( \pm 0.01)$ & $2.18( \pm 0.02)$ & $2.09( \pm 0.02)$ & $1.94( \pm 0.02)$ & $1.97( \pm 0.01)$ & 0.05 & -0.04 & -0.20 & -0.17 \\
\hline \multirow[t]{2}{*}{ All Species } & $2.61( \pm 0.01)$ & $2.58( \pm 0.01)$ & $2.65( \pm 0.01)$ & $2.5( \pm 0.01)$ & $2.3( \pm 0.01)$ & -0.03 & 0.04 & -0.11 & -0.31 \\
\hline & \multicolumn{9}{|c|}{$0.1 \mathrm{~m}$ Full } \\
\hline Natives Only & $2.0( \pm 0.01)$ & $2.12( \pm 0.01)$ & $1.95( \pm 0.01)$ & $1.85( \pm 0.01)$ & $1.71( \pm 0.01)$ & 0.12 & -0.05 & -0.15 & -0.29 \\
\hline \multirow[t]{2}{*}{ All Species } & $2.44( \pm 0.01)$ & $2.5( \pm 0.01)$ & $2.51( \pm 0.01)$ & $2.45( \pm 0.01)$ & $2.1( \pm 0.01)$ & 0.06 & 0.07 & 0.01 & -0.34 \\
\hline & \multicolumn{9}{|c|}{$0.1 \mathrm{~m}$ Part } \\
\hline Natives Only & $2.25( \pm 0.02)$ & $2.26( \pm 0.01)$ & $2.27( \pm 0.01)$ & $2.06( \pm 0.01)$ & $1.79( \pm 0.01)$ & 0.01 & 0.01 & -0.19 & -0.46 \\
\hline All Species & $2.58( \pm 0.02)$ & $2.61( \pm 0.01)$ & $2.78( \pm 0.01)$ & $2.51( \pm 0.01)$ & $2.22( \pm 0.01)$ & 0.03 & 0.20 & -0.07 & -0.36 \\
\hline \multicolumn{10}{|c|}{ Smith Lake: Overall Diversity of All Species vs Native Species Only } \\
\hline & \multicolumn{5}{|c|}{ Shannon's Diversity Index ( $\left.\mathrm{H}^{\prime}\right)$} & \multicolumn{4}{|c|}{ Change in Diversity Since 2003} \\
\hline \multirow[t]{2}{*}{ Year } & 2003 & 2004 & 2008 & 2009 & 2015/16 & 2004-2003 & $2008-2003$ & $2009-2003$ & $2015 / 16-2003$ \\
\hline & \multicolumn{9}{|c|}{$0.5 \mathrm{~m}$} \\
\hline Natives Only & $2.13( \pm 0.02)$ & $2.10( \pm 0.02)$ & $2.08( \pm 0.02)$ & $1.88( \pm 0.02)$ & $2.0( \pm 0.02)$ & -0.04 & -0.05 & -0.25 & -0.13 \\
\hline \multirow[t]{2}{*}{ All Species } & $2.64( \pm 0.02)$ & $2.56( \pm 0.02)$ & $2.65( \pm 0.01)$ & $2.4( \pm 0.02)$ & $2.32( \pm 0.02)$ & -0.08 & 0.01 & -0.24 & -0.32 \\
\hline & \multicolumn{9}{|c|}{$0.1 \mathrm{~m}$ Full } \\
\hline Natives Only & $1.93( \pm 0.01)$ & $1.92( \pm 0.01)$ & $1.87( \pm 0.02)$ & $1.65( \pm 0.01)$ & $1.68( \pm 0.01)$ & -0.01 & -0.06 & -0.28 & -0.25 \\
\hline \multirow[t]{2}{*}{ All Species } & $2.47( \pm 0.01)$ & $2.45( \pm 0.01)$ & $2.4( \pm 0.01)$ & $2.23( \pm 0.01)$ & $1.97( \pm 0.01)$ & -0.03 & -0.08 & -0.25 & -0.50 \\
\hline & \multicolumn{9}{|c|}{$0.1 \mathrm{~m}$ Part } \\
\hline Natives Only & $2.06( \pm 0.02)$ & $2.04( \pm 0.02)$ & $2.11( \pm 0.02)$ & $2.03( \pm 0.01)$ & $1.88( \pm 0.01)$ & -0.03 & 0.05 & -0.03 & -0.19 \\
\hline All Species & $2.25( \pm 0.02)$ & $2.31( \pm 0.02)$ & $2.68( \pm 0.01)$ & $2.4( \pm 0.01)$ & $2.24( \pm 0.01)$ & 0.06 & 0.43 & 0.16 & -0.01 \\
\hline \multicolumn{10}{|c|}{ Bybee Lake: Overall Diversity of All Species vs Native Species Only } \\
\hline & \multicolumn{5}{|c|}{ Shannon's Diversity Index (H') } & \multicolumn{4}{|c|}{ Change in Diversity Since 2003} \\
\hline \multirow[t]{2}{*}{ Year } & 2003 & 2004 & 2008 & 2009 & $2015 / 16$ & $2004-2003$ & $2008-2003$ & $2009-2003$ & $2015 / 16-2003$ \\
\hline & \multicolumn{9}{|c|}{$0.5 \mathrm{~m}$} \\
\hline Natives Only & $2.01( \pm 0.03)$ & $2.20( \pm 0.02)$ & $2.0( \pm 0.02)$ & $1.86( \pm 0.03)$ & $1.66( \pm 0.03)$ & 0.19 & -0.01 & -0.15 & -0.35 \\
\hline \multirow[t]{2}{*}{ All Species } & $2.42( \pm 0.02)$ & $2.48( \pm 0.02)$ & $2.55( \pm 0.01)$ & $2.42( \pm 0.02)$ & $2.01( \pm 0.02)$ & 0.06 & 0.13 & 0.00 & -0.41 \\
\hline & \multicolumn{9}{|c|}{$0.1 \mathrm{~m}$ Full } \\
\hline Natives Only & $2.03( \pm 0.02)$ & $2.24( \pm 0.01)$ & $1.85( \pm 0.01)$ & $1.90( \pm 0.01)$ & $1.57( \pm 0.01)$ & 0.21 & -0.18 & -0.13 & -0.46 \\
\hline \multirow[t]{2}{*}{ All Species } & $2.2( \pm 0.01)$ & $2.37( \pm 0.01)$ & $2.45( \pm 0.01)$ & $2.38( \pm 0.01)$ & $1.95( \pm 0.01)$ & 0.17 & 0.24 & 0.17 & -0.25 \\
\hline & & & & & $0.1 \mathrm{~m}$ Part & & & & \\
\hline Natives Only & $1.65( \pm 0.03)$ & $1.97( \pm 0.02)$ & $2.02( \pm 0.02)$ & $1.76( \pm 0.03)$ & $1.16( \pm 0.03)$ & 0.32 & 0.37 & 0.11 & -0.49 \\
\hline All Species & $2.48( \pm 0.02)$ & $2.51( \pm 0.02)$ & $2.55( \pm 0.02)$ & $2.37( \pm 0.02)$ & $1.69( \pm 0.02)$ & 0.04 & 0.07 & -0.11 & -0.79 \\
\hline
\end{tabular}


Table 5: Species Richness vs Diversity.

Species richness and diversity $\left(H^{\prime}\right)$ values ( \pm 1 standard deviation) for all years, as well as changes in those values since 2003 , for all species and native species only across all three datasets. Note the relatively small drop in native species vs all species.

\begin{tabular}{|c|c|c|c|c|c|c|c|c|c|c|}
\hline \multicolumn{7}{|c|}{ Overall Richness and Diversity of All Species vs Native Species Only } & \multicolumn{4}{|c|}{ Change in Diversity Since 2003} \\
\hline & Year & 2003 & 2004 & 2008 & 2009 & $2015 / 16$ & $2004-2003$ & $2008-2003$ & $2009-2003$ & $2015 / 16-2003$ \\
\hline & & \multicolumn{9}{|c|}{$0.5 \mathrm{~m}$} \\
\hline \multirow{2}{*}{ Richness } & Natives & 25 & 27 & 22 & 20 & 23 & 2 & -3 & -5 & -2 \\
\hline & All & 45 & 42 & 39 & 34 & 37 & -3 & -6 & -11 & -8 \\
\hline \multirow{3}{*}{ Diversity (H') } & Natives & $2.13( \pm 0.01)$ & $2.18( \pm 0.02)$ & $2.09( \pm 0.02)$ & $1.94( \pm 0.02)$ & $1.97( \pm 0.01)$ & 0.05 & -0.04 & -0.20 & -0.17 \\
\hline & All & $2.61( \pm 0.01)$ & $2.58( \pm 0.01)$ & $2.65( \pm 0.01)$ & $2.5( \pm 0.01)$ & $2.3( \pm 0.01)$ & -0.03 & 0.04 & -0.11 & -0.31 \\
\hline & & \multicolumn{9}{|c|}{$0.1 \mathrm{~m}$ Full } \\
\hline \multirow{2}{*}{ Richness } & Natives & 23 & 24 & 20 & 17 & 21 & 1 & -3 & -6 & -2 \\
\hline & All & 41 & 40 & 34 & 34 & 34 & -1 & -7 & -7 & -7 \\
\hline \multirow{3}{*}{ Diversity (H') } & Natives & $2.0( \pm 0.01)$ & $2.12( \pm 0.01)$ & $1.95( \pm 0.01)$ & $1.85( \pm 0.01)$ & $1.71( \pm 0.01)$ & 0.12 & -0.05 & -0.15 & -0.29 \\
\hline & All & $2.44( \pm 0.01)$ & $2.5( \pm 0.01)$ & $2.51( \pm 0.01)$ & $2.45( \pm 0.01)$ & $2.1( \pm 0.01)$ & 0.06 & 0.07 & 0.01 & -0.34 \\
\hline & & \multicolumn{9}{|c|}{$0.1 \mathrm{~m}$ Part } \\
\hline \multirow{2}{*}{ Richness } & Natives & 22 & 23 & 22 & 19 & 20 & 1 & 0 & -3 & -2 \\
\hline & All & 43 & 41 & 37 & 33 & 32 & -2 & -6 & -10 & -11 \\
\hline \multirow{2}{*}{ Diversity ( $\left.\mathrm{H}^{\prime}\right)$} & Natives & $2.25( \pm 0.02)$ & $2.26( \pm 0.01)$ & $2.27( \pm 0.01)$ & $2.06( \pm 0.01)$ & $1.79( \pm 0.01)$ & 0.01 & 0.01 & -0.19 & -0.46 \\
\hline & All & $2.58( \pm 0.02)$ & $2.61( \pm 0.01)$ & $2.78( \pm 0.01)$ & $2.51( \pm 0.01)$ & $2.22( \pm 0.01)$ & 0.03 & 0.20 & -0.07 & -0.36 \\
\hline
\end{tabular}

Table 6: Percent of Species by Native Species and Wetland Indicator Type.

Overall species richness for every monitoring year, and the percentage of all species that were identified as native or non-native and by wetland indicator type.

\begin{tabular}{|r|c|c|c|c|c|c|}
\hline \multicolumn{7}{|c|}{ Relative Richness } \\
\hline & 2003 & 2004 & 2008 & 2009 & 2015 & 2016 \\
\hline $\begin{array}{r}\text { All Species } \\
\text { Richness }\end{array}$ & 50 & 50 & 40 & 39 & 37 & 43 \\
\hline Native & $54 \%$ & $56 \%$ & $58 \%$ & $51 \%$ & $62 \%$ & $58 \%$ \\
\hline Non-native & $34 \%$ & $34 \%$ & $28 \%$ & $33 \%$ & $27 \%$ & $37 \%$ \\
\hline Unknown & $12 \%$ & $8 \%$ & $15 \%$ & $15 \%$ & $11 \%$ & $5 \%$ \\
\hline Obligate & $32 \%$ & $32 \%$ & $40 \%$ & $33 \%$ & $43 \%$ & $42 \%$ \\
\hline Facultative & $48 \%$ & $54 \%$ & $43 \%$ & $46 \%$ & $46 \%$ & $47 \%$ \\
\hline Upland & $0 \%$ & $0 \%$ & $0 \%$ & $0 \%$ & $5 \%$ & $5 \%$ \\
Unknown & $20 \%$ & $14 \%$ & $18 \%$ & $21 \%$ & $5 \%$ & $7 \%$ \\
\hline
\end{tabular}




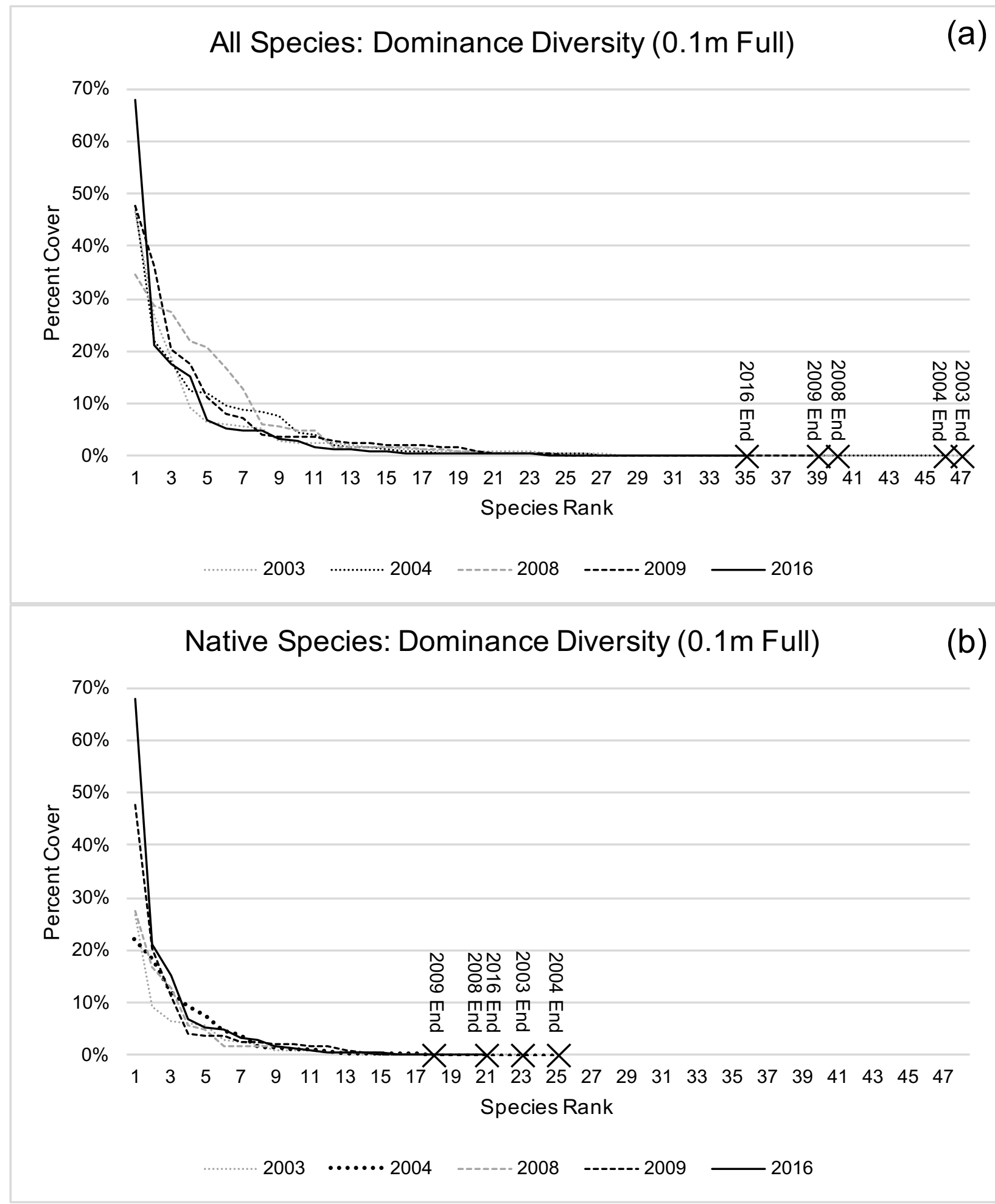

Figure 6: Dominance Diversity Curves for (a) All Species and (b) Native Species Only. Ranked percent cover for each species in every monitoring year. Species rank (x-axis) is a linear ranking from highest to lowest percent cover for all species present in each year. Note that this ranking system is determined by percent cover only and therefore different species could be represented by the same rank in different years. X's indicate the terminal point for each year graphed. 


\section{$\underline{\text { Percent Cover }}$}

\section{Overall Change}

The species with the most substantial cover changes that occurred since project initiation in 2003 were Persicaria and Phalaris. Phalaris was the dominant species on site in 2003 and 2004, but has since experienced a sustained decrease in percent cover (Figure 7a). Persicaria exhibited an inverse pattern compared to Phalaris, replacing it as the dominant species by 2008 and continuing to increase in cover since then (Figure 7b).

A majority of the species we observed were somewhat rare, with only nine species having $\geq 5 \%$ cover in at least one monitoring year, seven of which are native species (Appendix A). Of those nine species, only Phalaris experienced a constant decline in percent cover from 2003 to 2016 across all three of our datasets. Seven species with $\geq 5 \%$ cover, all of which are native species, experienced increased coverage in 2015 and 2016 compared to 2003. Of those seven species, only Salix lucida ssp. lasiandra and Persicaria experienced a continued increase in percent cover for all years (Figure 7b, c). Many species experienced declines in percent cover during at least one intermediate year, and a subsequent increase in cover from then until 2015 or 2016 (Figure 7e, f, g, h). Ludwigia palustris declined in cover since 2003, but experienced a slight increase between 2008 and 2009 (Figure 7d). The Veronica species was the only species that experienced $\geq 5 \%$ cover in previous years, but was not observed at all in 2015 or 2016 (Figure 7i). Full plant community composition for all years of the study is provided in Appendix C. 


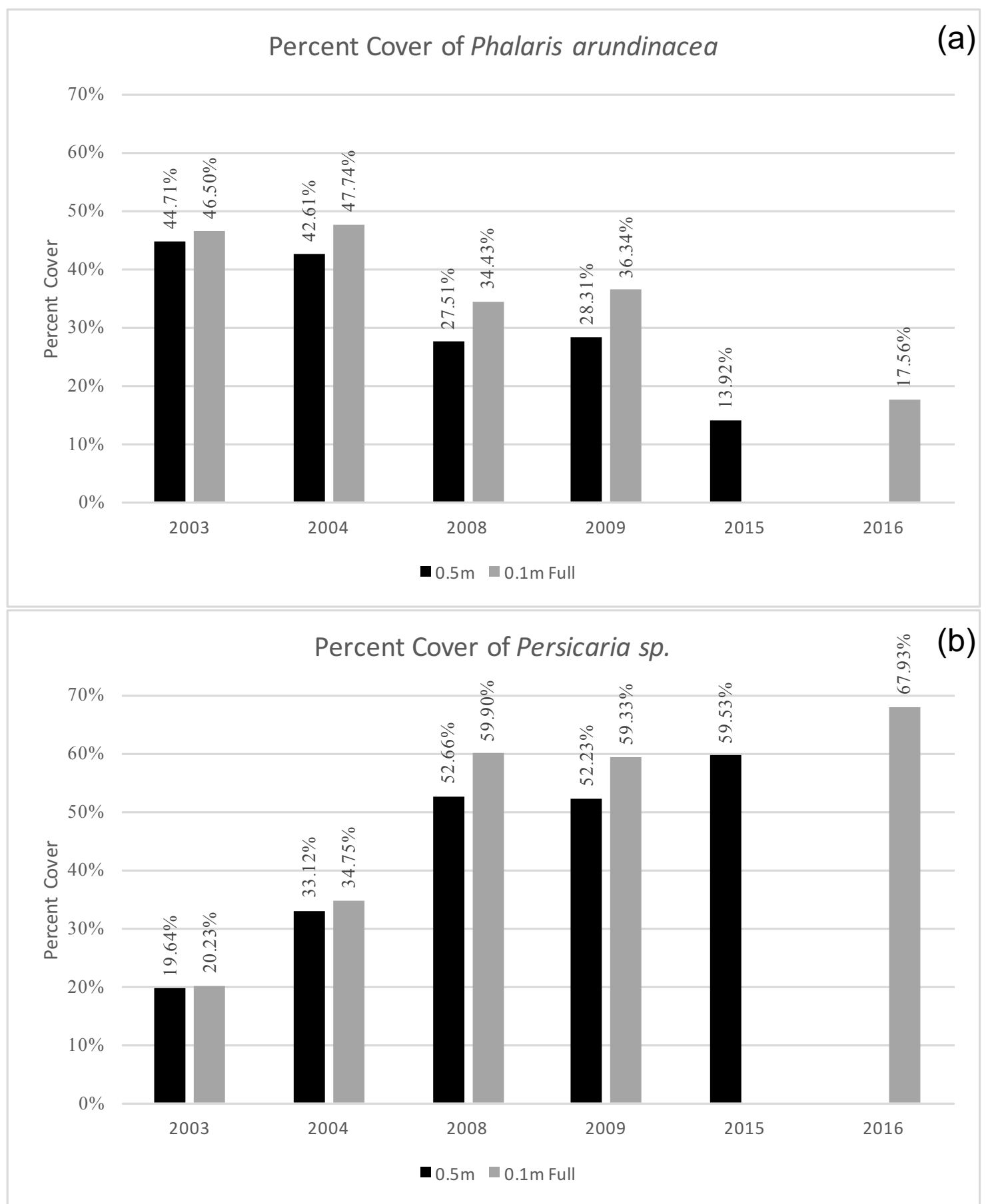

Figure 7: Major Percent Cover Changes.

Percent cover in each monitoring year for all species with $\geq 5 \%$ cover in at least one monitoring year. Y-axis values are adjusted to allow for comparison between species with similar total percent cover. Panels show (a) Phalaris arundinacea (b) Persicaria sp. (c) Salix Iucidia lasiandra (d) Ludwigia palustris (e) Bidens cernua (f) Eragrostis hypnoides (g) Eleocharis palustris (h) Cyperus sp. and (i) Veronica sp. 


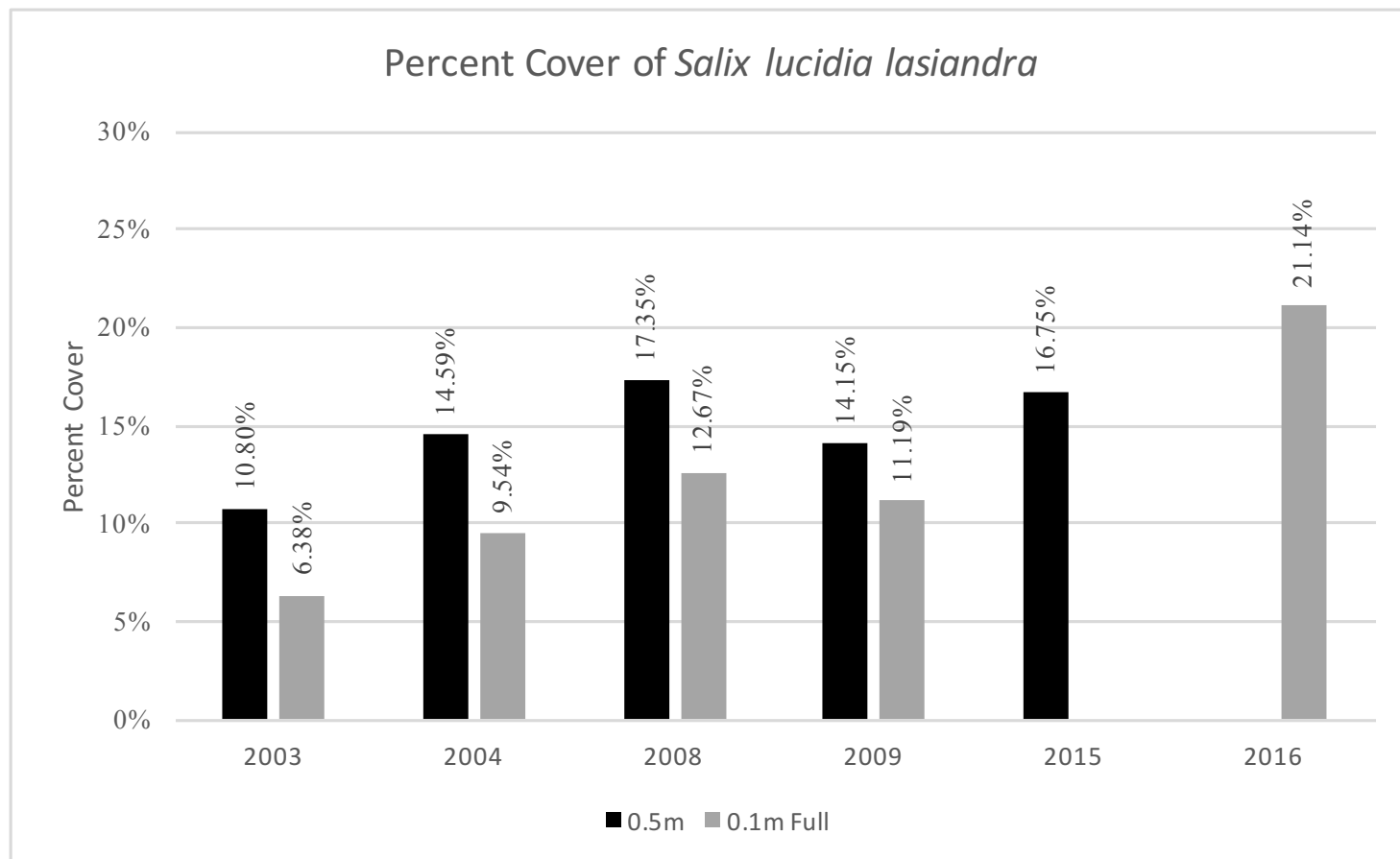

(c)

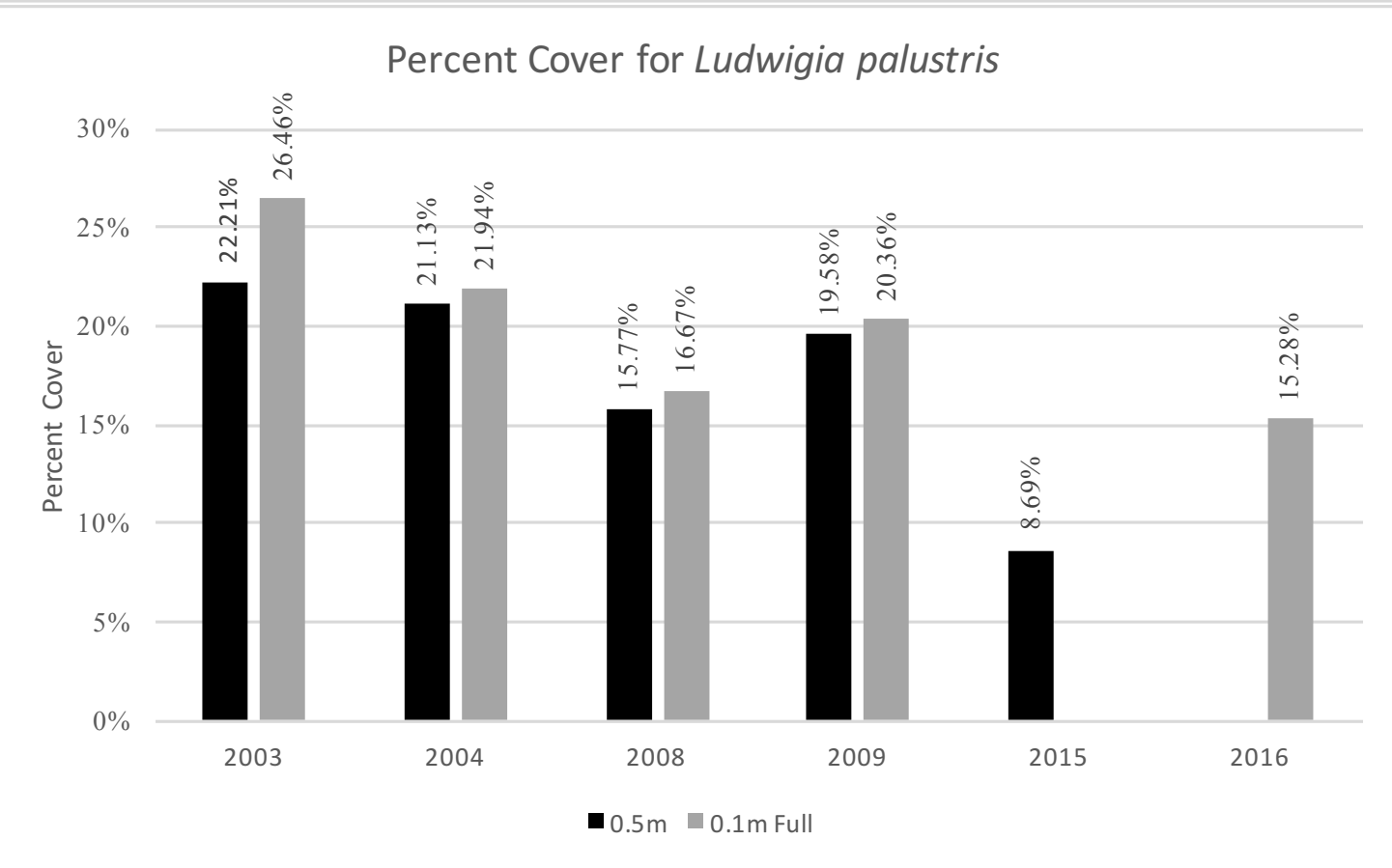

(d)

Figure 7 continued: Major Percent Cover Changes.

Percent cover in each monitoring year for all species with $\geq 5 \%$ cover in at least one monitoring year. Y-axis values are adjusted to allow for comparison between species with similar total percent cover. Panels show (a) Phalaris arundinacea (b) Persicaria sp. (c) Salix Iucidia lasiandra (d) Ludwigia palustris (e) Bidens cernua (f) Eragrostis hypnoides (g) Eleocharis palustris (h) Cyperus sp. and (i) Veronica sp. 


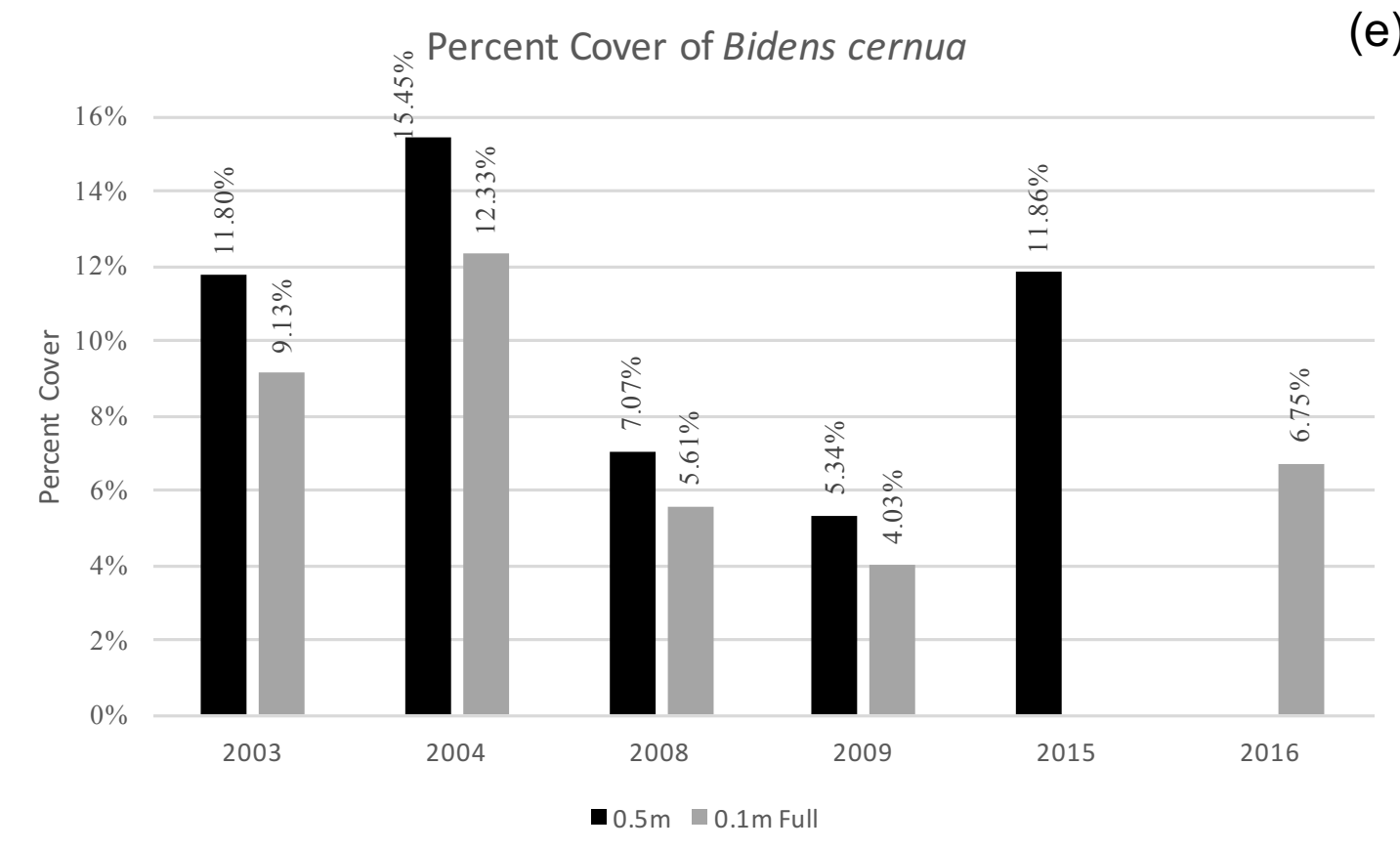

Percent Cover of Eragrostis hypnoides

(f)

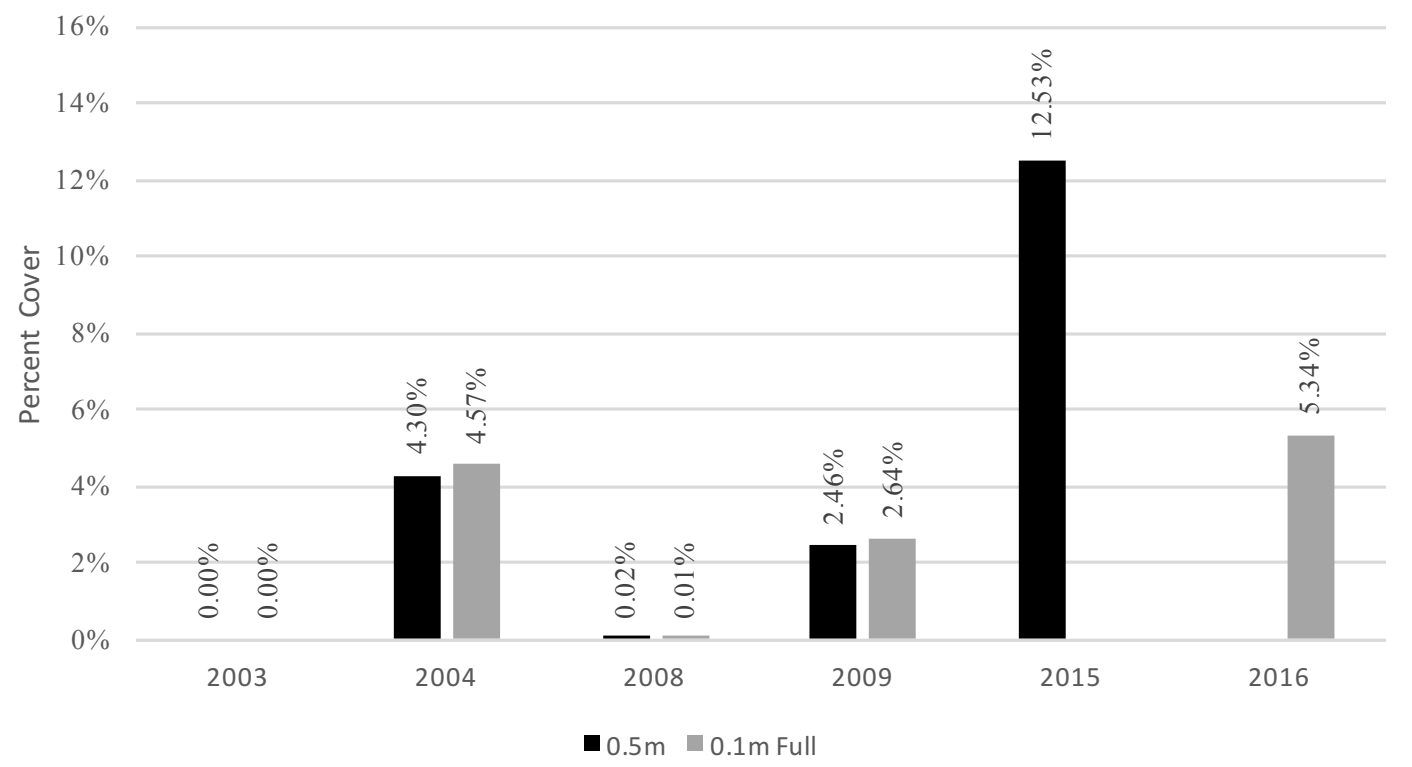

Figure 7 continued: Major Percent Cover Changes.

Percent cover in each monitoring year for all species with $\geq 5 \%$ cover in at least one monitoring year. Y-axis values are adjusted to allow for comparison between species with similar total percent cover. Panels show (a) Phalaris arundinacea (b) Persicaria sp. (c) Salix lucidia lasiandra (d) Ludwigia palustris (e) Bidens cernua (f) Eragrostis hypnoides (g) Eleocharis palustris (h) Cyperus sp. and (i) Veronica sp. 


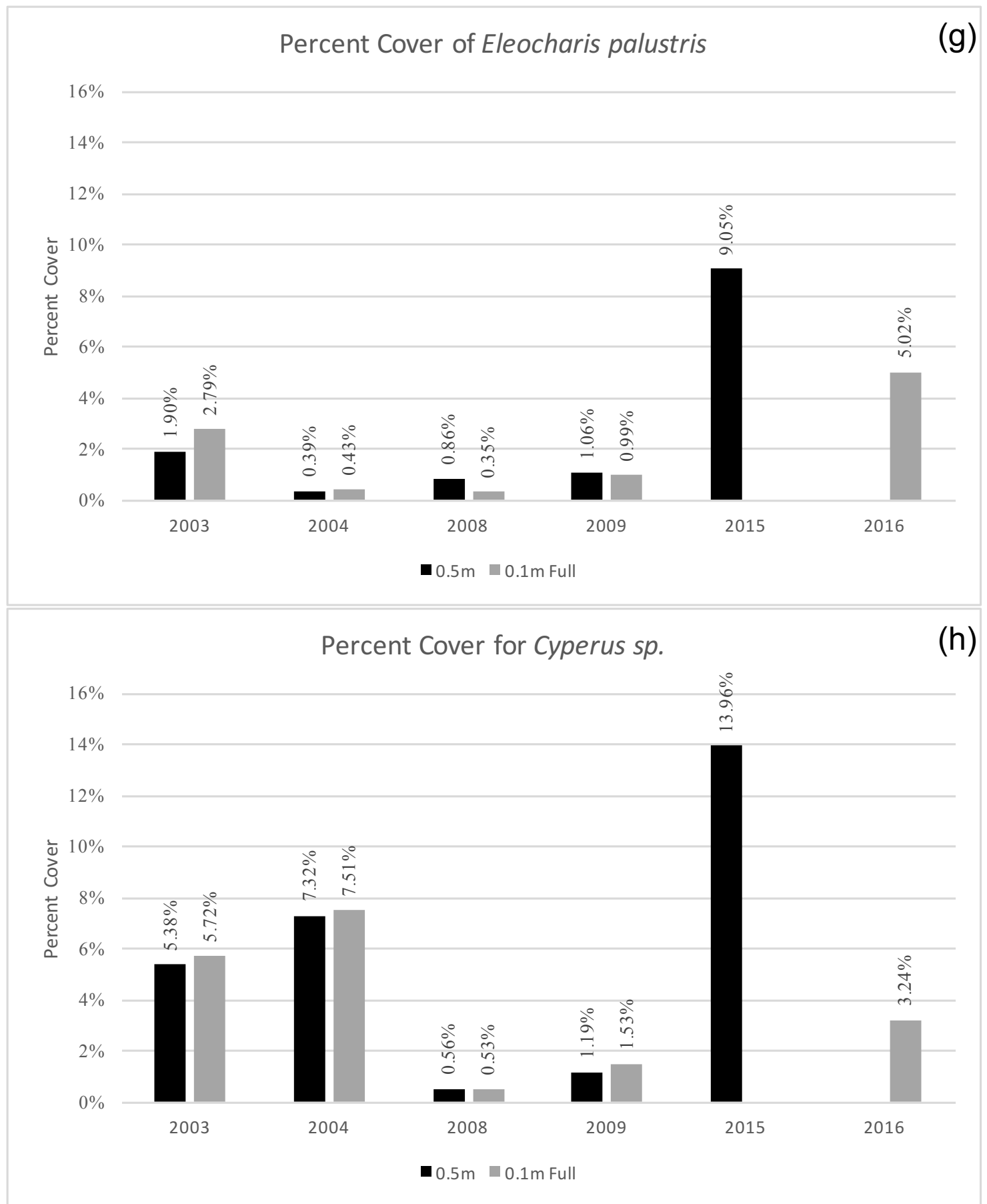

Figure 7 continued: Major Percent Cover Changes.

Percent cover in each monitoring year for all species with $\geq 5 \%$ cover in at least one monitoring year. Y-axis values are adjusted to allow for comparison between species with similar total percent cover. Panels show (a) Phalaris arundinacea (b) Persicaria sp. (c) Salix Iucidia lasiandra (d) Ludwigia palustris (e) Bidens cernua (f) Eragrostis hypnoides (g) Eleocharis palustris (h) Cyperus sp. and (i) Veronica sp. 


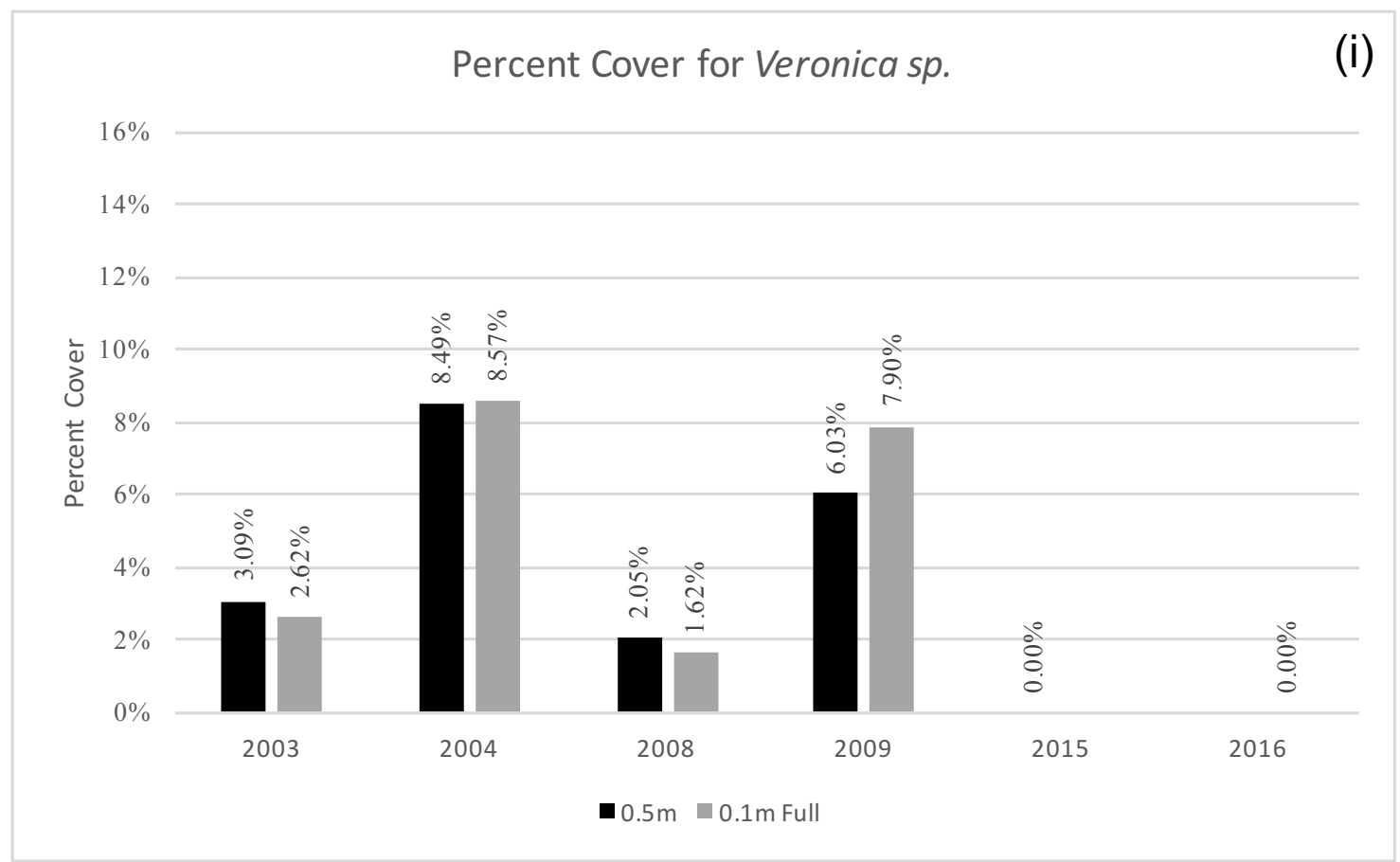

Figure 7 continued: Major Percent Cover Changes.

Percent cover in each monitoring year for all species with $\geq 5 \%$ cover in at least one monitoring year. Y-axis values are adjusted to allow for comparison between species with similar total percent cover. Panels show (a) Phalaris arundinacea (b) Persicaria sp. (c) Salix Iucidia lasiandra (d) Ludwigia palustris (e) Bidens cernua (f) Eragrostis hypnoides (g) Eleocharis palustris (h) Cyperus sp. and (i) Veronica sp.

\section{Change by Elevation and Inundation}

Many of the species with $\geq 5 \%$ cover in at least one monitoring year declined in overall cover between 2003 and 2009 , particularly in the lower elevation range $(5.8 \mathrm{ft}-9.8 \mathrm{ft}$ or $1.77 \mathrm{~m}$ to 2.99m) (NGVD 1929). However, many of those same species substantially increased in cover within those same reaches between 2009 and 2016 (Figures 8 - 16). These patterns are seen primarily in native herbaceous, most often annual species with growing seasons that begin in May or June (Figures 12 -15). However even Salix, a native woody species with an earlier growing season, saw a shift towards lower elevations in 2016 compared to 2009 (Figure 11).

These patterns did not hold for the two most dominant species on site however. Phalaris saw an overall shift towards higher elevations between 2003 and 2009 . From 2009 to 2016 it 
declined in overall presence along all elevations within our study area (Figure 8). Conversely, Persicaria did not shift significantly in elevation and experienced a steady increase in cover regardless of water level changes within the study area over all years (Figure 9).

Maximum inundation and duration of flooding were found to have a very strong positive correlation (Spearmen's rho $=0.99, \mathrm{p}$-value $<0.01$ ) for every monitoring year so we used maximum inundation only in our analysis of water levels and species abundance. The relationship between maximum inundation annually and during only the first two months of most species growing seasons varied substantially between 2003 and 2016 . The highest recorded water elevation in 2003 within SBW was $10.78 \mathrm{ft}$ (3.29m), and aside from lower water elevations in March, the first two months of most species' growing seasons did not deviate substantially from the annual maximum inundation depth. This overall pattern of similar annual and early growing season water levels occurred in most active water management years (Appendix B). The average annual maximum inundation depth during active management years was $13.79 \mathrm{ft}$ (4.2m). The deepest inundations were experienced between 2010 and 2012, with 2011 experiencing the highest inundation depths of any year (annual $=19.06 \mathrm{ft}, 5.81 \mathrm{~m}$ ).

There was a greater contrast between annual and early growing season maximum inundation depths during the inactive management years of 2015 and 2016 . The year 2015 experienced a slightly below average annual inundation depth $(12.38 \mathrm{ft}, 3.77 \mathrm{~m})$, and all early growing season maximum depths were the lowest they've been since 2003 (8.52ft to $7.33 \mathrm{ft}$, $2.6 \mathrm{~m}$ to $2.23 \mathrm{~m})$. The year 2016 experienced average annual and early growing season maximum depths until May - July, when depths dropped below average (Appendix B). Maximum inundation depths by June-July of 2016 were lower than any active management year, and only slightly above 2015 depths during that same time period. 
Phalaris arundinacea (0.1m Full)

2003

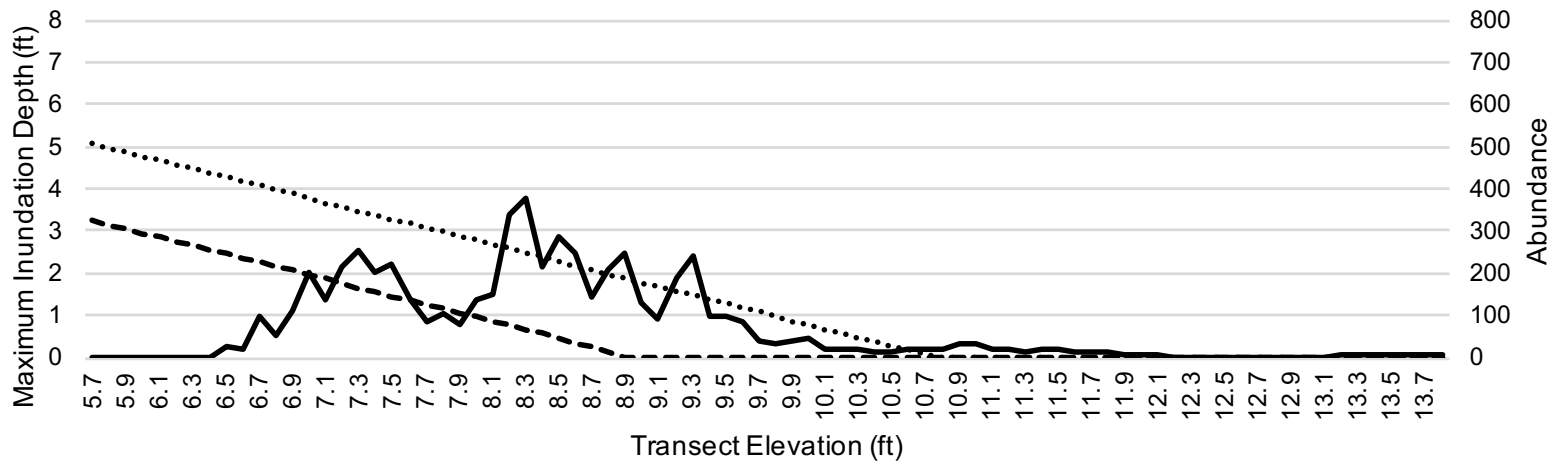

2009

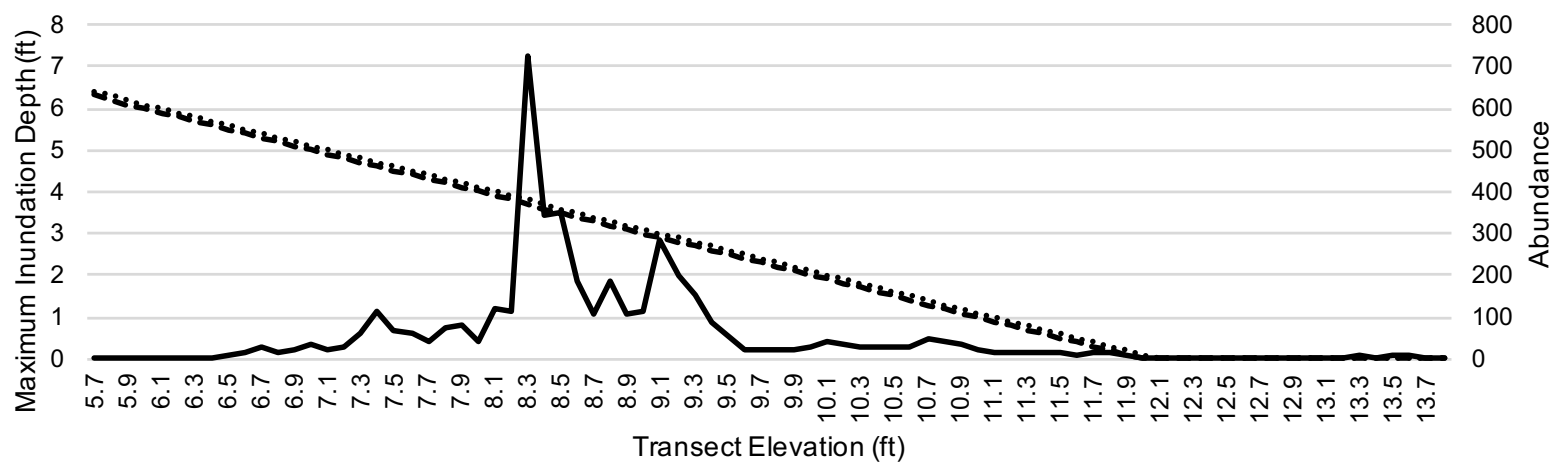

2016

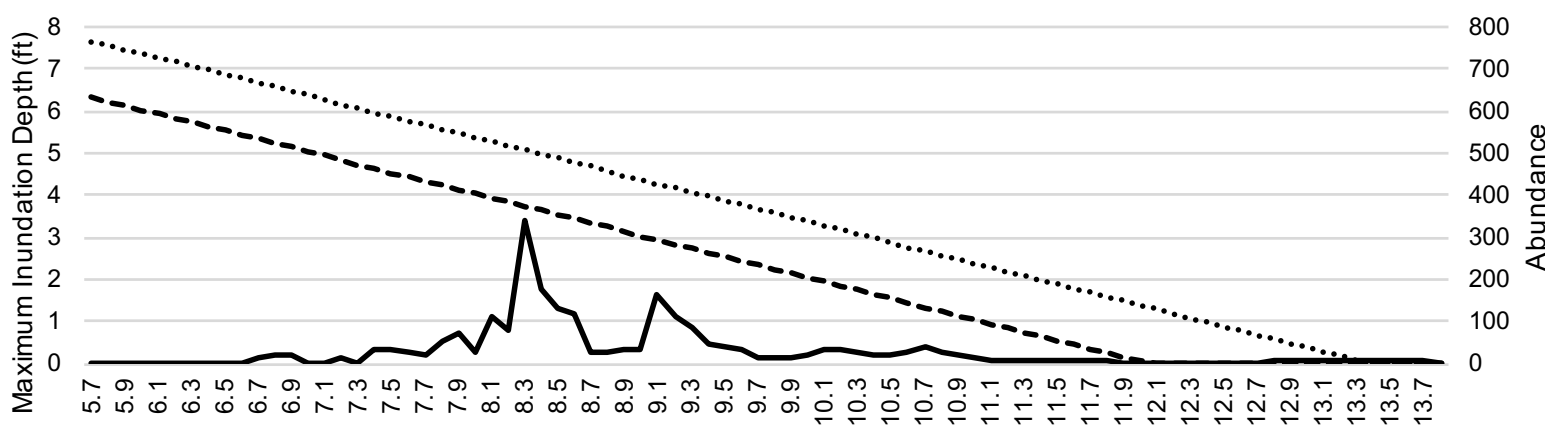

Transect Elevation (ft)

- - Max Innundation (ft) First 2 Mo. (March - April)

Max Innundation (ft) Water Yr

Species Presence

Figure 8: Cover Change by Elevation and Maximum Inundation for Phalaris arundinacea. Overall cover of Phalaris arundinacea along the elevation gradient within our study area and the maximum water depth experienced both annually and during only the first two months of this species' growing season (March - April). 2003 indicates species presence and water depths prior to active water management, 2009 is 6 years into active water management, and 2016 is after 11 years of active management and the second year of inactive management of the water control structure. 


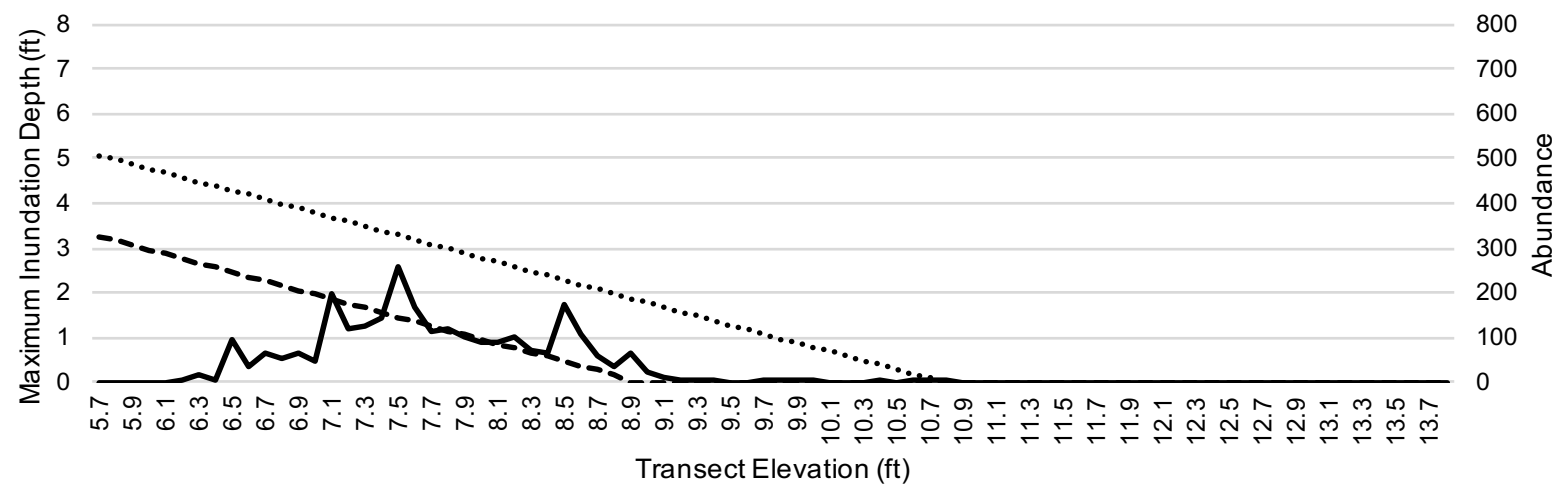

2009

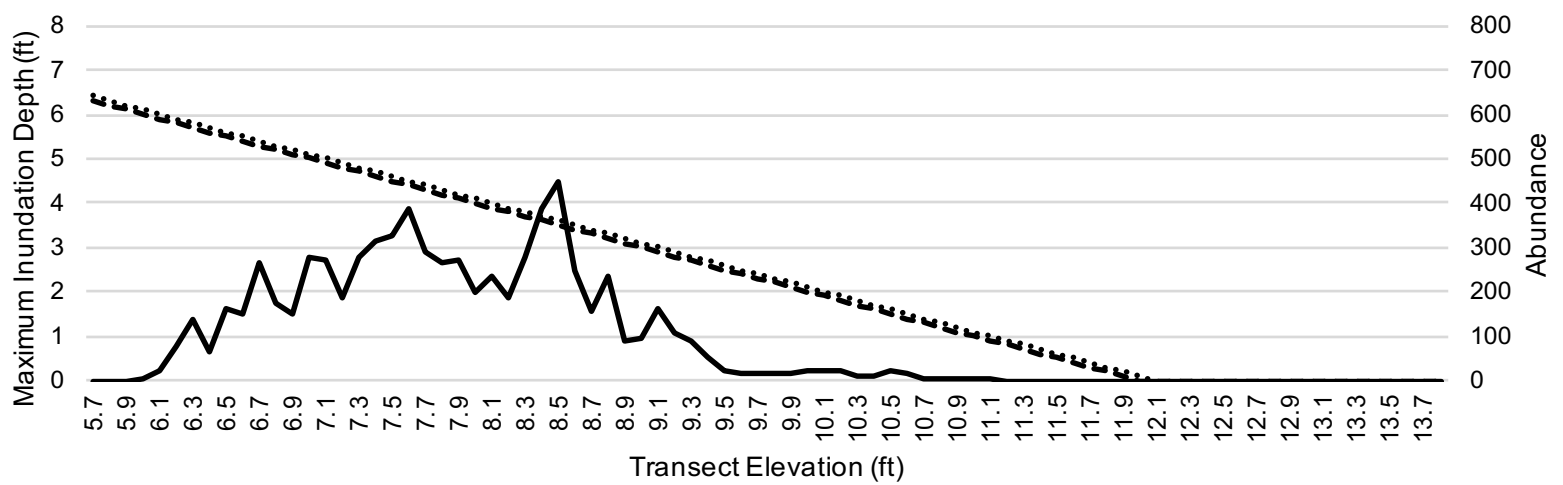

2016

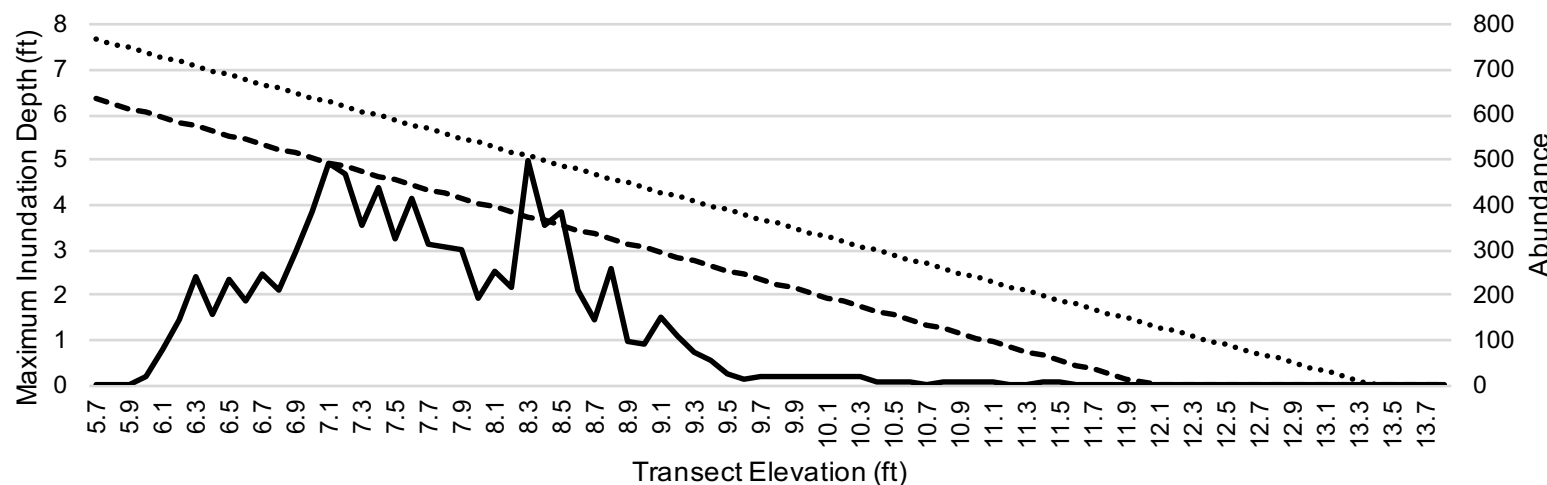

- - Max Innundation (ft) First 2 Mo. (March - April) …... Max Innundation (ft) Water Yr — Species Presence

Figure 9: Cover Change by Elevation and Maximum Inundation for Persicaria sp.

Overall cover of Persicaria (smartweed) along the elevation gradient within our study area and the maximum water depth experienced both annually and during only the first two months of this species' growing season (March - April). 2003 indicates species presence and water levels prior to active water management, 2009 is 6 years into active water management, and 2016 is after 11 years of active management and the second year of inactive management of the water control structure. 


\section{Ludwigia palustris (0.1m Full)}

2003

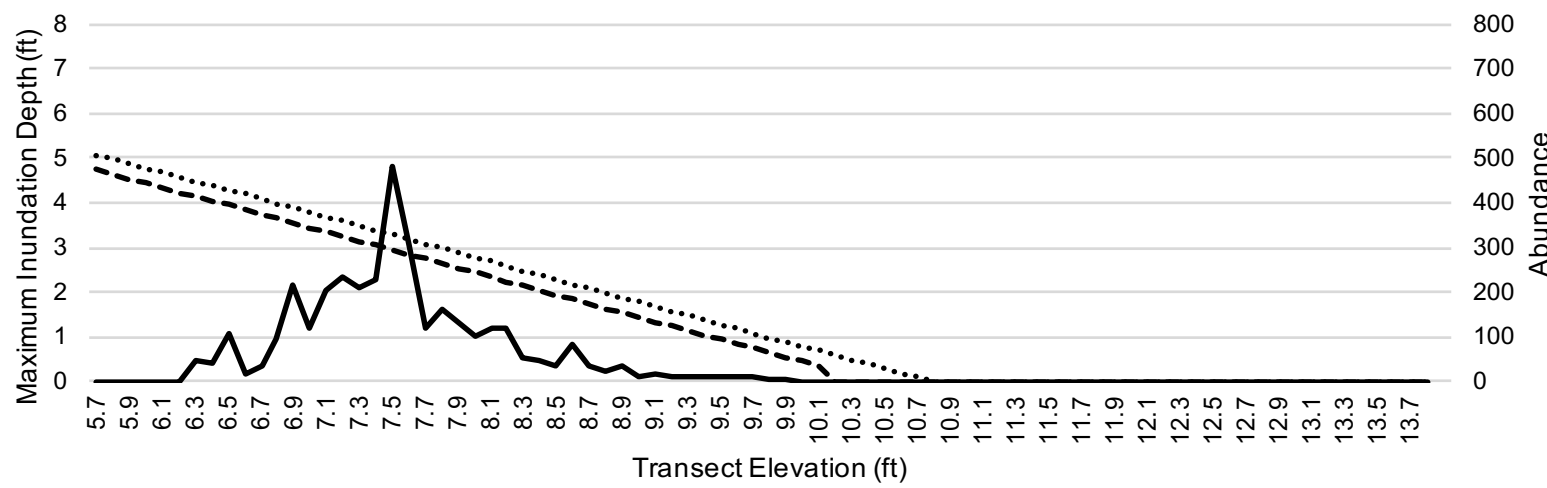

2009

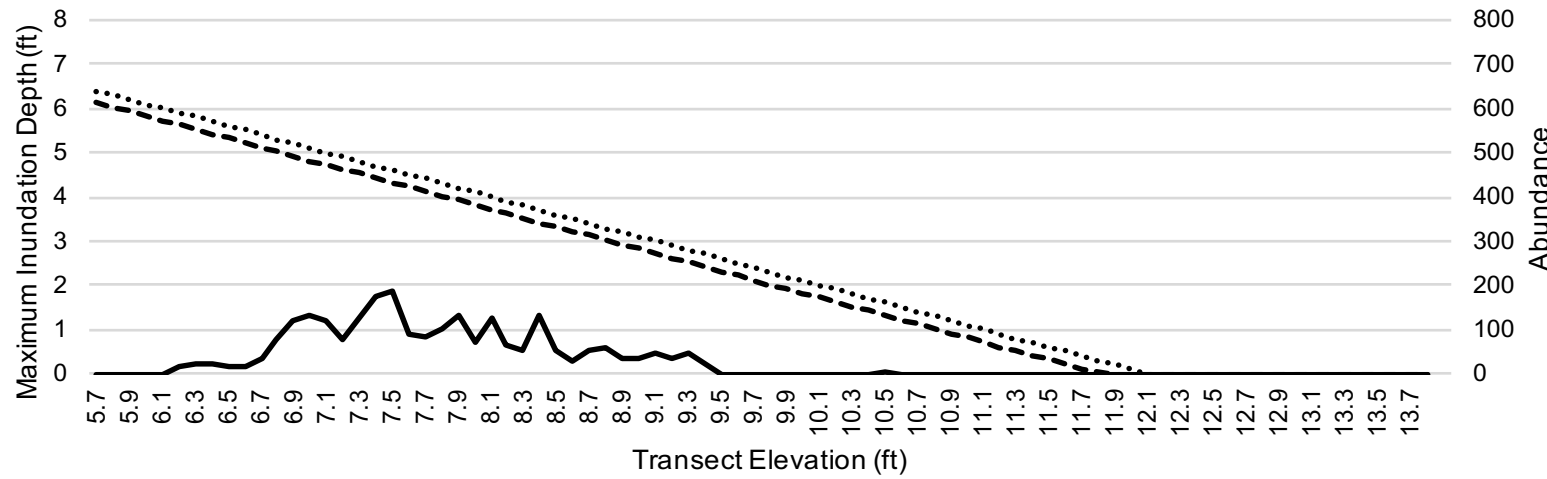

2016

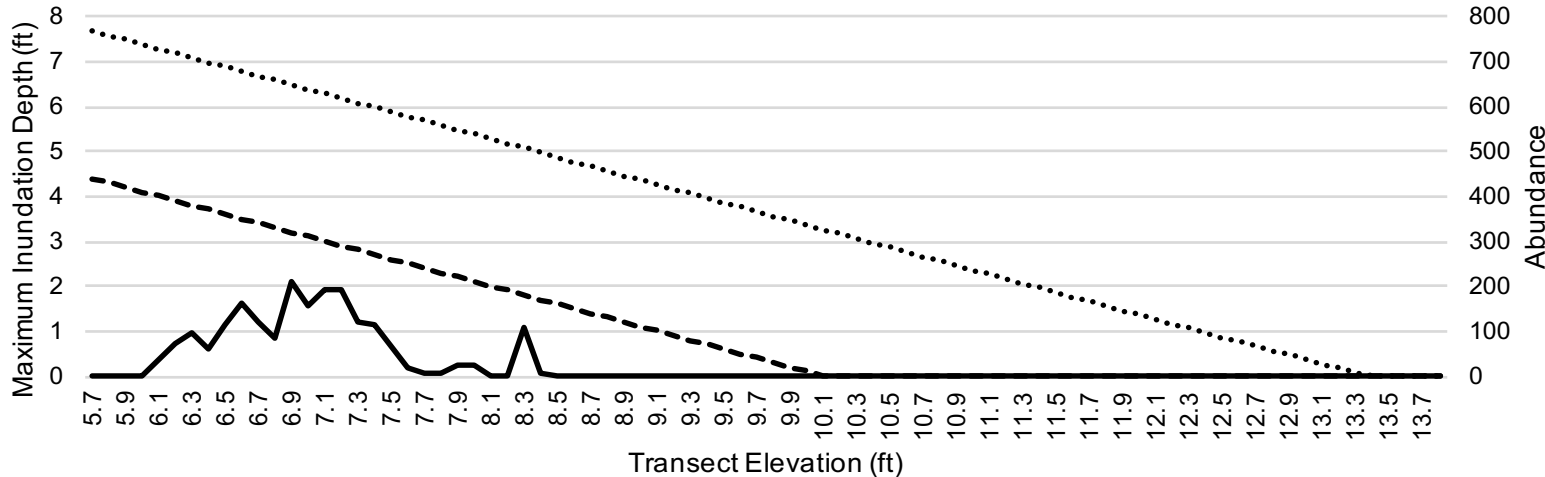

- - Max Innundation (ft) First 2 Mo. (May - June) $\quad$....... Max Innundation (ft) Water Yr —Species Presence

Figure 10: Cover Change by Elevation and Maximum Inundation for Ludwigia palustris. Overall cover of Ludwigia palustris along the elevation gradient within our study area and the maximum water depth experienced both annually and during only the first two months of this species' growing season (May - June). 2003 indicates species presence and water levels prior to active water management, 2009 is 6 years into active water management, and 2016 is after 11 years of active management and the second year of inactive management of the water control structure. 
Salix lucidia lasiandra (0.1m Full)

2003

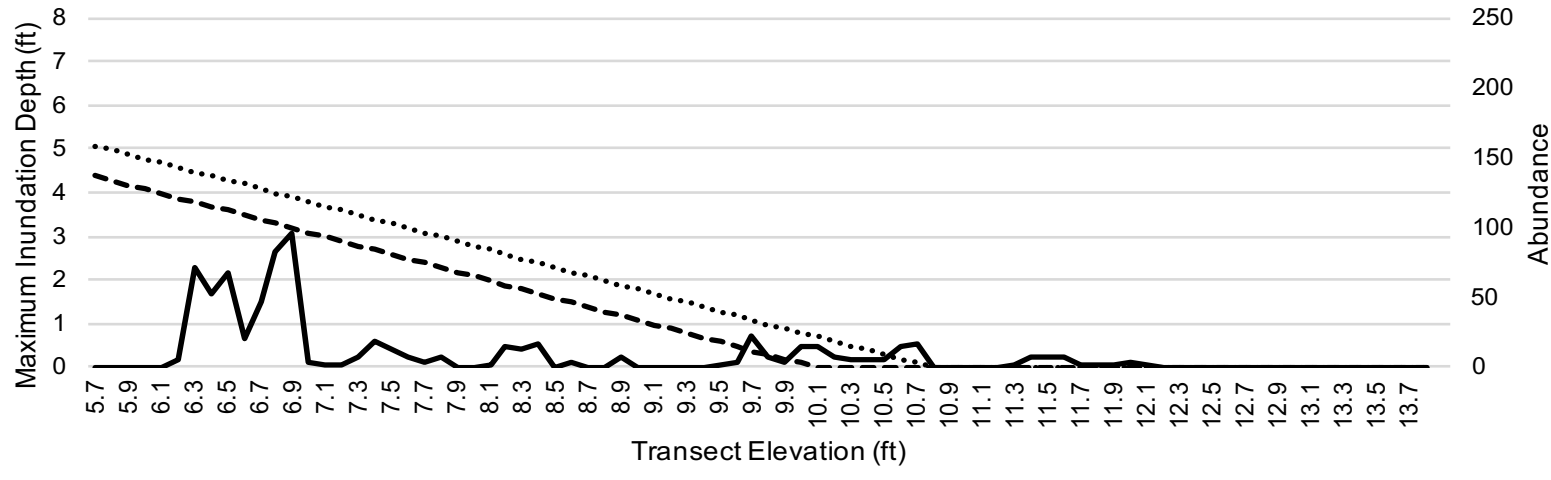

2009

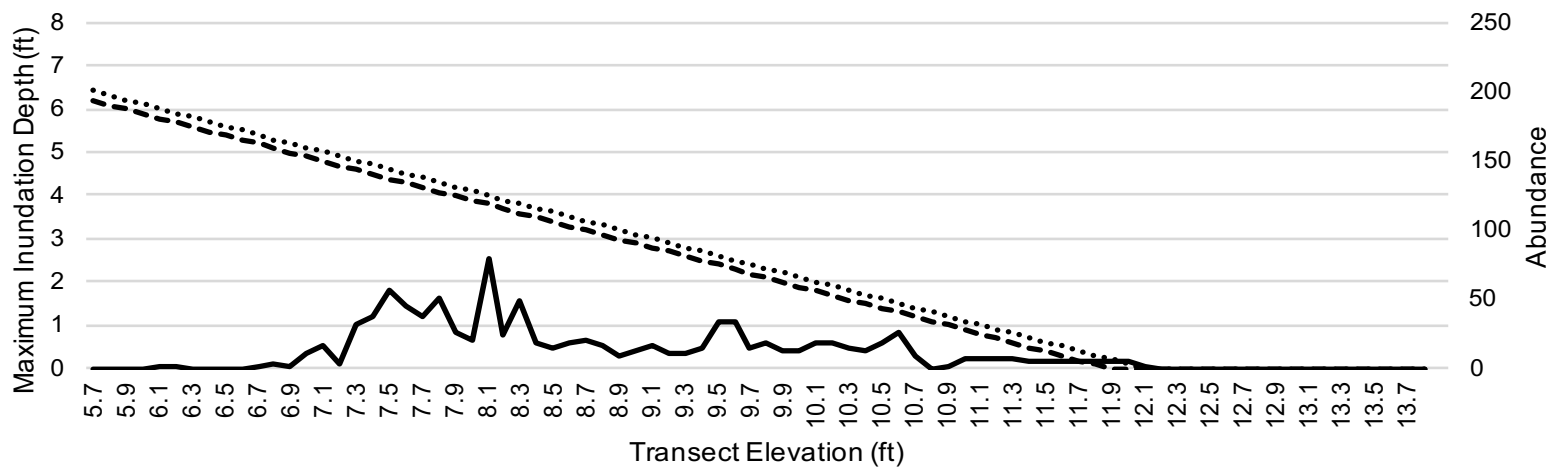

2016

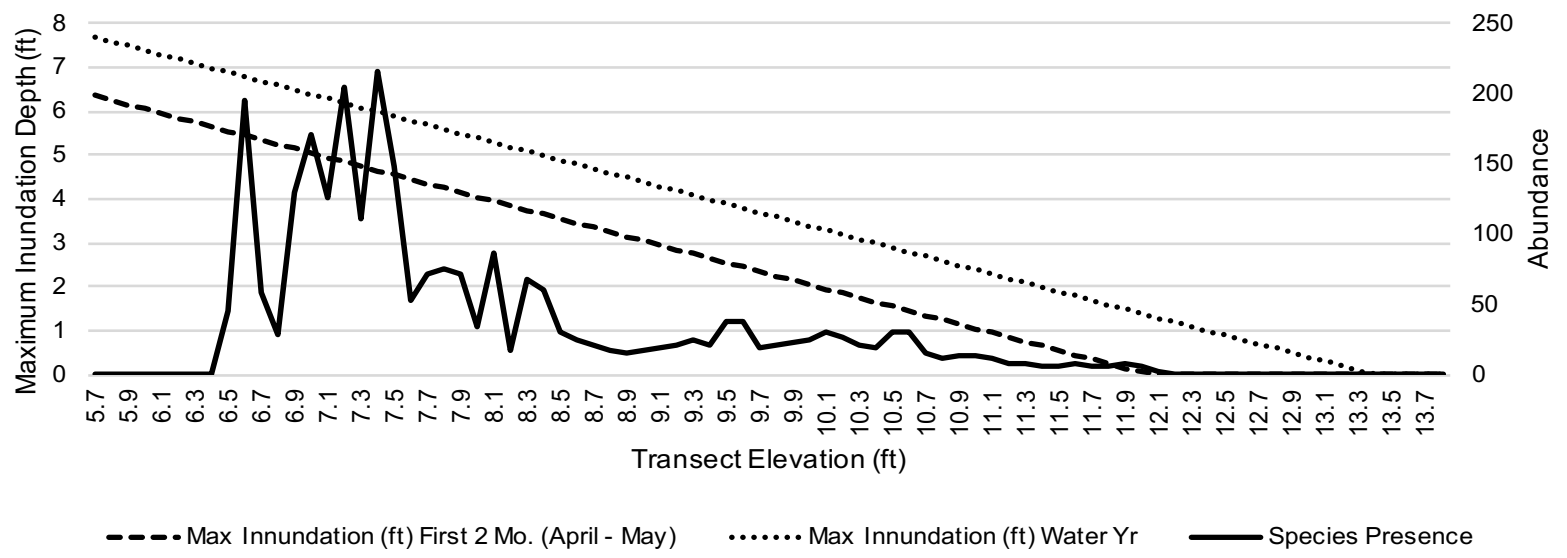

Figure 11: Cover Change by Elevation and Maximum Inundation for Salix lucidia lasiandra. Overall cover of Salix lucidia lasiandra along the elevation gradient within our study area and the maximum water depth experienced both annually and during only the first two months of this species' growing season (April - May). 2003 indicates species presence and water levels prior to active water management, 2009 is 6 years into active water management, and 2016 is after 11 years of active management and the second year of inactive management of the water control structure. 

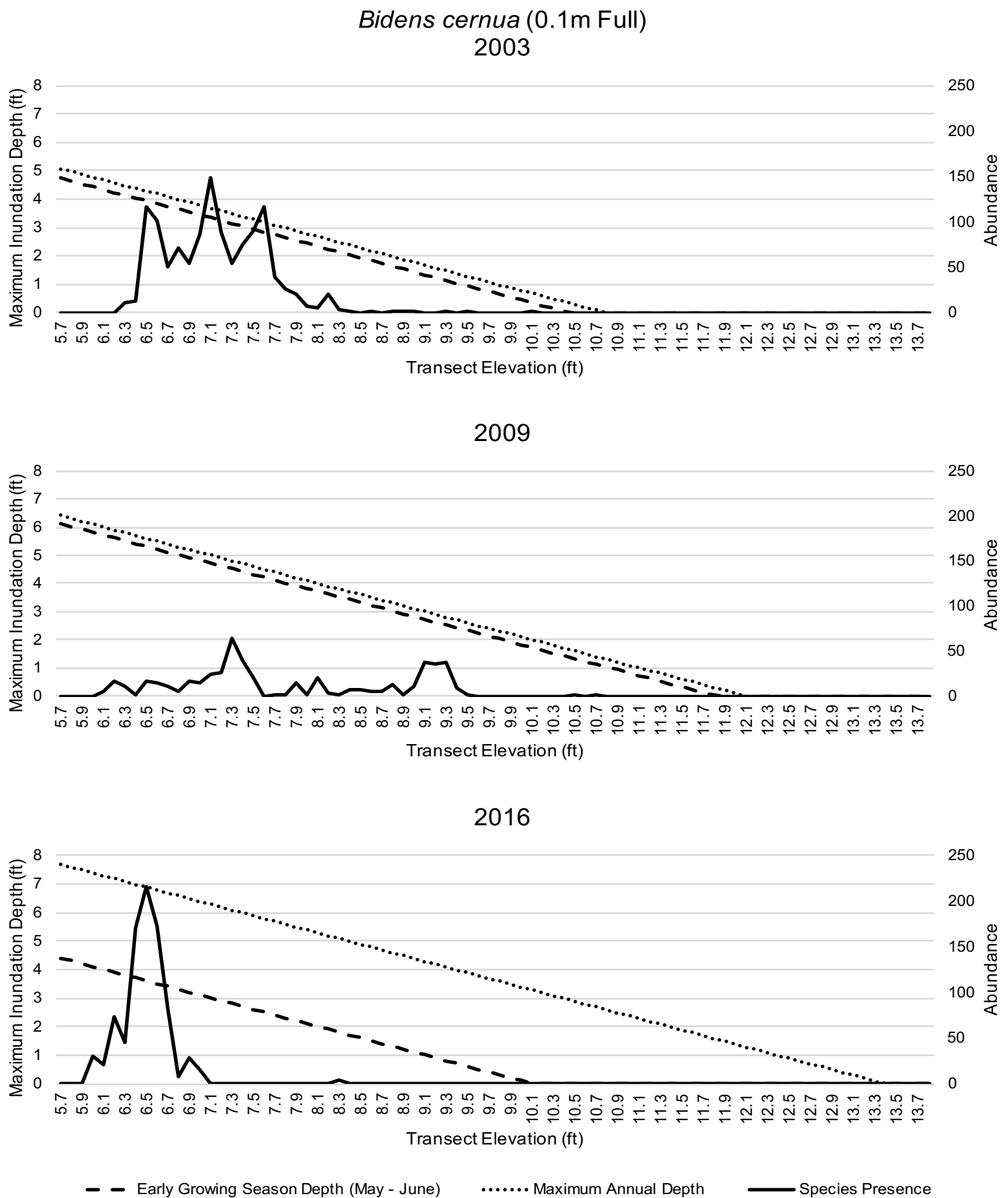

Figure 12: Cover Change by Elevation and Maximum Inundation for Bidens cernua. Overall cover of Bidens cernua along the elevation gradient within our study area and the maximum water depth experienced both annually and during only the first two months of this species' growing season (May - June). 2003 indicates species presence and water levels prior to active water management, 2009 is 6 years into active water management, and 2016 is after 11 years of active management and the second year of inactive management of the water control structure. 


\section{Eragrostis hypnoides (0.1m Full)}

2003

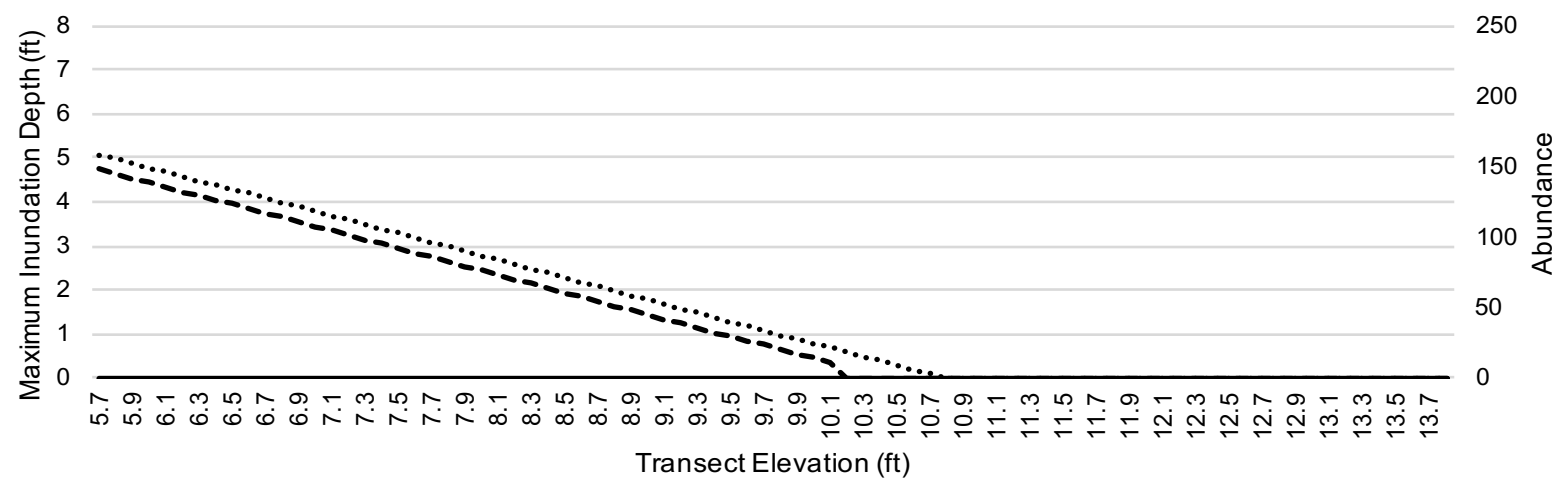

2009

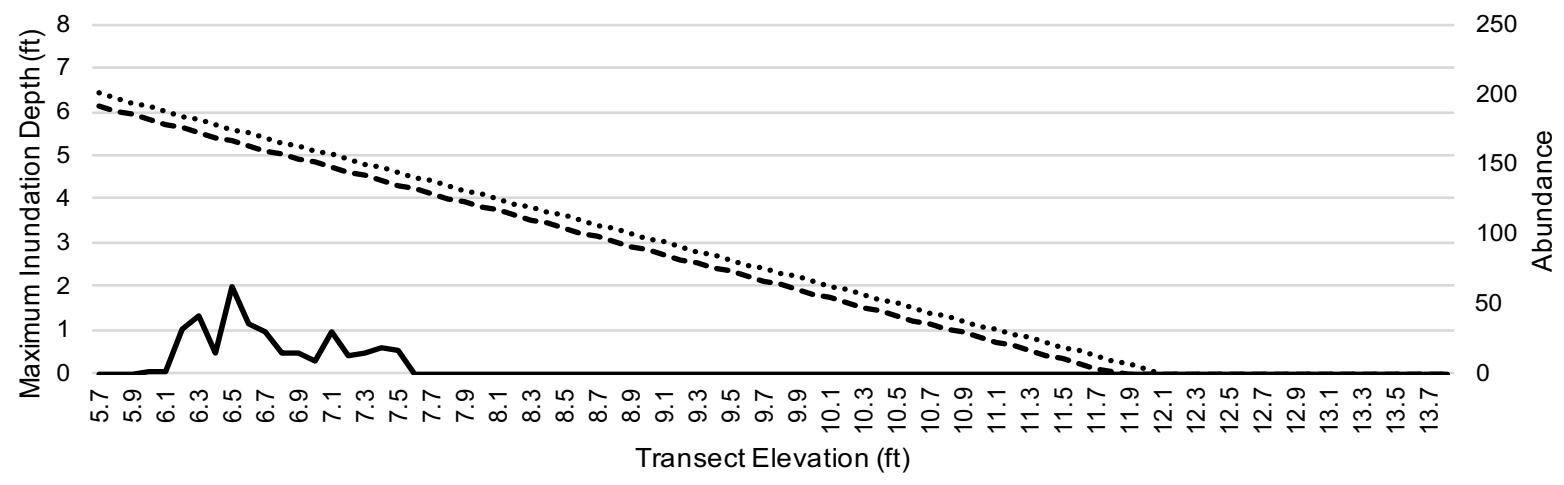

2016

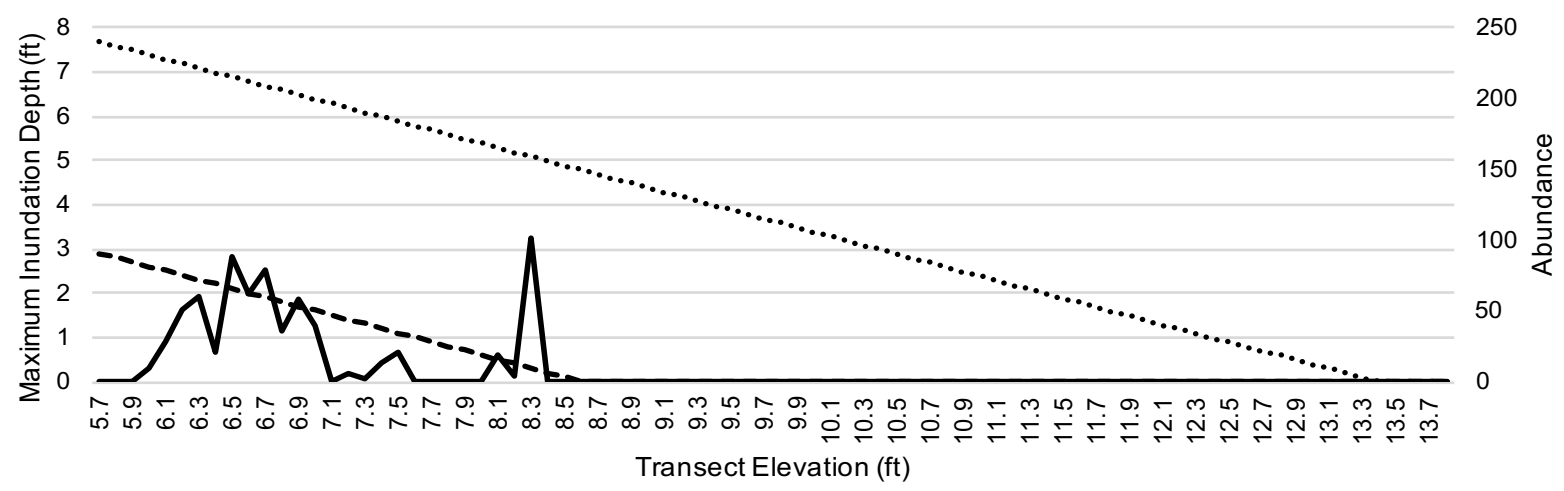

- - Max Innundation (ft) First 2 Mo. (June - July) ...... Max Innundation (ft) Water Yr $\quad$ Species Presence

Figure 13: Cover Change by Elevation and Maximum Inundation for Eragrostis hypnoides. Overall cover of Eragrostis hypnoides along the elevation gradient within our study area and the maximum water depth experienced both annually and during only the first two months of this species' growing season (June - July). 2003 indicates species presence and water levels prior to active water management, 2009 is 6 years into active water management, and 2016 is after 11 years of active management and the second year of inactive management of the water control structure. 


\section{Eleocharis palustris (0.1m Full)}

2003

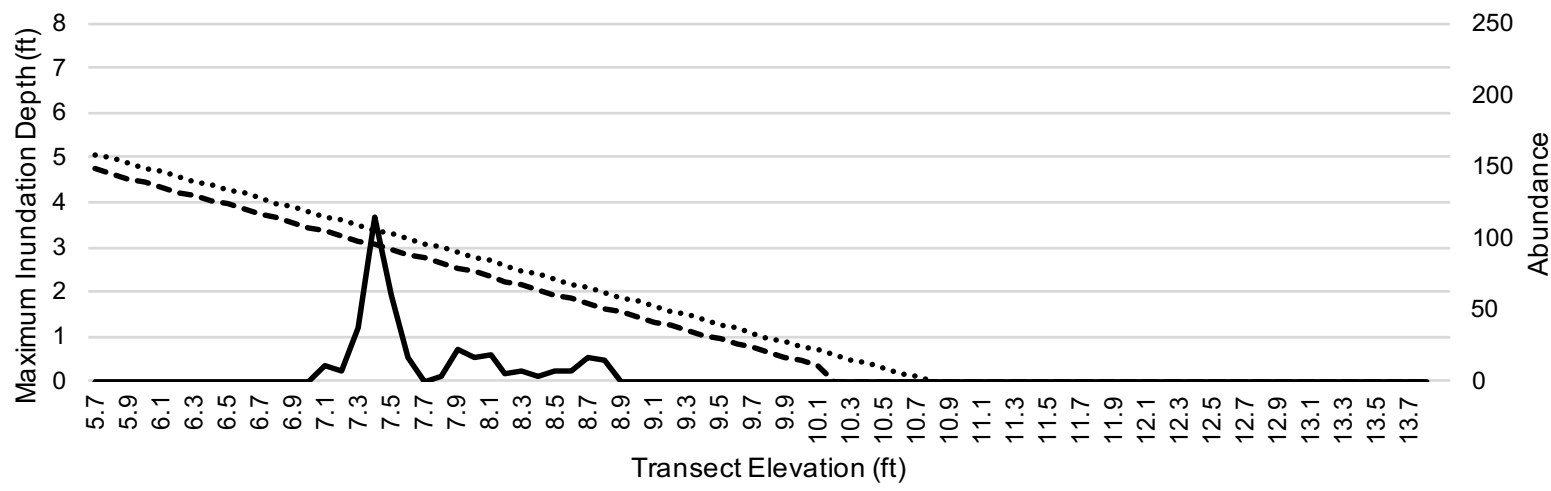

2009

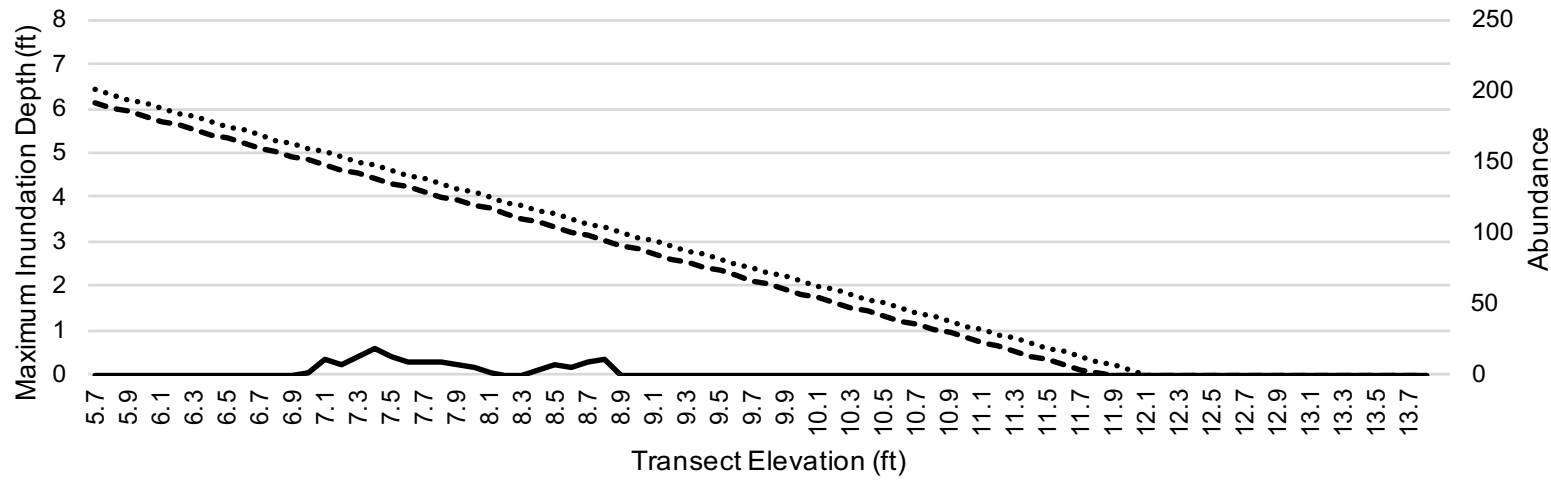

2016

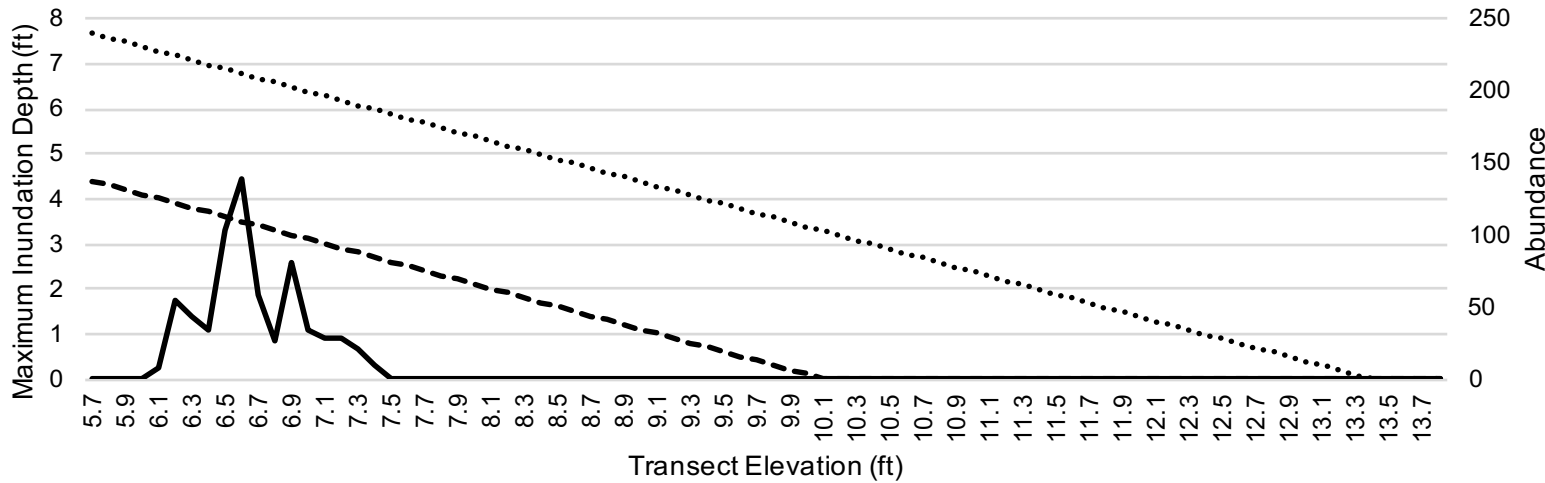

- --Max Innundation (ft) First 2 Mo. (May - June) $\quad \cdots . .$. Max Innundation (ft) Water Yr —Species Presence

Figure 14: Cover Change by Elevation and Maximum Inundation for Eleocharis palustris. Overall cover of Eleocharis palustris along the elevation gradient within our study area and the maximum water depth experienced both annually and during only the first two months of this species' growing season (May - June). 2003 indicates species presence and water levels prior to active water management, 2009 is 6 years into active water management, and 2016 is after 11 years of active management and the second year of inactive management of the water control structure. 


\section{Cyperus sp. (0.1m Full)}

2003
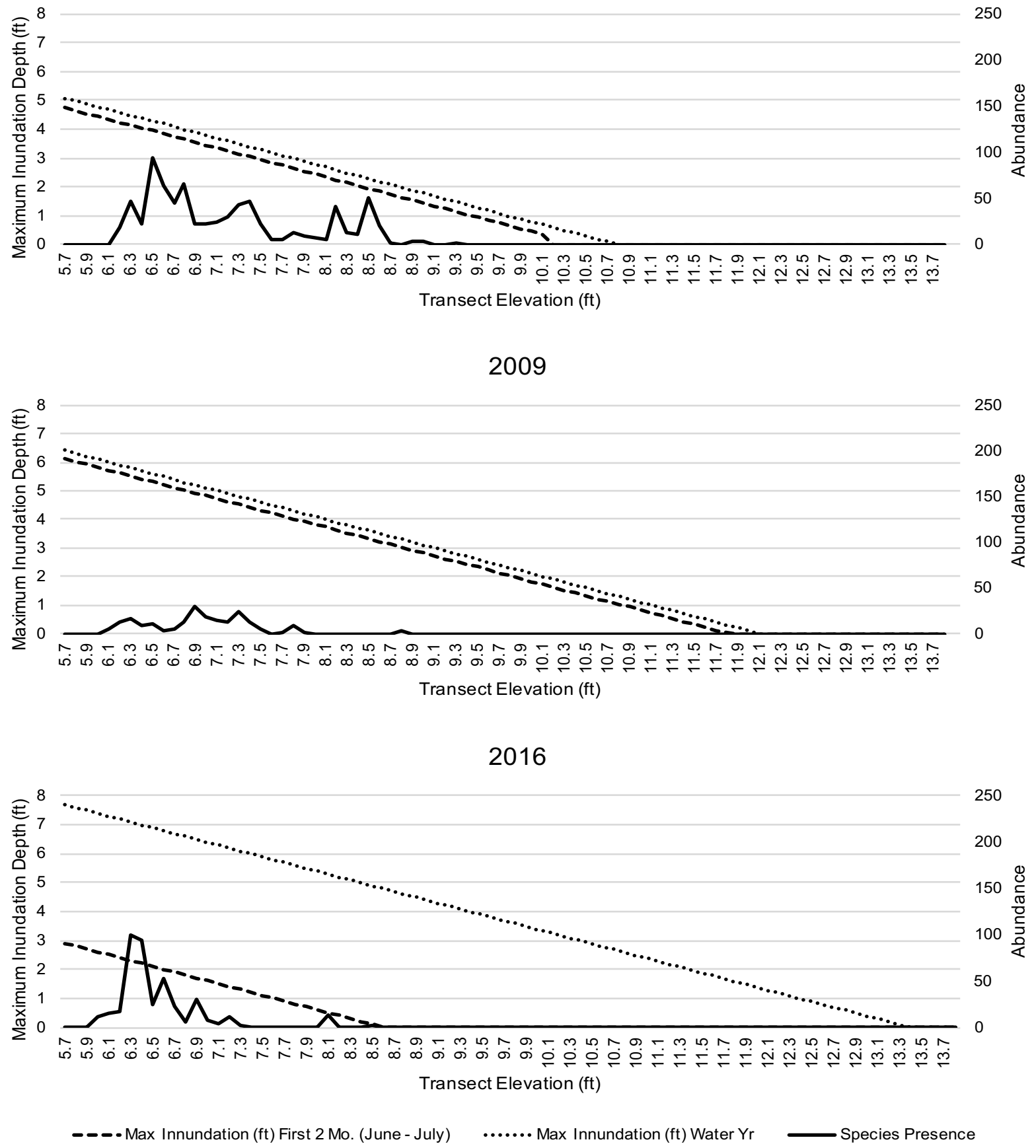

Figure 15: Cover Change by Elevation and Maximum Inundation for Cyperus sp.

Overall cover of Cyperus along the elevation gradient within our study area and the maximum water depth experienced both annually and during only the first two months of this species' growing season (June - July). 2003 indicates species presence and water levels prior to active water management, 2009 is 6 years into active water management, and 2016 is after 11 years of active management and the second year of inactive management of the water control structure. 

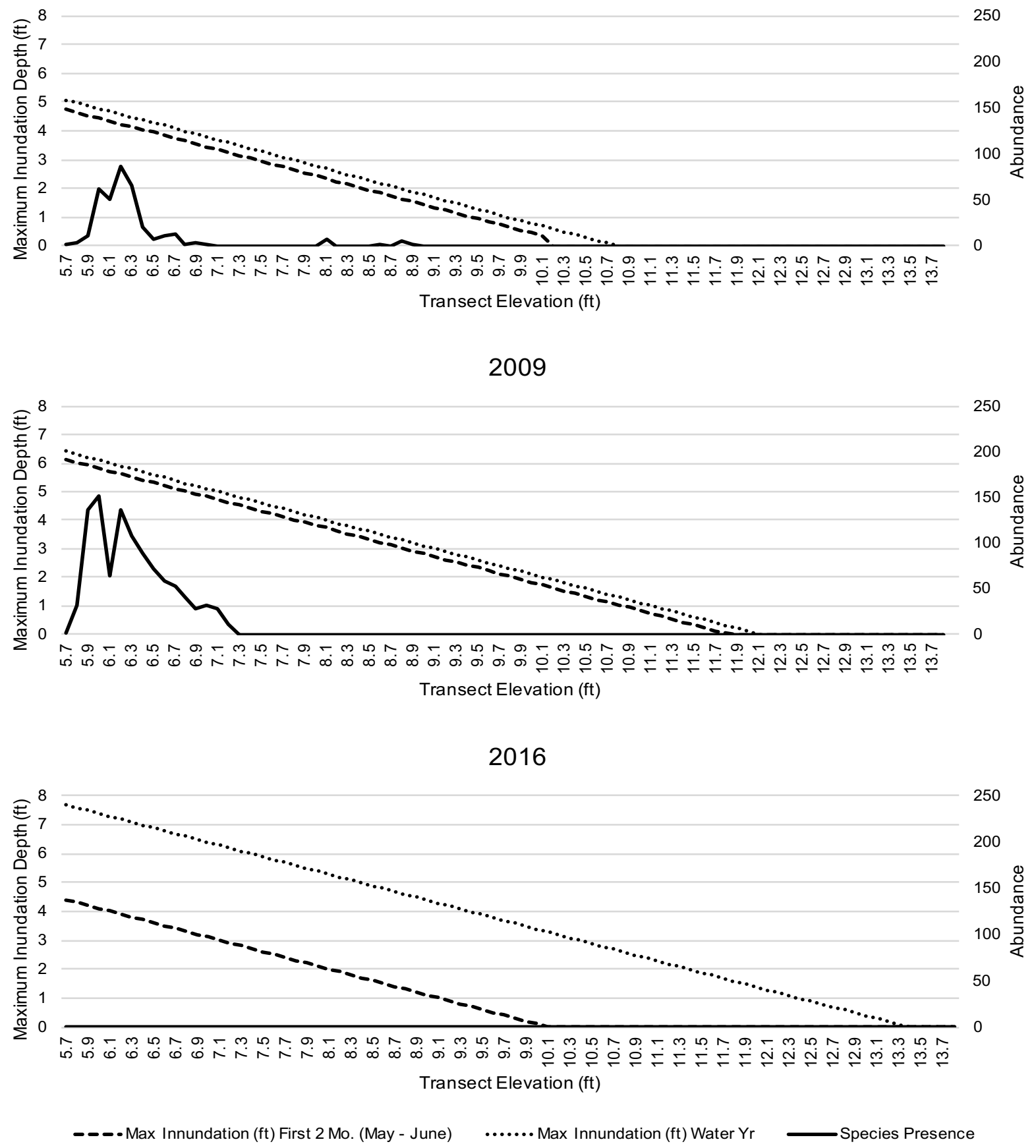

Figure 16: Cover Change by Elevation and Maximum Inundation for Veronica sp.

Overall cover of Veronica along the elevation gradient within our study area and the maximum water depth experienced both annually and during only the first two months of this species' growing season (May - June). 2003 indicates species presence and water levels prior to active water management, 2009 is 6 years into active water management, and 2016 is after 11 years of active management and the second year of inactive management of the water control structure. 


\section{Change by Wetland Indicator Type and Elevation}

Obligate species experienced an overall reduction in cover across almost all elevation ranges between 2003 and 2009. This pattern continued in 2016 for elevations above $7.1 \mathrm{ft}$ $(2.16 \mathrm{~m})$. However, obligate species experienced a substantial increase in cover in elevations below $7.1 \mathrm{ft}(2.16 \mathrm{~m})$ in 2016 (Figure 17).

Facultative species experienced a considerable increase in low elevations between 2003 and 2009, and a decrease in higher elevations during the same time period. This pattern shifted between 2009 and 2016, with facultative species declining in cover in low elevations and experiencing the most dramatic increase in the medium to high elevation range $(7.4 \mathrm{ft}-9 \mathrm{ft})$

(Figure 17). This range in which facultative species experienced the greatest increases between 2009 and 2016 is just above the elevation range in which obligate species experienced increases during the same time period.

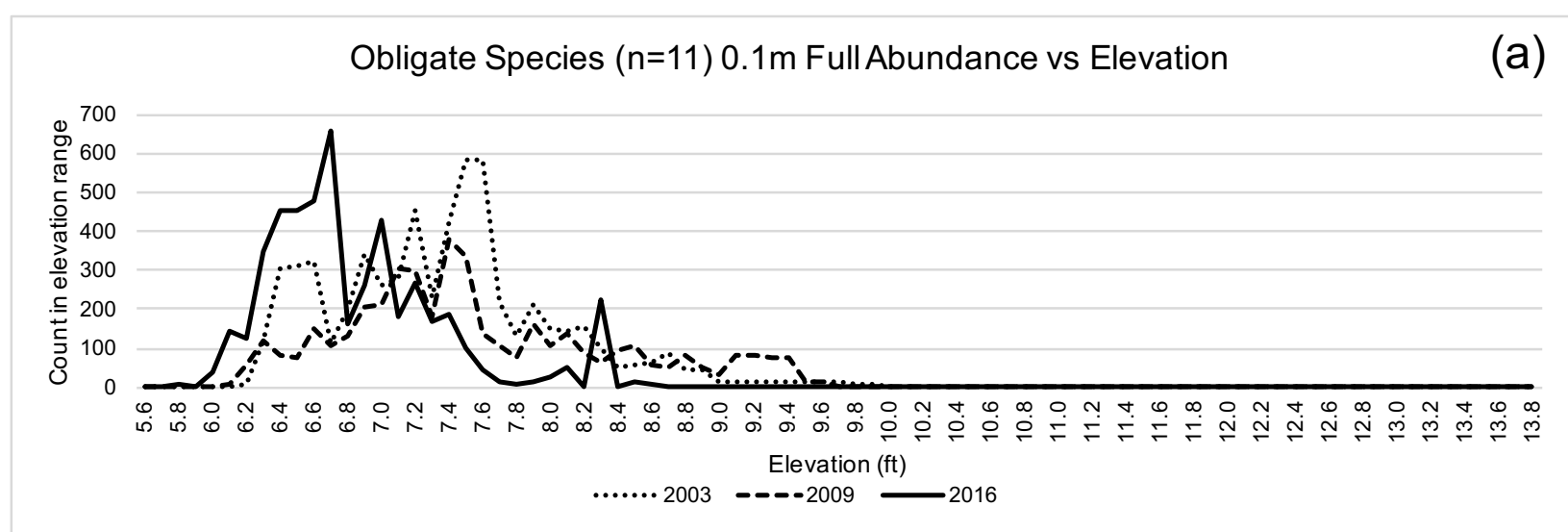

Figure 17: Wetland Indicator Type Changes Over Time by Elevation.

Species abundance per $0.1 \mathrm{ft}$ in elevation for (a) obligate and (b) facultative wetland species. Only annual herbaceous species were used to most effectively isolate the effect of shifting water levels along the elevation gradient between study years. Note the difference in y-axis ranges if comparing between graphs due to less overall presence of facultative species compared to obligates. 
Facultative (FACW to FACU) Species $(n=15) 0.1 \mathrm{~m}$ Full Abundance vs Elevation

(b)

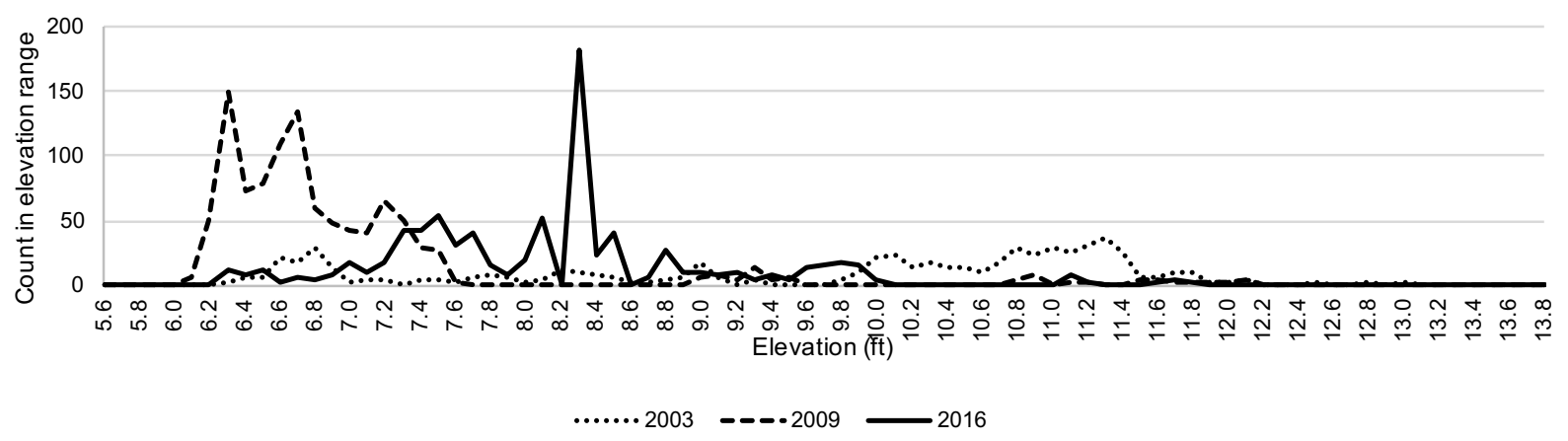

Figure 17 continued: Wetland Indicator Type Changes Over Time by Elevation.

Species abundance per $0.1 \mathrm{ft}$ in elevation for (a) obligate and (b) facultative wetland species. Only annual herbaceous species were used to most effectively isolate the effect of shifting water levels along the elevation gradient between study years. Note the difference in y-axis ranges if comparing between graphs due to less overall presence of facultative species compared to obligates.

\section{Dominant Species Interactions}

We found that Phalaris was replaced in significant amounts by all species with $\geq 5 \%$ cover between 2003 and 2015/2016 (Table 7). Conversely, Persicaria had significantly replaced all species with $\geq 5 \%$ cover except Salix lucida lasiandra (Pacific willow) between 2003 and $2015 / 2016$. The greatest overall number of replacements that occurred across all three datasets were between Phalaris and Persicaria. Outside of these co-dominant species, Phalaris was replaced most often by Salix and Persicaria most often replaced Ludwigia palustris. The Veronica sp. was eliminated and therefore did not replace any species, and was primarily replaced by Persicaria. 
Table 7: McNemar's Test of Co-Dominant Species Replacement. McNemar's test of the two co-dominant species (Phalaris arundinacea (reed canarygrass) and Persicaria (smartweed)) against other species with $\geq 5 \%$ cover in at least one study year. "Replaced RCG/SW" is a count of every point along a transect that was occupied by reed canarygrass (RCG) or smartweed (SW) in 2003 that was occupied by the other species in 2015 or 2016. "Replaced by RCG/SW" is a count of every point along a transect that was occupied by the species in 2003 and then occupied by RCG or SW in 2015 or 2016.

\begin{tabular}{|c|c|c|c|c|c|c|c|c|c|}
\hline \multicolumn{5}{|c|}{ Phalaris arundinacea $: 0.5 \mathrm{~m}$} & \multicolumn{5}{|c|}{ Persicaria amphibia : $0.5 \mathrm{~m}$} \\
\hline \multicolumn{5}{|c|}{2003 vs 2015} & \multicolumn{5}{|c|}{2003 vs 2015} \\
\hline Species & $\begin{array}{c}\text { Replaced } \\
\text { RCG }\end{array}$ & $\begin{array}{c}\text { Replaced } \\
\text { By RCG }\end{array}$ & $\begin{array}{l}\text { Chi- } \\
\text { squared }\end{array}$ & $p$-value & Species & $\begin{array}{c}\text { Replaced } \\
\text { SW }\end{array}$ & $\begin{array}{c}\text { Replaced } \\
\text { By SW }\end{array}$ & Chi-squared & $p$-value \\
\hline Eragrostis hypnoides & 86 & 0 & 84.01 & $<0.001$ & Eragrostis hypnoides & 52 & 0 & 50.02 & $<0.001$ \\
\hline Persicaria $s p$ & 981 & 11 & 946.53 & $<0.001$ & Philaris arundicanea & 11 & 981 & 946.53 & $<0.001$ \\
\hline Bidens cernua & 92 & 3 & 81.52 & $<0.001$ & Bidens cernua & 38 & 250 & 154.59 & $<0.001$ \\
\hline Eleocharis palustris & 148 & 5 & 131.79 & $<0.001$ & Eleocharis palustris & 22 & 53 & 12.00 & $<0.001$ \\
\hline Salix lucudua lasiandra & 198 & 9 & 170.74 & $<0.001$ & Salix lucudua lasiandra & 28 & 148 & 80.48 & $<0.001$ \\
\hline Ludwigia palustris & 72 & 31 & 15.53 & $<0.001$ & Ludwigia palustris & 37 & 471 & 369.07 & $<0.001$ \\
\hline Cyperus sp. & 78 & 9 & 53.15 & $<0.001$ & Cyperus sp. & 56 & 73 & 1.98 & $<0.001$ \\
\hline Veronica sp. & 0 & 1 & 0.00 & 1 & Veronica sp. & 0 & 36 & 34.03 & $<0.001$ \\
\hline \multicolumn{5}{|c|}{ Phalaris arundinacea $: 0.1 \mathrm{~m}$ Full } & \multicolumn{5}{|c|}{ Persicaria amphibia : 0.1m Full } \\
\hline \multicolumn{5}{|c|}{2003 vs 2016} & \multicolumn{5}{|c|}{2003 vs 2016} \\
\hline Species & $\begin{array}{c}\text { Replaced } \\
\text { RCG }\end{array}$ & $\begin{array}{c}\text { Replaced } \\
\text { By RCG }\end{array}$ & $\begin{array}{l}\text { Chi- } \\
\text { squared }\end{array}$ & p-value & Species & $\begin{array}{c}\text { Replaced } \\
\text { SW }\end{array}$ & $\begin{array}{c}\text { Replaced } \\
\text { By SW }\end{array}$ & Chi-squared & p-value \\
\hline Eragrostis hypnoides & 181 & 0 & 179.01 & $<0.001$ & Eragrostis hypnoides & 57 & 0 & 55.02 & $<0.001$ \\
\hline Persicaria sp. & 2876 & 49 & 2730.40 & $<0.001$ & Philaris arundicanea & 49 & 2876 & 2730.40 & $<0.001$ \\
\hline Bidens cernua & 27 & 29 & 0.02 & 0.8937 & Bidens cernua & 47 & 626 & 496.41 & $<0.001$ \\
\hline Eleocharis palustris & 124 & 22 & 69.87 & $<0.001$ & Eleocharis palustris & 40 & 230 & 132.20 & $<0.001$ \\
\hline Salix lucudua lasiandra & 781 & 17 & 729.54 & $<0.001$ & Salix lucudua lasiandra & 152 & 179 & 2.04 & 0.153 \\
\hline Ludwigia palustris & 618 & 70 & 434.90 & $<0.001$ & Ludwigia palustris & 68 & 1493 & 1299.00 & $<0.001$ \\
\hline Cyperus sp. & 26 & 43 & 3.71 & $<0.001$ & Cyperus sp. & 25 & 314 & 244.67 & $<0.001$ \\
\hline Veronica sp. & 0 & 2 & 0.50 & 0.4795 & Veronica sp. & 0 & 157 & 155.01 & $<0.001$ \\
\hline \multicolumn{5}{|c|}{ Phalaris arundinacea : $0.1 \mathrm{~m}$ Part } & \multicolumn{5}{|c|}{ Persicaria amphibia : 0.1m Part } \\
\hline \multicolumn{5}{|c|}{2003 vs 2016} & \multicolumn{5}{|c|}{2003 vs 2016} \\
\hline Species & $\begin{array}{c}\text { Replaced } \\
\text { RCG }\end{array}$ & $\begin{array}{c}\text { Replaced } \\
\text { By RCG }\end{array}$ & $\begin{array}{l}\text { Chi- } \\
\text { squared }\end{array}$ & $p$-value & Species & $\begin{array}{c}\text { Replaced } \\
\text { SW }\end{array}$ & $\begin{array}{c}\text { Replaced } \\
\text { By SW }\end{array}$ & Chi-squared & $p$-value \\
\hline Eragrostis hypnoides & 3 & 0 & 1.33 & 0.2482 & Eragrostis hypnoides & 0 & 0 & NA & NA \\
\hline Persicaria $s p$. & 931 & 0 & 929.00 & $<0.001$ & Philaris arundicanea & 0 & 931 & 929.00 & $<0.001$ \\
\hline Bidens cernua & 208 & 0 & 206.00 & $<0.001$ & Bidens cernua & 16 & 269 & 222.82 & $<0.001$ \\
\hline Eleocharis palustris & 278 & 0 & 276.00 & $<0.001$ & Eleocharis palustris & 0 & 0 & NA & NA \\
\hline Salix lucudua lasiandra & 696 & 0 & 694.00 & $<0.001$ & Salix lucudua lasiandra & 51 & 46 & 0.16 & 0.6846 \\
\hline Ludwigia palustris & 630 & 0 & 628.00 & $<0.001$ & Ludwigia palustris & 46 & 337 & 219.58 & $<0.001$ \\
\hline Cyperus sp. & 140 & 0 & 138.01 & $<0.001$ & Cyperus sp. & 13 & 80 & 46.84 & $<0.001$ \\
\hline Veronica sp. & 0 & 0 & NA & NA & Veronica sp. & 0 & 51 & 49.02 & $<0.001$ \\
\hline
\end{tabular}




\section{DISCUSSION}

Water Level Management

The water control structure (WCS) has successfully altered water levels within Smith and Bybee Wetlands (SBW) to more accurately reflect historic flooding patterns since it was installed in 2003. This pattern of sustained higher water levels from winter to late spring and substantially lower water levels from late summer through fall are more representative of the likely historic hydrologic regime within SBW. Stream flow monitoring of the Columbia River dating back to 1878 has shown that historic peak stream flow occurred between May-July, and has since been reduced primarily due to anthropogenic flood control measures (Figure 2, Bottom et al. 2005). Current annual water elevation patterns on the Columbia as seen in the 2015-2016 hydrographs (Figure 4) do not reflect this pattern. Water elevations now often peak much earlier in the year, and are overall less variant. However, the years of active water management showed flooding patterns more similar to historic stream flow patterns with water elevations remaining high and often peaking in May-July. This understanding of historic hydrologic fluctuations within the Columbia River has provided a conceptual model for water management in SBW, but it has also required some adjustment over the years.

The Farrelly study (2009) found that the amount and length of inundation within SBW may have been denying some species the number of non-inundated days required for them to complete their full phenological cycles, and that a reduction in the overall number of days of inundation may benefit these species and diversity within SBW overall. This resulted in managers at SBW adapting their management approach by reducing the amount of time water was retained within SBW. This late season drawdown period was, on average, almost half a month (14.57 days) shorter in the latter years of active water management (2010-2014). 
Our examination of the difference in water levels between the gauge located within SBW and the gauge on the Columbia River main stem also showed an overall reduction in the amount of water the WCS was retaining in SBW compared to Columbia River water levels during retention periods (Appendix B). A majority of the later active management years (20102014) saw overall higher water levels within the Columbia River, and SBW experienced more events in which water levels were so high that they completely inundated the WCS for periods of time. These were also La Niña years according to the EI Niño Southern Oscillations (ENSO) and years in which the Pacific Decadal Oscillations (PDO) was colder than average, the combination of which often results in larger snow packs and above average spring water elevations in the Columbia River (Bottom et al. 2005, Northwest Fisheries Science Center 2017). These factors contributed to this overall reduced difference in water levels. Therefore it appears that the overall reduction in total inundation from $211.56 \mathrm{ft}$ on average in $2003-2009$ down to $117.9 \mathrm{ft}$ on average in $2010-2014$ was not driven entirely by adaptive management efforts, but rather by a combination of reduced late season drawdown periods and higher average water levels within the Columbia River main stem. Future active management of the WCS could benefit by taking into account this variability within the Columbia River and how it may change in the future due to climate change and interannual climatic patterns such as the PDO and ENSO when planning drawdown periods to minimize excessive water retention. This would likely require a forecast based on winter precipitation conditions and coordination with Columbia River dam managers.

Active management of the WCS was halted after the drawdown period was completed in 2014 to make improvements and update safety features. This inactive management regime within SBW that no longer retained water during late winter and spring saw much lower water levels following initial high winter flows in the Columbia. These lower water levels occurred during all species' growing seasons, which could greatly affect the growth patterns of many species within SBW. 


\section{Diversity}

We observed overall declines in diversity within SBW similar to those observed in the Farrelly study (2012). This is an indication that changes in water management that have occurred since 2009 have not altered the overall pattern of declining diversity since 2003. This pattern was likely driven by two main factors: (a) one dominant monotypic species outcompeted other species' establishment and (b) higher inundation levels reduced the establishment potential of many species.

Phalaris arundinacea, which was the dominant species in 2003 and 2004, has been well documented as a species whose presence in a community often leads to reduced diversity within the site (Green and Galatowitsch 2002, Werner and Zedler 2002, Houlahan and Findlay 2004, Kercher and Zedler 2004, Schooler et al. 2006, Jenkins et al. 2008, Farrelly 2012, Kidd and Yeakley 2015). This is, in part, due to its ability to form dense, monotypic stands by reproducing vegetatively early in the growing season, which chokes out other species and makes species establishment rather difficult. While Phalaris presence has steadily declined over the years, it has been replaced in many of the locations it used to inhabit by Persicaria amphibia; another monotypic, opportunistic species with a similar life history strategy, albeit a native species to this area (Carter and Grace 1990, Partridge 2001). Persicaria now occupies even more overall percent cover than Phalaris did in 2003, which is likely a determinant factor in the overall reduction in diversity. This can be seen in the negative correlation we found between diversity and Persicaria presence, as well as the increased diversity in areas outside of Persicaria monocultures. While this increase in diversity outside of monocultures is notable, it is still significantly lower than previous years which suggests that dominant species presence isn't the only factor driving diversity downward.

It is likely that the increased water elevations during active water management have also caused a drop in diversity since 2003. These increased water elevations during portions of the 
year resulted in elevation zones becoming inundated that likely did not experience inundation for years prior to 2003. Previous studies have found that species that often do best in inundated conditions are those that reproduce vegetatively, such as Phalaris and Persicaria, and that overall seed bank expression is often reduced (Carter and Grace 1990, Jurik et al. 1994, Baldwin et al. 2001, Partridge 2001, Peterson and Baldwin 2004). This has been found to lead to conditions such as that seen in SBW where one or two species become dominant throughout the site (van der Valk et al. 1994, Nielsen and Chick 1997, Barrett et al. 2010). Therefore, it is likely that the increased water elevations hindered the establishment of some species, especially in earlier years of active management when inundation periods were longer. The shorter inundation periods in latter years appear to have benefitted species who shifted to higher elevation ranges or withstood the increased inundation in 2008 and 2009, but these shorter periods have not resulted in substantial reintroductions of species that were extirpated from the study area since 2003. They have however resulted in the recruitment of other species with similar growth patterns that were not observed in earlier years, but this number of recruited species is less than the number of extirpated species.

When we examined the diversity of only native species we observed that, while diversity of native species declined, the overall decline was less than that observed in all species. The decline in all species has been caused by slight declines in both native and non-native species, as well as a decrease in the number of species whose native status was unknown. While both natives and non-natives have been declining, the percentage of all species that are natives has been increasing slightly over the years while non-native percentage has declined, which is encouraging from a management perspective. However, further investigation into these trends is necessary to fully understand this relationship between native and non-native species and diversity. 


\section{$\underline{\text { Percent Cover }}$}

Phalaris arundinacea L. (reed canarygrass) and Persicaria sp. (smartweed)

The Farrelly study (2012) found that Phalaris, which was the dominant species on site in 2003 and 2004, was replaced by native Persicaria as the dominant species by 2008, and we found a continuation of this overall trend in dominant species replacement to be ongoing in SBW. Phalaris continued to decline at a steady pace, and while it actually saw some increases in higher elevations in 2009 , it has since shown patterns of decline across all elevations. Persicaria continued to increase in cover across all elevations it occupied in 2009. This pattern of Persicaria growth corresponds to previous studies that have found Persicaria to be a quite adept, competitive species in flooded conditions that responds very well to increased water levels similar to the actively managed water regime in SBW (Mitchell 1976, Carter and Grace 1990, Partridge 2001). The two years of inactive water management, in which water elevations were lower than previous years for a majority of these species' growing seasons, have not resulted in conditions that have shifted these overall growth patterns. This, along with Persicaria's population growth rate beginning to level out since 2009 , suggest that this ecosystem may be approaching a stable state in which Persicaria will remain the dominant species on site unless otherwise perturbed.

Our finding that Phalaris has declined across all elevations regardless of inundation levels is important because it refines the findings in the Farrelly study (2012) that Phalaris had only declined significantly in areas that had experienced at least $1.97 \mathrm{ft}(0.6 \mathrm{~m})$ of inundation. This finding in itself was a refinement of the Jenkins et al. study (2008) that found Phalaris only reduced significantly in areas that experienced $2.62 \mathrm{ft}(0.8 \mathrm{~m})$ of inundation after the first year of active water management. It appears that 11 years (2004 - 2014) of prolonged inundation during the early and mid-growing season was enough to effectively reduce Phalaris presence across all elevations in our study area regardless of inundation levels. Heavy-handed inundation 
in earlier years (2004-2009) was effective at reducing the dominance of Phalaris, and it continued to decline even in more recent years that have experienced less inundation. This suggests that, once Phalaris dominance has been reduced, yearly inundation levels can be lowered if need be to address other management issues (such as decreased native species cover) without experiencing a resurgence in Phalaris cover. It should be noted that these years of less inundation overall still experienced moderate to high levels of inundation during Phalaris' early growing season, which presumably hindered its ability to germinate or grow before other species had the opportunity to do so. Phalaris repopulation was likely also hindered by the increased presence of Persicaria, which significantly replaced Phalaris in a majority of the locations that Phalaris occupied in 2003.

This reduced presence of Phalaris, as well as the continued dominance of Persicaria, is also reflected in our analysis of these co-dominant species interactions with other common species within SBW. Persicaria has continued to expand its presence, significantly replacing all other species since 2003 except for Salix. Phalaris, conversely, has been replaced in significant amounts by all other common species in SBW. This supports the investigation into the phenological response of Phalaris to increased flooding done by the Jenkins study (2008) that found the first year of flooding negatively impacted the overall vigor of this species. The continued increased inundation has theoretically continued to reduce the vigor of Phalaris until it was no longer able to outcompete common native species on site, in particular Persicaria. The overall continued dominance of Persicaria and significant replacement of Phalaris by other common species also suggests that this ecosystem may be approaching a new, Persicariadominated, stable state that is more advantageous for native wetland vegetation than it is for Phalaris. 


\section{Overall cover change}

Many of the most common ( $\geq 5 \%$ cover) species that have been surveyed in SBW have experienced significant increases in overall cover since 2009. This is in contrast to the Farrelly study (2012) that found many of these species had declined in overall cover since 2003. The species that have responded most favorably are native obligate, emergent, herbaceous wetland species: Bidens cernua, Eragrostis hypnoides, Eleocharis palustris, and a Cyperus sp. All of these species saw the greatest increases along transects in the low elevation range of $6 \mathrm{ft}-6.6 \mathrm{ft}$ $(1.83 \mathrm{~m}-2.01 \mathrm{~m})$, which is also the lowest portion of Persicaria's overall range at SBW where its presence is lessened compared to higher elevations. This suggests that, while Persicaria is likely out-competing these species in intermediate elevations, these species are still able to establish themselves in significant numbers below Persicaria's most dominant elevation zone.

Salix lucida lasiandra (Pacific willow) is another important species in our study, in that it was the most common species in SBW outside of the co-dominant Phalaris and Persicaria, and one of the only species that has increased in percent cover every year since 2003. This is also the only species that has not been replaced significantly by Persicaria since 2003 . The Farrelly study (2012) noted an overall shift in its elevation range towards higher elevations, but it has since expanded its elevation range and increased most substantially in lower elevations between 2009 and 2016 that experienced less inundation compared to pre-2009 water elevations. Similar patterns have been seen in other studies, suggesting that this species prefers dryer conditions overall (Keddy and Fraser 2000, Timoney and Argus 2006). The earlier drawdown periods in later years of active WCS management, followed by two years of much earlier drawdowns due to inactive management, have likely driven this expansion into lower elevations zones due to longer non-inundated periods in these zones.

Outside of the most common species, overall species change within SBW has been characterized by reduced species richness (primarily in non-native species) and a shift in community composition. Many of the rarer species that were observed in 2003 have since 
disappeared from our study area. This pattern was also observed in the Farrelly study (2012), which is in line with other studies that have found that without active management techniques such as seeding or planting, restoration efforts often fail to restore a full range of species (Galatowitsch and van der Valk 1996, Mulhouse and Galatowitsch 2003, Nedland et al. 2007, Gerard et al. 2008a, Gerard et al. 2008b, and Hall and Zedler 2010). However, while many species have dropped out of the system, a number of other species have since been recruited. Less than half of the species that were observed in 2003 were also present in 2016 . These shifts in composition have not appeared to favor species of one life history strategy over another, as evident in the similar number of obligate and facultative wetland species and annual/perennial species that have dropped out vs those that have been recruited. The majority of species that were present in both 2003 and 2016 were perennial native species, indicating conditions in SBW have been most advantageous for native species that can withstand multiple years of shifting hydrology.

It is unknown how many of the recruited species were present in the seed bank and how many have been introduced to the site through dispersal from neighboring locations. Further investigation into how species are being recruited, such as an examination of the seed bank at SBW, could help to elucidate what factors are driving these large shifts in community composition. A seed bank study could also indicate how much of a presence Phalaris still has in the seed bank throughout the site, and the potential for it to repopulate areas it no longer inhabits. Additionally, an examination of plant communities in nearby locations could aid in understanding the potential for species to be introduced via seed dispersal. It is difficult to determine how to prevent the loss of more native species and encourage recruitment of other natives unless we know how these new species have emerged in SBW. 


\section{Cover Change and Maximum Inundation}

The pattern of earlier drawdown of the WCS followed by two years of inactive management led to very different inundation patterns in 2015 and 2016 compared to what was observed before or during active water management. Inundation depths were much lower earlier in the year during 2015 and 2016, which may to have been advantageous for many common herbaceous species. This can be seen in the much lower maximum inundation depth during the first two months of many species' growing seasons, especially species whose growing seasons don't begin until May or June. Many of these species (Bidens cernua, Eleocharis palustris, Eragrostis hypnoides, Cyperus sp.) are the same species that experienced substantial increases in cover in lower elevations, suggesting that these decreased inundation depths and earlier drawdowns were beneficial for the establishment and propagation of these species in this lower zone.

This pattern can also be seen in the increase in annual obligate wetland species in 2016 compared to 2009. Many of these annual obligate wetland species are ones that are commonly found in marshy shore or wet prairie ecosystems, which are often characterized by shallow standing water or moist soil conditions (Guard 1995). The high water elevations and later drawdown during earlier years of active WCS management likely resulted in conditions that were too inundated for these species to germinate during the early portion of their growing seasons, which led to declines in annual obligate wetland species from 2003 to 2009 . However, the inactive management in 2015 and 2016 generated shallow standing water and moist soil conditions in low elevations earlier in the growing season, which likely resulted in a substantial increase in annual obligate wetland species cover in these areas.

Species with growing seasons that begin earlier in the spring (March - April) experienced higher inundation depths during the first two months of their growing seasons in 2015 and 2016 that were comparable to depths during those same months in active management years. Phalaris and Persicaria, both of which have the earliest growing seasons of 
any common species in SBW (March-April) both exhibited overall growth patterns similar to those seen in 2009 , suggesting that these minimal changes in early growing season water levels may not be substantial enough to offset their already established growth trends.

Salix has the second earliest beginning to its growing season starting in April. Unlike Phalaris and Persicaria, this species expanded its range into lower elevations where it experienced dramatic increases in cover compared to 2009 , despite similar high early growing season inundation depths in 2009 and 2016. Being a perennial, woody species with a long vegetative growing season, this species is likely more affected by the overall, interannual shifting trend of reduced annual inundation periods in SBW rather than only early growing season two-month inundation trends. Much lower water levels for a majority of 2015 and 2016 were likely very advantageous for Salix and drove a lot of this expansion into lower elevation zones.

Overall, reduced summer water levels from earlier drawdowns of the WCS from 2010 to 2014 followed by two years of inactive management appear to have led to many species shifting or expanding their ranges into lower elevations. We noted this observationally as well. Many low elevation areas that were noted in the Farrelly study (2012) as exposed mudflats in 2008 and 2009 were dense fields of primarily emergent, herbaceous species during our field seasons.

We used maximum inundation depth as the variable in this analysis due to its nearly 1-to-1 correlation with duration of inundation. Due to the nature of this study we cannot, however, determine which if either of these variables is more important for species establishment and propagation within SBW. Outside of a laboratory experimental design, we are unable to account for the large number of variables that may affect species growth in-situ. Also, different variables may be more or less important for different species. Previous studies have shown that depth of inundation, rather than duration, is likely more important to the establishment and overall growth of Phalaris and other herbaceous perennials (Crawford 2003, Herr-Turoff and Zedler 2006, Jenkins et al. 2008). Conversely, other species such as Salix and 
some herbaceous species have been found to require a substantial duration of non-inundated conditions to successfully complete a full phenological growth cycle (Keddy and Reznicek 1986, Keddy and Fraser 2000, Crawford 2003, Timoney and Argus 2006, Jenkins et al. 2008). Therefore, without a mechanistic analysis of the physiological stresses placed on these species by either prolonged or deep inundation, we are unable to conclude that one variable or another is driving the species changes within SBW, and can only report with confidence on the overall patterns we have observed.

\section{Conclusion / Management Implications}

The water control structure was installed in SBW in 2003 with the goal of reducing Phalaris presence and supporting native vegetation. Since then, Phalaris has steadily declined in cover across the entirety of our study area. Native Persicaria has taken advantage of this and successfully replaced Phalaris as the dominant species on site. This shift in dominant species presence, along with increased water elevations within SBW, have resulted in a portion of the rarer species in SBW being extirpated from our study area and other species being recruited, albeit in fewer numbers. This has resulted in an overall decrease in species richness and diversity (primarily of non-native species) over the period of this study.

Earlier drawdowns of water elevations during later active management years of the WCS, as well as two years of inactive management in which water elevations were substantially lower compared to years of active management, has resulted in the increased presence of multiple common native obligate species in SBW. These increases were most common in lower elevations. This suggests that these longer dry periods have been beneficial for some species that were driven to higher elevations or decreased in overall cover during years of more heavy handed management. It would benefit managers to be aware of these patterns and consider 
increasing the number of low water elevation days for species to be able to complete their full phenological cycles during their growing seasons. That being said, increased inundation during the early and mid-growing season has been beneficial at reducing Phalaris presence.

This fine-tuning of when to draw down water levels and by how much is the key issue in vegetation management in SBW. Retaining high water levels in the early growing season months (April - May) has been able to suppress Phalaris without having a negative effect on other common species with early growing seasons such as Persicaria and Salix, and lower water levels by May or June have greatly benefitted annual herbaceous obligate wetland species. Therefore, it may be beneficial to begin drawdown in April or May in active management years, as long as Columbia River water levels are low enough to allow it. Managers could also apply multiple years of inactive water management, as the extended dry period has been seen to be quite beneficial for many native and annual obligate wetland species. There is a risk that Phalaris could reoccupy lower elevation zones in these drier conditions, so active management periods should continue to be used to reduce its overall presence and vigor.

Based on our experience, a future management strategy to continue to reduce Phalaris presence while supporting native vegetation would be to use cycles of active management for 4 to 5 years, drawing water levels down by May or early June when possible, followed by 2 to 3 years of inactive management. This is dependent on water levels within the Columbia River during these years. If water elevations in the Columbia are above the height of the WCS into late spring or even summer, as was seen in 2011, then May-June WCS drawdown will not be possible. If water elevations are lower than the WCS by May, then active water drawdown will be most effective. Inactive water management years may be most effective during years of moderate low flow on the Columbia to allow for long drier periods that don't become too dry for obligate wetland species. It should be noted that the effects of inactive management that we observed are only based on two preliminary years of inactive management following 11 years of 
active management. We can only project, based on our experience during this 13-year study, how future patterns of inactive management may affect this system. Future monitoring and adaptive management will be required to better understand how well these management methods address future climate and river conditions.

Planning management patterns based on climatic patterns such as the El Niño Southern Oscillation (ENSO) and Pacific Decadal Oscillation (PDO) could aid in anticipating water levels. The wettest years of our study (2010-2012) occurred during La Niña years combined with a colder than average PDO. Inactive management years of 2015 and 2016 were EI Niño years with warmer than average PDO. It should be noted however that future projections of ENSO and PDO patterns, especially for multiple years into the future, may not be entirely accurate and made additionally complex due to climate change uncertainties (Bottom et al. 2005, Northwest Fisheries Science Center 2017). However, ambitious efforts have already been made in these regards (Markoff and Cullen 2008) and future efforts to refine these predictions are possible and would be highly valuable. Cooperation with the Army Corps of Engineers may aid in anticipating water elevations as well because they control the dams along the main stem of the Columbia and therefore actively control water elevations that directly affect SBW.

Continued vegetation monitoring efforts are critical to furthering our understanding of the long-term relationships between wetland vegetation and hydrology. It's also vital from a management perspective in tracking long term shifts in non-native species such as Phalaris and informing future management efforts at SBW. Phalaris has been substantially reduced in SBW thanks to this long term adaptive management regime. The fact that Phalaris cover has been reduced by well over half of what it was in 2003 through hydrologic management alone is quite outstanding. It's vital that this adaptive management continue into the future because Phalaris will most likely persist at some level on site. Hydrologic management cycles of 4 to 5 years of active management followed by 2 to 3 years of inactive management will likely continue to 
suppress Phalaris and encourage native wetland species growth and diversity, and continued vegetation monitoring will be necessary to validate these assumptions. Additional monitoring efforts such as a seed bank analysis and examining neighboring wetland plant communities could also better inform future management in regards to how this community composition is shifting over time.

Our understanding of this wetland vegetation community and the effects of hydrologic management would not have been possible without a long-term monitoring effort and the willingness and ability by managers to adapt management strategies for over a decade. This has only been possible thanks to the cooperation and coordination between the Yeakley lab at Portland State University and the Stewart team at Metro, who have been working together for 15 years to understand, protect, and enhance this high quality wetland ecosystem while also advancing the scientific understanding of wetland ecology and management. It is a testament to what can be achieved when restoration practitioners and the academic community work together, and an important example given the number of difficulties natural resource scientists and practitioners already experience. This type of understanding and long term management is vital for future wetland management and restoration, especially given the incredibly large number of wetlands we have already lost over the last century and the impending threat of climate change. As entire regions are expected to experience dramatic shifts in precipitation and hydrology, we must be able to act to the best of our abilities to preserve and restore these vitally important and productive ecosystems. 


\section{REFERENCES}

Adams, C.R. and Galatowitsch, S.M. 2005. Phalaris arundinacea (reed canary grass): rapid growth and growth pattern in conditions approximating newly restored wetlands. Ecoscience 12(4): 569-573.

Allen, C.R., and Gunderson, L.H. 2011. Pathology and failure in the design and implementation of adaptive management. Journal of Environmental Management 92: 1379-1384.

Apfelbaum, S.I., and C.E. Sams. 1987. Ecology and control of reed canarygrass (Phalaris arundinacea L.). Natural Areas Journal 7:69-74.

Baldwin, A.H., Egnotovich, M.S., and Clarke, E. 2001. Hydrologic change and vegetation of tidal freshwater marshes: field, greenhouse, and seed-bank experiments. Wetlands 21(4): 519-531.

Barclay, A.M. and R.M.M. Crawford. 1982. Plant growth and survival under strict anaerobiosis. Journal of Experimental Botany Vol 33 No 134 pp. 541-549.

Barrett, R., Nielsen, D.L., Croome, R. 2010. Associations between the plant communities of floodplain wetlands, water regime and wetland type. River Research and Applications 26: $866-876$.

Borja, A., Dauer, D.M., Elliott, M., Simenstad, C.A. 2010. Medium- and long-term recovery of estuarine and coastal ecosystems: patterns, rates, and restoration effectiveness. Estuaries and Coasts 33(6): 1249-1260.

Bottom, D.L., C.A. Simenstad, J. Burke, A.M. Baptista, D.A. Jay, K.K. Jones, E. Casillas, and M.H. Schiewe. 2005. Salmon at river's end: the role of the estuary in the decline and recovery of Columbia River salmon. U.S. Dept. Commer., NOAA Tech. Memo. NMFSNWFSC- 68, 246 p. 
Brower, J. E., J. H. Zar, and C. N. von Ende. 1997. Field and Laboratory Methods for General Ecology, 4th edition. WCB/McGraw-Hill, Boston, MA, USA.

Buijse, A. D., Coops, H., Staras, M., Jans, L.H., Van Geest, G. J., Grift, R.E., Ibelings, B.W., Oosterberg, W., and Roozen, F.C.J.M. 2002. Restoration strategies for river floodplains along large lowland rivers in Europe. Freshwater Biology 47: 889-907.

Carter, M.F. and Grace, J.B. 1990. Relationships between flooding tolerance, life history, and short-term competitive performance in three species of Polygonum. American Journal of Botany 77(3): 381-387.

Christy, J.A. 2004. Native freshwater wetland plant associations of northwestern Oregon. Oregon Natural Heritage Information Center, Oregon State University.

Compensatory Mitigation for Losses of Aquatic Resources, 40 CFR Part 230 (2008).

Convertino, M., Foran, C.M., Keilser, J.M., Scarlett, L., LoSchiavo, A., Kiker, G.A., Linkov, I. 2013. Enhanced adaptive management: Integrating decision analysis, scenario analysis and environmental modeling for the Everglades. Scientific Report 3.

Cooke, S. S. 1997. A Field Guide to the Common Wetland Plants of Western Washington and Northwestern Oregon. Seattle Audubon Society, Seattle, WA.

Coops, H. and van der Velde, G. 1995. Seed dispersal, germination and seedling growth of six helophyte species in relation to water-level zonation. Freshwater Biology 34, 13-20.

Coops, H., F. W. B. van den Brink, and G. van der Velde. 1996. Growth and morphological responses of four helophyte species in an experimental water-depth gradient. Aquatic Botany 54:11-24.

Crawford, R.M.M. 2003. Seasonal differences in plant responses to flooding and anoxia. Canadian Journal of Botany 81:1224-1246.

Dahl, T. E. 1990. Wetlands losses in the United States 1780's to 1980's. U.S. Department of the Interior, Fish and Wildlife Service, Washington, D.C. Jamestown, ND: Northern Prairie Wildlife Research Center Online. 
Dahl, T.E. 2011. Status and trends of wetlands in the conterminous United States 2004 to 2009. U.S. Department of the Interior; Fish and Wildlife Service, Washington, D.C. 108 pp.

DiTomaso, J.M. and Healy, E.A. 2003. Aquatic and Riparian Weeds of the West. University of California Agriculture and Natural Resources, Oakland, CA.

Ebberts, B.D., Zelinsky, B.D., Karnezis, J.P., Studebaker, C.A., Lopez-Johnston, S., Creason, A.M., Krasnow, L., Johnson, G.E., and Thom, R.M. 2017. Estuary ecosystem restoration: implementing and institutionalizing adaptive management. Restoration Ecology.

Farrelly, T.S. 2012. Long-term Responses of Phalaris arundinacea and Columbia River Botomland Vegetation to Managed Flooding. Master's thesis, Portland State University, 2012, Dissertations and Theses. Paper 787.

Fraser, L.H. and Karnezis, J.P. 2005. A comparative assessment of seedling survival and biomass accumulation for 14 wetland plant species grown under minor water-depth differences. Wetlands 25(3): 520-530.

Gerard, M., El Kahloun, M., Rymen, J., Beauchard, O., and Meire, P. 2008a. Importance of mowing and flood frequency in promoting species richness in restored floodplains. Journal of Applied Ecology 45 1780-1789.

Gerard, M., El Kahloun, M., Mertens, W., Verhagen, B., and Meire, P. 2008b. Impact of flooding on potential and realized grassland species richness. Plant Ecology 194:85-98.

Galatowitsch, S.M., and van der Valk, A.G. 1996. The vegetation of restored and natural prairie wetlands. Ecological Applications 6(1) pp. 102-112.

Galatowitsch, S.M., N.O. Anderson, and P.D. Ascher. 1999. Invasiveness in wetland plants in temperate North America. Wetlands 19:733-755.

Gratani, L., Crescente, M.F., Fabrini, G., and Varone, L. 2008. Growth pattern of Bidens cernua L.: relationships between relative growth rate and its physiological and morphological components. Photosynthetica 46 (2): 179-184. 
Gratani, L., Crescente, M.F., Fabrini, G., Bonito, A., and Varone, L. 2009. Growth analysis of a reestablished population versus a natural population of Bidens cernua L. Plant Biosystems 143: 63-68.

Green, E.K. and Galatowitsch, S.M. 2002. Effects of Phalaris arundinacea and nitrate-N addition on the establishment of wetland plant communities. Journal of Applied Ecology 39 (1): 134-144.

Greet, J., Cousens, J., Webb, J.A. 2013. Seasonal timing of inundation affects riparian plant growth and flowering: implications for riparian vegetation composition. Plant Ecology 214: 81-101.

Guard, B. Jennifer. 1995. Wetland Plants of Oregon and Washington. Lone Pine Publishing, Renton, WA.

Hall, Steven J. and Joy B. Zedler. 2010. Constraints on sedge meadow self-restoration in urban wetlands. Restoration Ecology Vol 18 No 5 pp671-680.

Healy, M.T., Rojas, I.M., and Zedler, J.B. 2015. Adaptive control of Phalaris arundinacea in Curtis Prairie. Invasive Plant Science and Management 8: 363-373.

Herubin, C. A. 1982. Principles of Surveying. Reston Publishing Co., Reston, VA.

Herr-Turoff, A. and Zedler, J.B. 2006. Does morphological plasticity of the Phalaris arundinacea canopy increase invasiveness? Plant Ecology 193: 265-277.

Houlahan, J.E. and Findlay, C.S. 2004. Effect of invasive plant species on temperate wetland plant diversity. Conservation Biology 18(4): 1132-1138.

Hutcheson, K. (1970) A Test for Comparing Diversities Based on the Shannon Formula. Journal of Theoretical Biology 29: 151-154.

Jaster, Thea, Stephen C. Meyers and Scott Sundberg, eds. 2017. Oregon Vascular Plant Checklist. [Family]. http://www.oregonflora.org/checklist.php. Version 1.7. Accessed [2017-05-15]. 
Jenkins, N.J., J.A. Yeakley, and E.M. Stewart. 2008. First-year responses to managed flooding of Lower Columbia River bottomland vegetation dominated by Phalaris arundinacea. Wetlands 28:1018-1027.

Jurik, T.W., Wang, S.C., van der Valk, A.G. 1994. Effects of sedinment load on seedling emergence from wetland seed banks. Wetlands 14(3): 159-165.

Katterer, T. and Andren, O. 1999. Growth dynamics of reed canarygrass (Phalaris arundinacea) and its allocation of biomass and nitrogen below-ground in a field receiving daily irrigation and fertilization. Nutrient Cycling Agroecosystems 54: 21-29.

Keddy, P. A. and T. H. Ellis. 1984. Seedling recruitment of 11 wetland plant species along a water level gradient: shared or distinct responses? Canadian Journal of Botany 63:18761879.

Keddy, P. A. and A. A. Reznicek. 1986. Great Lakes vegetation dynamics: the role of fluctuating water levels and buried seeds. Journal of Great Lakes Research, 12(1):25-36.

Keddy, P and Fraser, L.H. 2000. Four general principles for the management and conservation of wetlands in large lakes: the role of water levels, nutrients, competitive hierarchies and centrifugal organization. Lakes \& Reservoirs: Research and Management 5:177-185.

Kercher, S.M. and Zedler, J.B. 2004. Multiple disturbances accelerate invasion of reed canary grass (Phalaris arundinacea L.) in a mesocosm study. Oecologia 138: 455-464.

Kettenring, K.M. and Adams, C.R. 2011. Lessons learned from invasive plant control experiments: a systematic review and meta-analysis. Journal of Applied Ecology 48: 970-979.

Kidd, S.A. and J.A. Yeakley. 2015. Riparian wetland plant response to livestock exclusion in the Lower Columbia River Basin. Natural Areas Journal 35(4): 504-514.

Kilbride, K.M., and Paveglio, F.L. 1999. Integrated pest management to control reed canary grass in seasonal wetlands of southwestern Washington. Wildlife Society Bulletin. 27: 292-297. 
Kuzovkina-Eischen, Yulia A. 2003. Stress Tolerance and Horticultural Evaluation of the Genus Salix. The Ohio State University Dissertation Degree Doctor of Philosophy in the Graduate School.

Lavergne, S. and Molofsky, J. 2004. Reed canary grass (Phalaris arundinacea) as a biological model in the study of plant invasions. Critical Reviews in Plant Sciences. 23: 415-429.

Lavergne, S., and Molofsky, J. 2006. Control strategies for the invasive reed canarygrass (Phalaris arundinacea L.) in North American wetlands: the need for an integrated management plan. Natural Areas Journal 26(2): 208-214.

Lefor, M. W. 1987. Phalaris arundinacea L. (reed canary grass - gramineae) as a hydrophyte in Essex, Connecticut, USA. Environmental Management 11:771-73.

Lev, E., J. Fugate, M. P. Hayes, D. Smith, L. Wilson, and R. Wissemann. 1994. The biota of Smith and Bybee Lakes Management Area. Metro, Portland, OR.

Markoff, M.S., and Cullen, A.C. 2008. Impact of climate change of Pacific Northwest hydropower. Climatic Change 87: 451-469.

Martina, J.P. and von Ende, C.N. 2012. Highly plastic response in morphological and physiological traits to light, soil- $\mathrm{N}$ and moisture in the model invasive plant, Phalaris arundinacea. Envionmental and Experimental Botany 82: 43-53.

Michener, W.K. and Haeuber, R.A. 1998. Flooding: natural and managed disturbances. BioScience 48:677-680.

Miller, R.C. and Zedler, J.B.. 2003. Responses of native and invasive wetland plants to hydroperiod and water depth. Plant Ecology. 167:57-69.

Mitsch, W J and R F Wilson. 1996. Improving the success of wetland creation and restoration with know-how, time, and self-design. Ecological Application 6:77-83.

Mitsch, W.J. and Gosselink, J.G. 2015. Wetlands of the world. Wetlands: 45-110.

Mitchell, Richard S. 1976. Submergence experiments on nine species of semi-aquatic Polygonum. American Journal of Botany 63(8): 1158-1165. 
Moorhead, K.K., Bell, D.W., and Thorn, R.N. 2008. Floodplain hydrology after restoration of a southern Appalachian mountain stream. Wetlands 28:632-639.

Molofsky, J., Morrison, S., and Goodnight, C. 1999. Genetic and environmental controls on the establishment of the invasive grass, Phalaris arundinacea. Biological Invasions. 1: 181188.

Moreno-Mateos, D., Meli, P., Vara-Rodríguez, M.I., and J. Aronson. 2015. Ecosystem response to interventions: lessons from restored and created wetland ecosystems. Journal of Applied Ecology 52: 1528-1537.

Mulhouse, J.M. and Galatowitsch, S.M., 2003. Revegetation of prairie pothole wetlands in the mid-continental US: twelve years post-reflooding. Plant Ecology 169(1): 143-159.

Nedland, T.S., Wolf, A., Reed, T. 2007. A Reexamination of restored wetlands in Manitowoc County, Wisconsin. Wetlands 27(4): 999-1015.

Nielsen, D,.and Chick, A. 1997. Flood-mediated changes in aquatic macrophyte community structure. Marine Freshwater Research 48: 153-157.

Northwest Fisheries Science Center. 2017. Ocean Ecosystem Indicators: Temperature Anomalies. Available URL:

https://www.nwfsc.noaa.gov/research/divisions/fe/estuarine/oeip/da-sea-surfacetemp.cfm\#TA-01

Nygaard, B. and Ejrnaes, R. 2009. The impacts of hydrology and nutrients on species composition and richness: evidence from a microcosm experiment. Wetlands 29(1): 187195.

Oregon Department of State Lands. 2016. A Guide To The Removal-Fill Permit Process. Salem, OR.

Patten, D.T. 2006. Restoration of wetland and riparian systems: The role of science, adaptive management, history, and values. Journal of Contemporary Water Research \& Education 134: 9-18. 
Paveglio, F.L., and Kilbride, K.M. 2000. Response of vegetation to control of reed canary grass in seasonally managed wetlands of southwestern Washington. Wildlife Society Bulletin. 28: 730-740.

Partridge, J.W. 2001. Persicaria amphibia (L.) Gray (Polygonum amphibium L.). Biological Flora of the British Isles. List Br. Vasc. PI. (1958) no. 320, 8. Journal of Ecology 89: 487-501

Peterson, J.E., and Baldwin, A.H. 2004. Seedling emergence from seed banks of tidal freshwater wetlands: response to inundation and sedimentation. Aquatic Biology 78(3): 243-254.

Raulings, E.J., Morris, K., Roache, M.C., Boon, P.I. 2010. The importance of water regimes operating at small spatial scales for the diversity and structure of wetland vegetation. Freshwater Biology 55: 701-715.

Raulings, E.J., Morris, K., Roache, M.C., Boon, P.I. 2011. Is hydrological manipulation an effective management tool for rehabilitating chronically flooded, brackish-water wetlands? Freshwater Biology 56: 2347-2369.

Rice, J. S. and B. W. Pinkerton. 1993. Reed canary grass survival under cyclic inundation. Journal of Soil and Water Conservation 48:132-35.

Sain, R.E., Fonferek, W.J., Simpson, M.S., and Whittinghill, K.W. 1984. First-year vegetation following exposure of the Edmondson lake bed, Washington County, Virginia. Castanea 49(4): 158-166.

Schooler, S.S., McEvoy, P.B., and Coombs, E.M. 2006. Negative per capita effects of purple loosestrife and reed canary grass on plant diversity of wetland communities. Diversity and Distributions 12: 351-363.

Simenstad, C., Reed, D., Ford, M. 2006. When is restoration not? Incorporating landscapescale processes to restore self-sustaining ecosystems in coastal wetland restoration. Ecological Engineering 26: 27-39. 
Stannard, M. and Crowder, W. 2001. Biology, history, and suppression of reed canarygrass (Phalaris arundinacea L.). U. S. Department of Agriculture, Natural Resources Conservation Service, Boise, ID, USA. TN Plant Materials No. 40.

Stewart, Elaine. 2017. Personal Communication. Metro Regional Government.

Sullivan, P.L., Gaiser, E.E., Surratt, D., Rudnick, D.T., Davis, S.E., and F.H. Sklar. 2014. Wetland ecosystem response to hydrologic restoration and management: The Everglades and its urban-agricultural boundary (FL, USA). Wetlands 34(1): S1-S8.

Sultan S. E. and F. A. Bazzaz. 1993. Phenotypic plasticity in Polygonum persicaria. II. Norms of reaction to soil moisture and the maintenance of genetic diversity. Evolution, 47(4), 1993, pp. 1032-1049.

Susskind, L. Camacho, A.E., and Schenk, T. 2012. A critical assessment of collaborative adaptive management in practice. Journal of Applied Ecology 49: 47-51.

Tanner, C.D., J.R. Cordell, J. Rubey, and L. Tear. 2002. Restoration of freshwater intertidal habitat functions at Spencer Island, Everett, Washington. Restoration Ecology 10:564576.

Thorslund, J., Jarsjö, J., Jaramillo, F., Jawitz, J.W., Manzoni, S., Basu, N.B., Chalov, S.R., Cohen, M.J., Creed, I.F., Goldenberg, R., Hylin, A., Kalantari, Z., Koussis, A.D., Lyon, S.W., Mazi, K., Mard, J., Persson, K., Pietroñ, Prieto, C., Quin, A., Van Meter, K., and G. Destouni. 2017. Wetlands as large-scale nature-based solutions: Status and challenged for research, engineering, and management. Ecological Engineering 108: 489-497.

Timoney, K.P. and Argus, G. 2006. Willows, water regime, and recent cover change in the Peace-Athabasca Delta. Ecoscience 13(3): 308-317.

Timson, J. 1964. Germination in Polygonum. The University of Leicester, received 10 March 1964.

Tompkins, E. L. and W. N. Adger. 2004. Does adaptive management of natural resources enhance resilience to climate change? Ecology and Society 9(2): 10. 
United States Army Corps of Engineers, Northwest Division (USACOE). 2017. Columbia River at Vancouver Stage Height Records. Available URL: http://www.nwdwc. usace.army.mil/perl/dataquery.pl

United States Army Corps of Engineers (USACOE). 2016. The National Wetland Plant List. http://wetland_plants.usace.army.mil

University and Jepson Herbaria (UC/JEPS), University of California, Berkeley. http://ucjeps.berkeley.edu/eflora/ (accessed on June 26, 2017)

Van der Valk, A, L Squires, and C Welling. 1994. Assessing the impacts of an increase in water level on vegetation. Ecological Applications 4: 525-534.

Van der Valk, A.G. 2005. Water-level fluctuations in North American prarie wetlands. Hydrobiologia 539: 171-188.

Van der Valk, A.G. and D.M. Mushet. 2016. Interannual water-level fluctuations and the vegetation of prarie potholes: Potential impacts of climate change. Wetlands 36(2): S397-S406.

Von Behren, C., Dietrich, A.E., and J.A. Yeakley. 2013. Riparian vegetation assemblages and associated landscape factors across an urbanizing metropolitan area. Ecoscience 20(4): 373-382.

Warren, R.S., Fell, P.E., Rozsa, R., Brawley, A.H., Orsted, A.C., Olson, E.T., Swamy, V., Niering, W.A. 2002. Salt marsh restoration in Connecticut: 20 years of science and management. Restoration Ecology 10:497-513.

Weiher, E., Wisheu, I.C., Keddy, P.A., and Moore, D.R.J. 1996. Establishment, persistence, and management implications of experimental wetland plant communities. Wetlands 16(2): 208-218.

Weilhoefer, C.L., Williams, D., Nguyen, I., Jakstis, K., and C. Fischer. 2017. The effects of reed canary grass (Phalaris arundinacea L.) on wetland habitat and arthropod community 
composition in an urban freshwater wetland. Wetlands Ecological Management 25: 159175.

Werner, K.J. and Zedler, J.B. 2002. How sedge meadow soils, microtopography, and vegetation respond to sedimentation. Wetlands 22: 451-466.

Westgate, M.J., Likens, G.E., and Lindenmayer, D.B. 2013. Adaptive management of biological systems: a review. Biological Conservation 158: 128-139.

Wilcox, J.C., M.T. Healy, and J.B. Zedler. 2007. Restoring native vegetation to an urban wet meadow dominated by reed canarygrass (Phalaris arundinacea L.) in Wisconsin. Natural Areas Journal 27:354-365.

Zar, J.H. 1998. Biostatistical Analysis. 4th Edition, Prentice Hall, Englewood Cliffs, NJ, USA.

Zedler, J B and J C Callaway. 1999. Tracking wetland restoration: do mitigation sites follow desired trajectories? Restoration Ecology 7:69-73. 


\section{Appendix A: Common Species Percent Cover Change}

Table A-1: Common Species Overall Percent Cover Change.

Overall percent cover of species with $\geq 5 \%$ cover in at least one monitoring year, and percent cover change since project initiation in 2003 for all three datasets. All changes in cover since 2003 were significant $(p<0.05)$ except for those indicated in bold lettering.

\begin{tabular}{|c|c|c|c|c|c|c|c|c|c|}
\hline \multicolumn{10}{|c|}{$0.5 \mathrm{~m}$} \\
\hline & \multicolumn{5}{|c|}{ Percent Cover } & \multicolumn{4}{|c|}{ Percent Cover Change Since 2003} \\
\hline & 2003 & 2004 & 2008 & 2009 & 2015 & $\begin{array}{l}2004- \\
2003\end{array}$ & $\begin{array}{c}2008- \\
2003\end{array}$ & $\begin{array}{c}2009- \\
2003\end{array}$ & $\begin{array}{c}2015- \\
2003\end{array}$ \\
\hline Persicaria sp. & $19.64 \%$ & $33.12 \%$ & $52.66 \%$ & $52.23 \%$ & $59.53 \%$ & $13.48 \%$ & $33.02 \%$ & $32.58 \%$ & $39.89 \%$ \\
\hline Philaris arundinacea & $44.71 \%$ & $42.61 \%$ & $27.51 \%$ & $28.31 \%$ & $13.92 \%$ & $-2.10 \%$ & $-17.20 \%$ & $-16.40 \%$ & $-30.79 \%$ \\
\hline Bidens cernua & $11.80 \%$ & $15.45 \%$ & $7.07 \%$ & $5.34 \%$ & $11.86 \%$ & $3.65 \%$ & $-4.73 \%$ & $-6.46 \%$ & $0.06 \%$ \\
\hline Eragrostis hypnoides & $0.00 \%$ & $4.30 \%$ & $0.02 \%$ & $2.46 \%$ & $12.53 \%$ & $4.30 \%$ & $0.02 \%$ & $2.46 \%$ & $12.53 \%$ \\
\hline Eleocharis palustris & $1.90 \%$ & $0.39 \%$ & $0.86 \%$ & $1.06 \%$ & $9.05 \%$ & $-1.51 \%$ & $-1.04 \%$ & $-0.84 \%$ & $7.15 \%$ \\
\hline Salix lucidia lasiandra & $10.80 \%$ & $14.59 \%$ & $17.35 \%$ & $14.15 \%$ & $16.75 \%$ & $3.78 \%$ & $6.55 \%$ & $3.35 \%$ & $5.94 \%$ \\
\hline Ludwigia palustris & $22.21 \%$ & $21.13 \%$ & $15.77 \%$ & $19.58 \%$ & $8.69 \%$ & $-1.08 \%$ & $-6.44 \%$ & $-2.64 \%$ & $-13.53 \%$ \\
\hline Cyperus sp. & $5.38 \%$ & $7.32 \%$ & $0.56 \%$ & $1.19 \%$ & $13.96 \%$ & $1.94 \%$ & $-4.82 \%$ & $-4.19 \%$ & $8.58 \%$ \\
\hline Veronica sp. & $3.09 \%$ & $8.49 \%$ & $2.05 \%$ & $6.03 \%$ & $0.00 \%$ & $5.40 \%$ & $-1.04 \%$ & $2.94 \%$ & $-3.09 \%$ \\
\hline \multicolumn{10}{|c|}{$0.1 \mathrm{~m}$ Full } \\
\hline & \multicolumn{5}{|c|}{ Percent Cover } & \multicolumn{4}{|c|}{ Percent Cover Change Since 2003} \\
\hline & 2003 & 2004 & 2008 & 2009 & 2016 & $\begin{array}{c}2004- \\
2003 \\
\end{array}$ & \begin{tabular}{|c|}
$2008-$ \\
2003 \\
\end{tabular} & $\begin{array}{c}2009- \\
2003\end{array}$ & $\begin{array}{c}2016- \\
2003 \\
\end{array}$ \\
\hline Persicaria sp. & $20.23 \%$ & $34.75 \%$ & $59.90 \%$ & $59.33 \%$ & $67.93 \%$ & $14.52 \%$ & $39.68 \%$ & $39.10 \%$ & $47.70 \%$ \\
\hline Philaris arundinacea & $46.50 \%$ & $47.74 \%$ & $34.43 \%$ & $36.34 \%$ & $17.56 \%$ & $1.23 \%$ & $-12.08 \%$ & $-10.16 \%$ & $-28.94 \%$ \\
\hline Bidens cernua & $9.13 \%$ & $12.33 \%$ & $5.61 \%$ & $4.03 \%$ & $6.75 \%$ & $3.20 \%$ & $-3.52 \%$ & $-5.10 \%$ & $-2.38 \%$ \\
\hline Eragrostis hypnoides & $0.00 \%$ & $4.57 \%$ & $0.01 \%$ & $2.64 \%$ & $5.34 \%$ & $4.57 \%$ & $0.01 \%$ & $2.64 \%$ & $5.34 \%$ \\
\hline Eleocharis palustris & $2.79 \%$ & $0.43 \%$ & $0.35 \%$ & $0.99 \%$ & $5.02 \%$ & $-2.36 \%$ & $-2.44 \%$ & $-1.80 \%$ & $2.23 \%$ \\
\hline Salix lucidia lasiandra & $6.38 \%$ & $9.54 \%$ & $12.67 \%$ & $11.19 \%$ & $21.14 \%$ & $3.16 \%$ & $6.29 \%$ & $4.81 \%$ & $14.75 \%$ \\
\hline Ludwigia palustris & $26.46 \%$ & $21.94 \%$ & $16.67 \%$ & $20.36 \%$ & $15.28 \%$ & $-4.53 \%$ & $-9.79 \%$ & $-6.10 \%$ & $-11.18 \%$ \\
\hline Cyperus sp. & $5.72 \%$ & $7.51 \%$ & $0.53 \%$ & $1.53 \%$ & $3.24 \%$ & $1.79 \%$ & $-5.19 \%$ & $-4.20 \%$ & $-2.48 \%$ \\
\hline Veronica sp. & $2.62 \%$ & $8.57 \%$ & $1.62 \%$ & $7.90 \%$ & $0.00 \%$ & $5.95 \%$ & $-0.99 \%$ & $5.28 \%$ & $-2.62 \%$ \\
\hline \multicolumn{10}{|c|}{$0.1 \mathrm{~m}$ Part } \\
\hline & \multicolumn{5}{|c|}{ Percent Cover } & \multicolumn{4}{|c|}{ Percent Cover Change Since 2003} \\
\hline & 2003 & 2004 & 2008 & 2009 & 2016 & $\begin{array}{l}2004- \\
2003 \\
\end{array}$ & $\begin{array}{c}2008- \\
2003\end{array}$ & $\begin{array}{c}2009- \\
2003\end{array}$ & $\begin{array}{c}2016- \\
2003\end{array}$ \\
\hline Persicaria sp. & $18.80 \%$ & $28.58 \%$ & $58.83 \%$ & $56.19 \%$ & $53.97 \%$ & $9.79 \%$ & $40.04 \%$ & $37.40 \%$ & $35.17 \%$ \\
\hline Philaris arundinacea & $56.39 \%$ & $50.64 \%$ & $35.07 \%$ & $34.87 \%$ & $17.17 \%$ & $-5.76 \%$ & $-21.32 \%$ & $-21.52 \%$ & $-39.22 \%$ \\
\hline Bidens cernua & $13.42 \%$ & $19.35 \%$ & $18.38 \%$ & $11.59 \%$ & $7.56 \%$ & $5.93 \%$ & $4.96 \%$ & $-1.83 \%$ & $-5.86 \%$ \\
\hline Eragrostis hypnoides & $0.00 \%$ & $6.03 \%$ & $0.02 \%$ & $2.36 \%$ & $0.06 \%$ & $6.03 \%$ & $0.02 \%$ & $2.36 \%$ & $0.06 \%$ \\
\hline Eleocharis palustris & $0.71 \%$ & $0.75 \%$ & $2.90 \%$ & $2.26 \%$ & $8.71 \%$ & $0.04 \%$ & $2.18 \%$ & $1.55 \%$ & $8.00 \%$ \\
\hline Salix lucidia lasiandra & $4.70 \%$ & $9.96 \%$ & $18.38 \%$ & $14.93 \%$ & $27.69 \%$ & $5.26 \%$ & $13.68 \%$ & $10.22 \%$ & $22.99 \%$ \\
\hline Ludwigia palustris & $14.73 \%$ & $24.47 \%$ & $27.21 \%$ & $35.05 \%$ & $26.32 \%$ & $9.75 \%$ & $12.49 \%$ & $20.33 \%$ & $11.59 \%$ \\
\hline Cyperus sp. & $3.67 \%$ & $4.53 \%$ & $1.11 \%$ & $1.93 \%$ & $3.59 \%$ & $0.85 \%$ & $-2.56 \%$ & $-1.75 \%$ & $-0.08 \%$ \\
\hline Veronica sp. & $3.20 \%$ & $8.79 \%$ & $6.09 \%$ & $5.02 \%$ & $0.00 \%$ & $5.60 \%$ & $2.90 \%$ & $1.83 \%$ & $-3.20 \%$ \\
\hline
\end{tabular}




\section{Appendix B: Hydrologic Management}

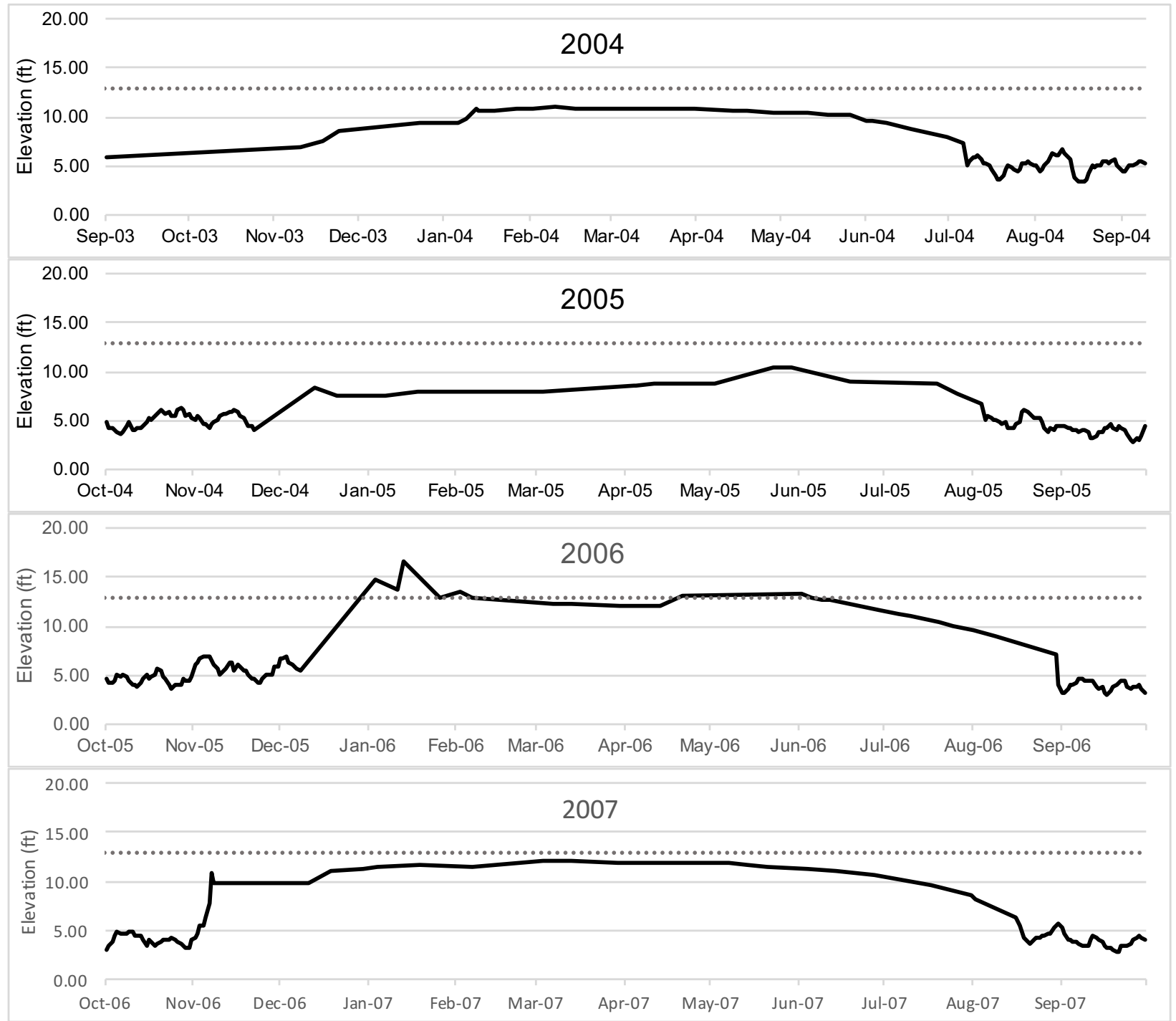

Figure B-1: Annual Hydrographs.

Water levels (NGVD29) for every water year (Oct 1 to Sept 30) since the water control structure (WCS) was installed in 2003. Water level data was obtained from weekly measurements taken at the WCS gauge. Periods in which WCS measurements were unavailable were supplemented with daily average water level data taken from a US Army Corps of Engineers gauge located near Smith and Bybee on the Columbia River (USGS-ID 14144700). The dotted line represents the height of the WCS (12.94ft) and the dashed lines represent known beaver dam elevations from multiple surveys. 


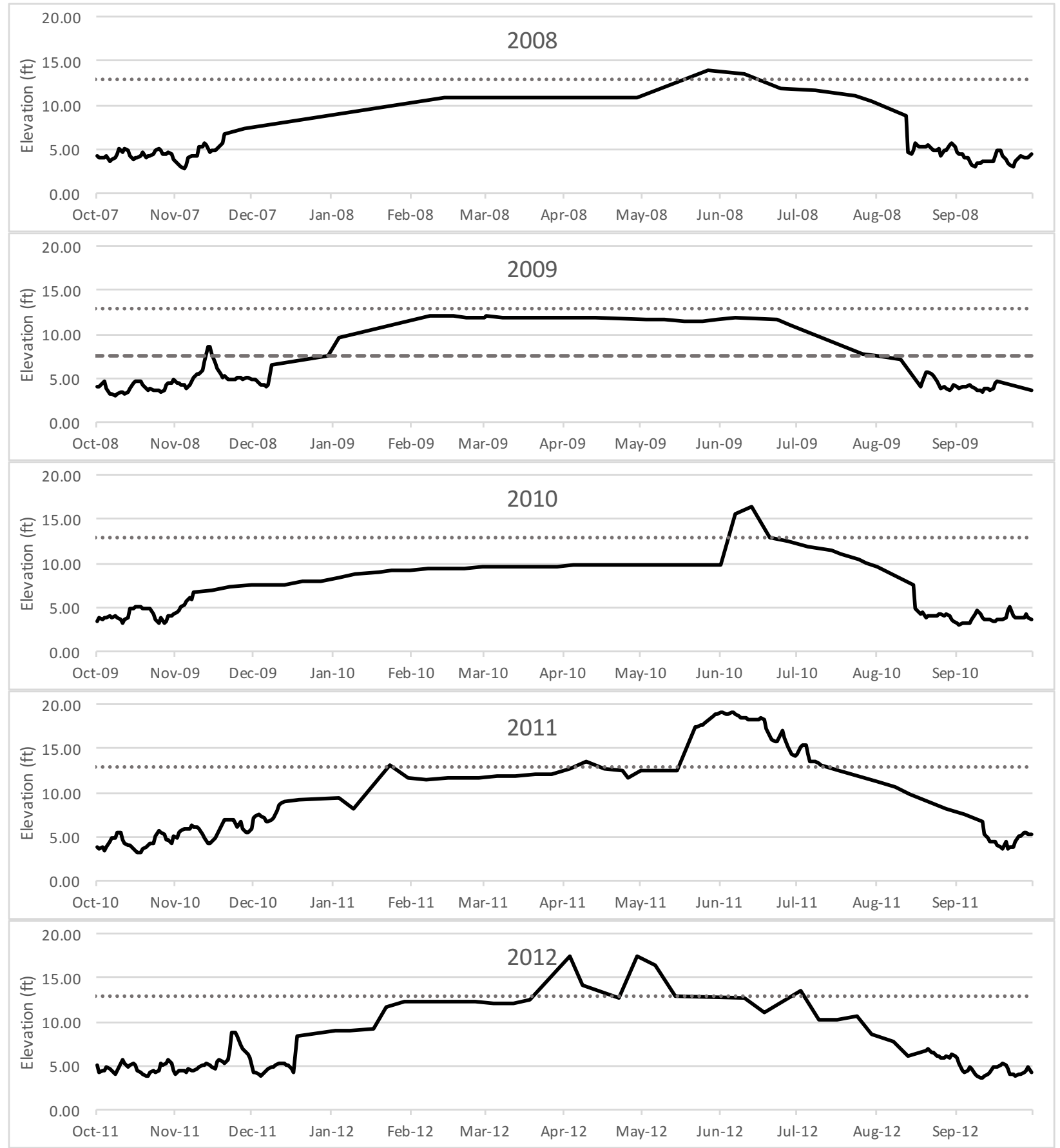

Figure B-1 continued: Annual Hydrographs.

Water levels (NGVD29) for every water year (Oct 1 to Sept 30) since the water control structure (WCS) was installed in 2003. Water level data was obtained from weekly measurements taken at the WCS gauge. Periods in which WCS measurements were unavailable were supplemented with daily average water level data taken from a US Army Corps of Engineers gauge located near Smith and Bybee on the Columbia River (USGS-ID 14144700). The dotted line represents the height of the WCS (12.94ft) and the dashed lines represent known beaver dam elevations from multiple surveys. 


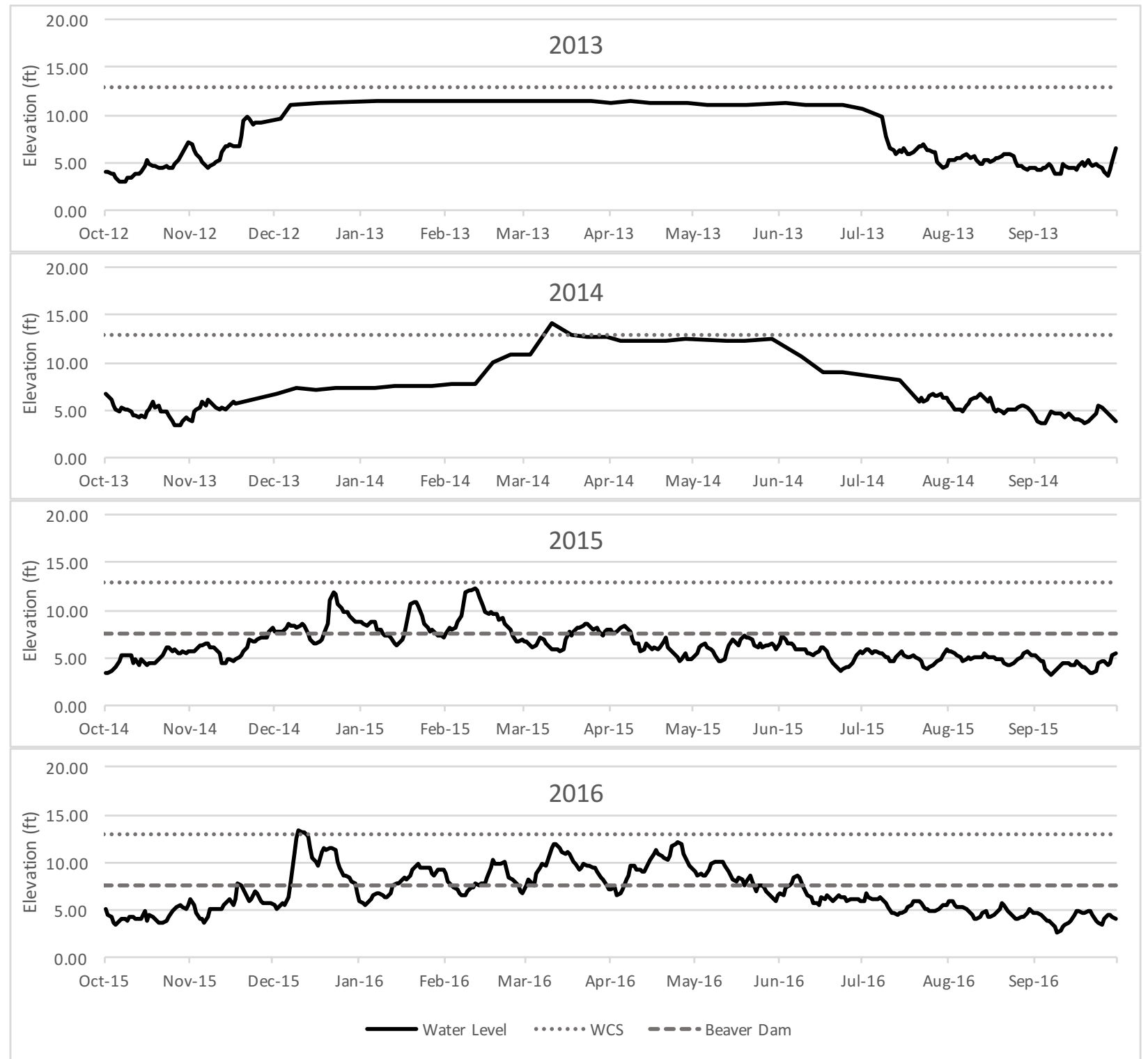

Figure B-1 continued: Annual Hydrographs.

Water levels (NGVD29) for every water year (Oct 1 to Sept 30) since the water control structure (WCS) was installed in 2003. Water level data was obtained from weekly measurements taken at the WCS gauge. Periods in which WCS measurements were unavailable were supplemented with daily average water level data taken from a US Army Corps of Engineers gauge located near Smith and Bybee on the Columbia River (USGS-ID 14144700). The dotted line represents the height of the WCS (12.94ft) and the dashed lines represent known beaver dam elevations from multiple surveys. 


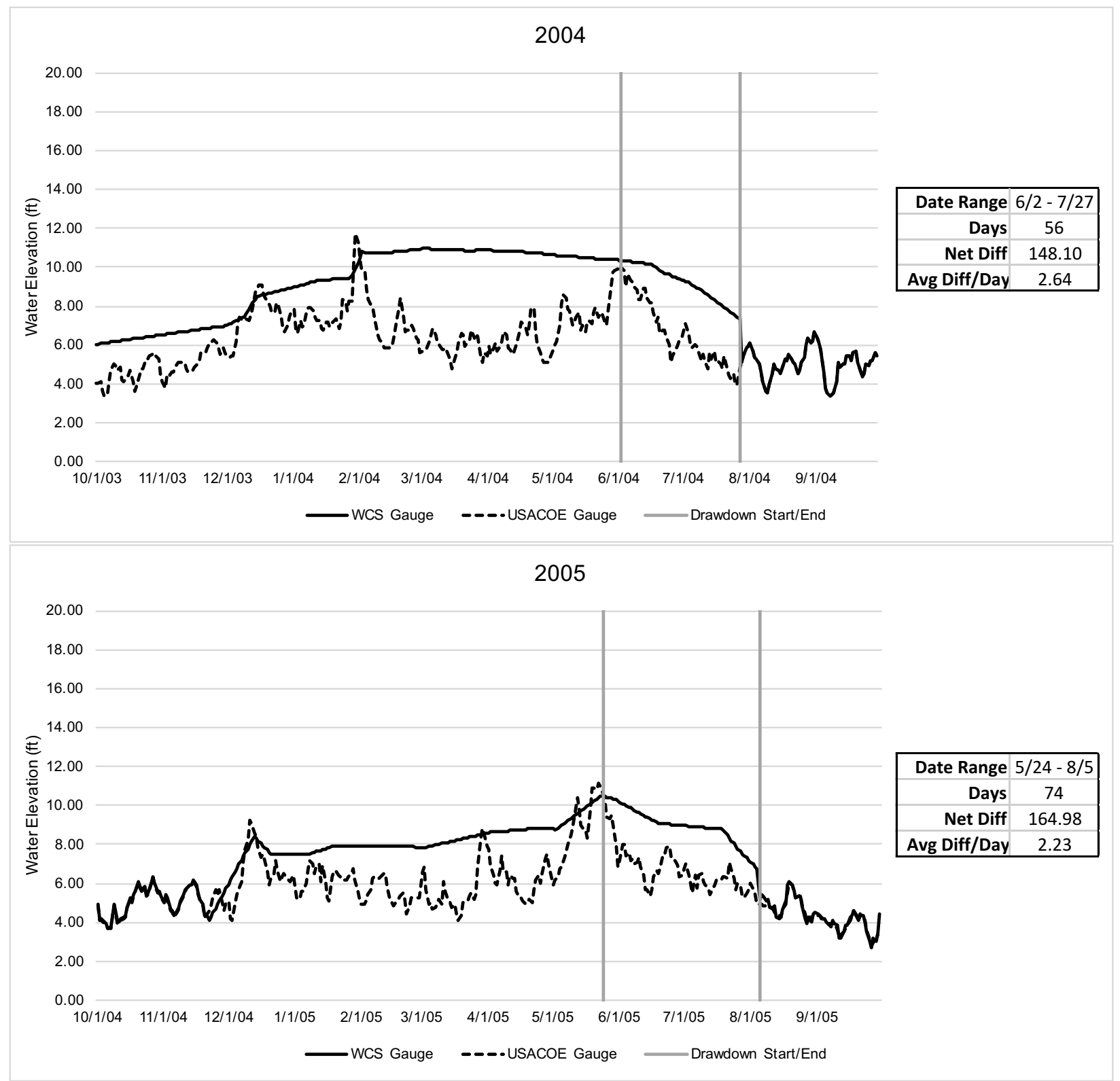

Figure B-2: Changes to Annual WCS Late Season Drawdown.

Differences between the water control structure (WCS) gauge and the USACOE gauge located on the Columbia River for every year that the WCS was used to retain water. Vertical lines indicate the period of time within each water year (Oct. 1 - Sept. 20) that is considered the late season draw down period. Summary tables to the right of each graph indicate that length of time, the overall net difference (in feet) between gauges, and the average difference in water level over this period of time. 


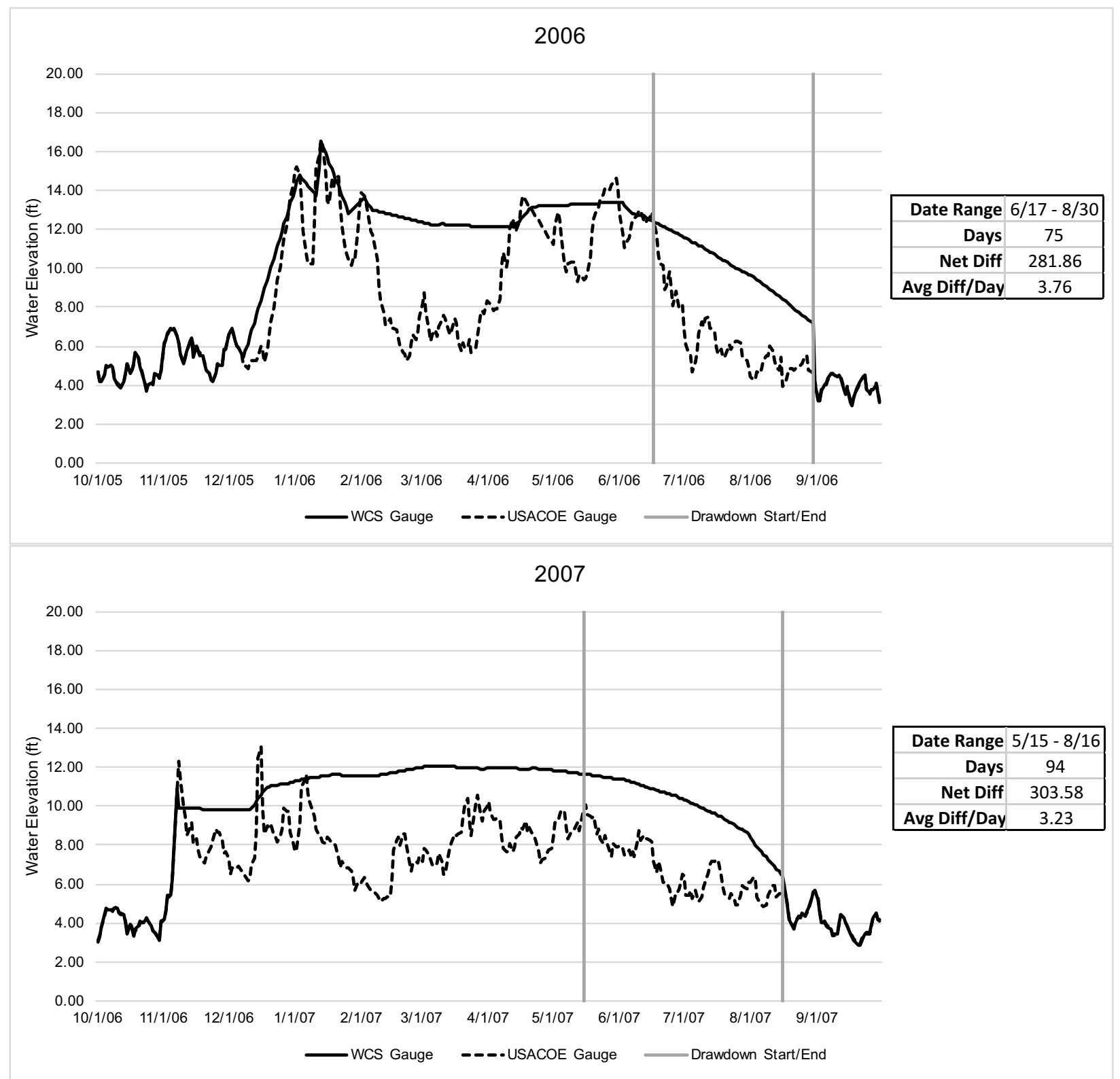

Figure B-2 continued: Changes to Annual WCS Late Season Drawdown.

Differences between the water control structure (WCS) gauge and the USACOE gauge located on the Columbia River for every year that the WCS was used to retain water. Vertical lines indicate the period of time within each water year (Oct. 1 - Sept. 20) that is considered the late season draw down period. Summary tables to the right of each graph indicate that length of time, the overall net difference (in feet) between gauges, and the average difference in water level over this period of time. 


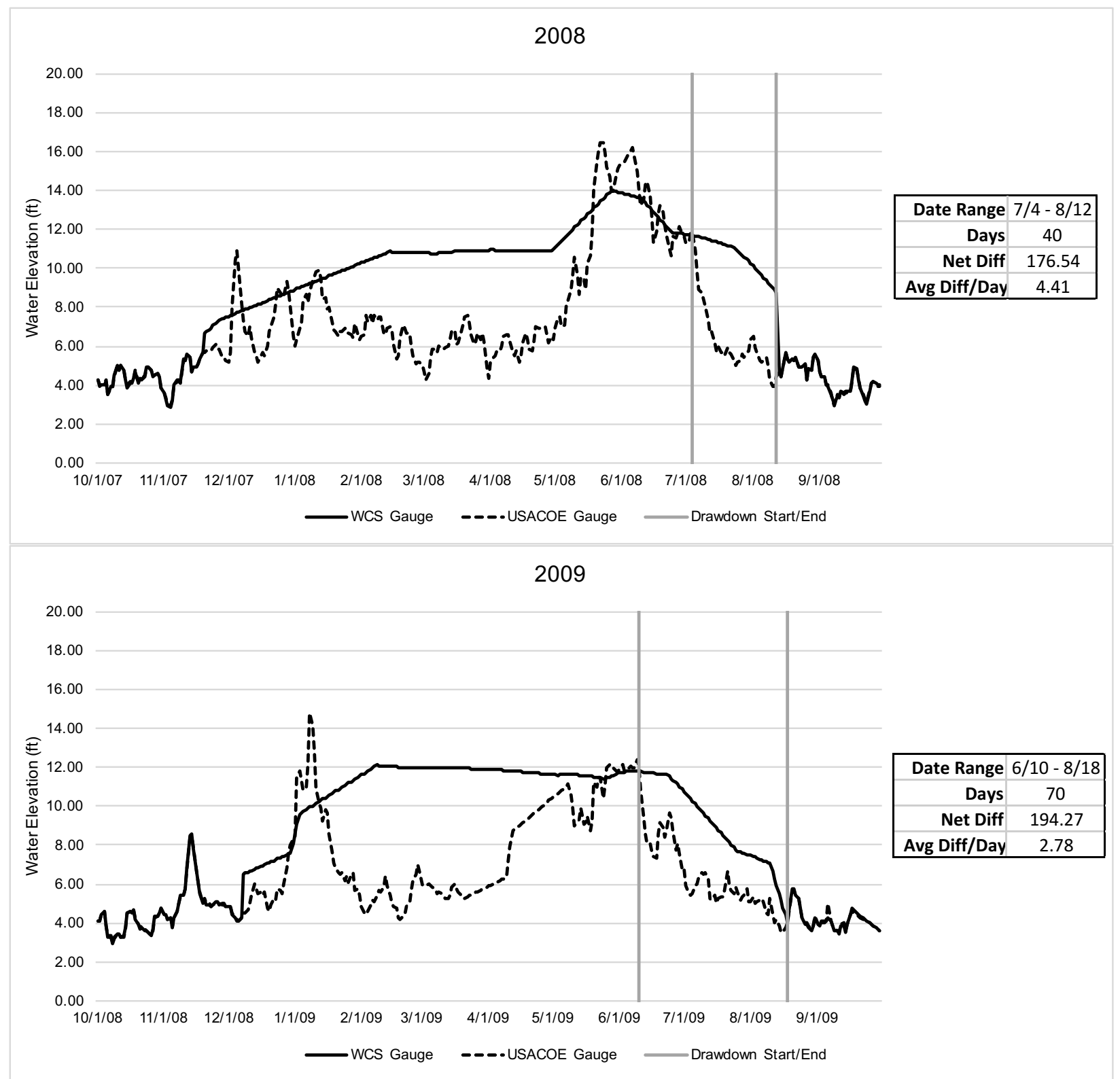

Figure B-2 continued: Changes to Annual WCS Late Season Drawdown.

Differences between the water control structure (WCS) gauge and the USACOE gauge located on the Columbia River for every year that the WCS was used to retain water. Vertical lines indicate the period of time within each water year (Oct. 1 - Sept. 20) that is considered the late season draw down period. Summary tables to the right of each graph indicate that length of time, the overall net difference (in feet) between gauges, and the average difference in water level over this period of time. 


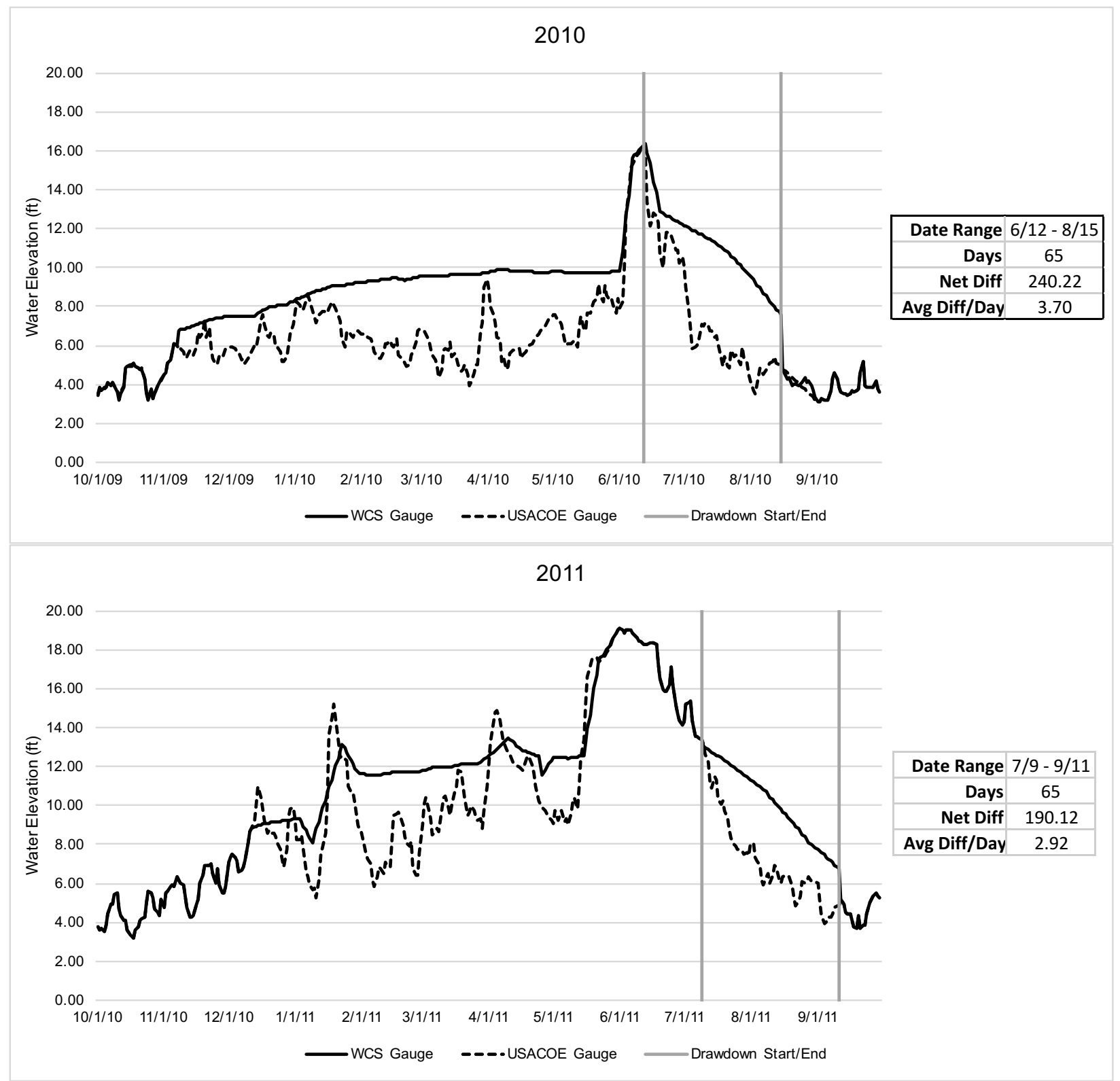

Figure B-2 continued: Changes to Annual WCS Late Season Drawdown.

Differences between the water control structure (WCS) gauge and the USACOE gauge located on the Columbia River for every year that the WCS was used to retain water. Vertical lines indicate the period of time within each water year (Oct. 1 - Sept. 20) that is considered the late season draw down period. Summary tables to the right of each graph indicate that length of time, the overall net difference (in feet) between gauges, and the average difference in water level over this period of time. 


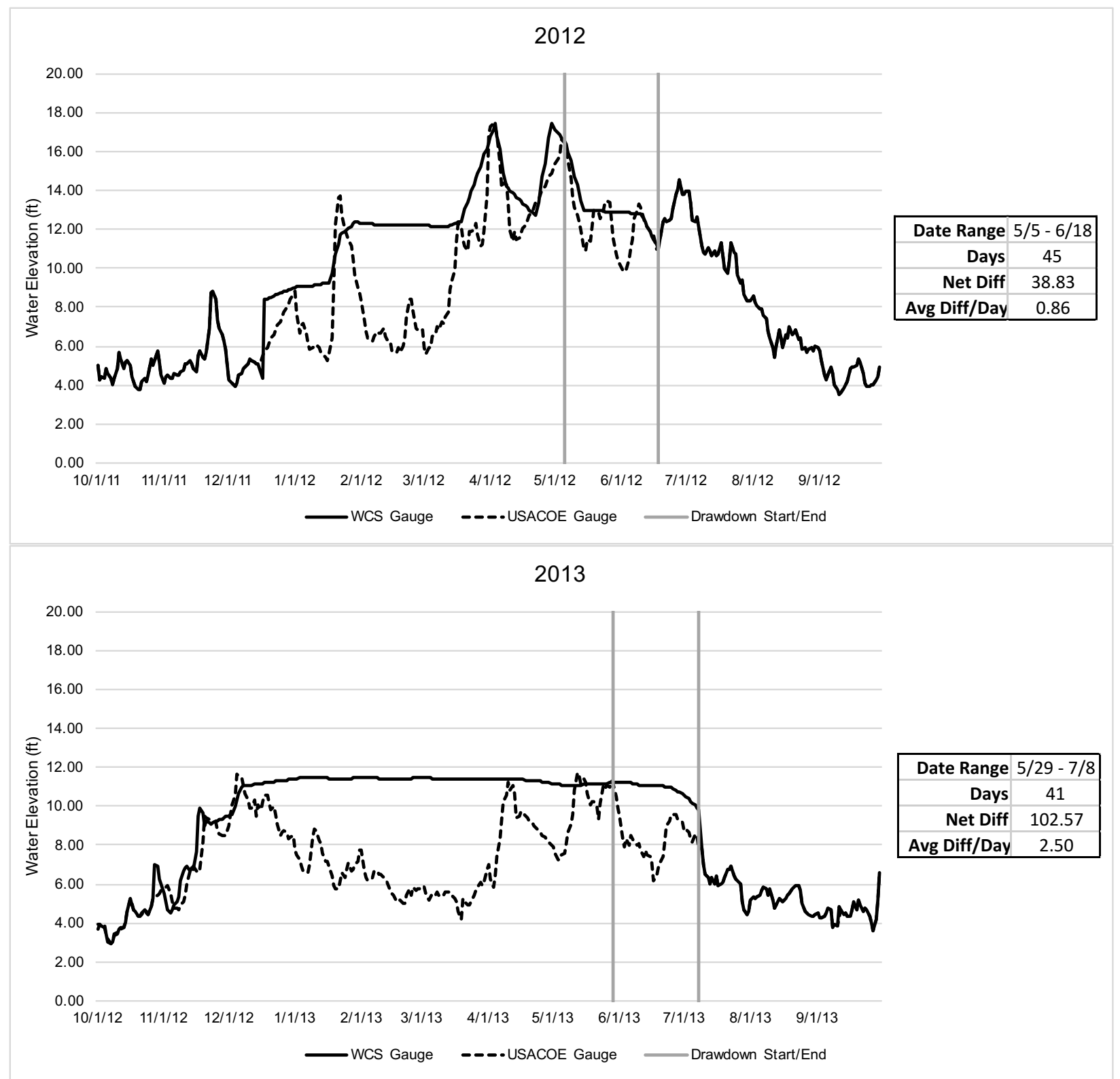

Figure B-2 continued: Changes to Annual WCS Late Season Drawdown.

Differences between the water control structure (WCS) gauge and the USACOE gauge located on the Columbia River for every year that the WCS was used to retain water. Vertical lines indicate the period of time within each water year (Oct. 1 - Sept. 20) that is considered the late season draw down period. Summary tables to the right of each graph indicate that length of time, the overall net difference (in feet) between gauges, and the average difference in water level over this period of time. 


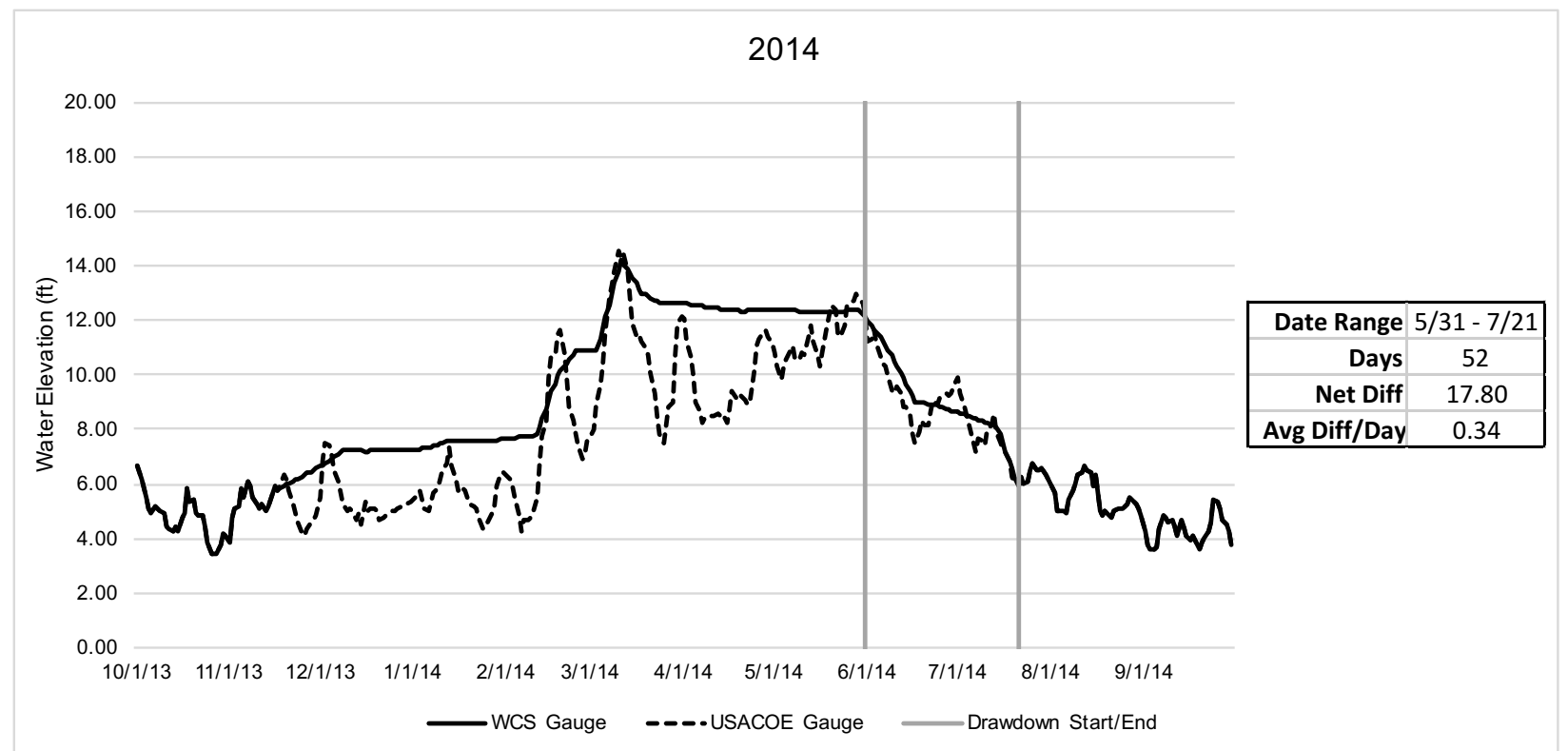

Figure B-2 continued: Changes to Annual WCS Late Season Drawdown.

Differences between the water control structure (WCS) gauge and the USACOE gauge located on the Columbia River for every year that the WCS was used to retain water. Vertical lines indicate the period of time within each water year (Oct. 1 - Sept. 20) that is considered the late season draw down period. Summary tables to the right of each graph indicate that length of time, the overall net difference (in feet) between gauges, and the average difference in water level over this period of time.

Table B-1: WCS Late Season Draw Down Period Wate Retention.

The amount of water retained within Smith and Bybee (SBW) during the drawdown period when the water control structure (WCS) would be slowly opened to flow from the Columbia River. Date Range represented the starting and ending dates of the draw down period. Days is the total number of days this process took. Net Difference and Average Difference/Day are the difference between the water elevation recorded within SBW by the WCS gauge and the water elevation found within the Columbia River mainstem (the amount of water retained within SBW).

\begin{tabular}{|c|c|c|c|c|}
\hline $\begin{array}{c}\text { Water } \\
\text { Year }\end{array}$ & Date Range & Days & $\begin{array}{c}\text { Net } \\
\text { Difference } \\
\text { (ft) }\end{array}$ & $\begin{array}{c}\text { Average } \\
\text { Difference/Day } \\
\text { (ft) }\end{array}$ \\
\hline 2004 & $6 / 2-7 / 27$ & 56 & 148.10 & 2.64 \\
\hline 2005 & $5 / 24-8 / 5$ & 74 & 164.98 & 2.23 \\
\hline 2006 & $6 / 17-8 / 30$ & 75 & 281.86 & 3.76 \\
\hline 2007 & $5 / 15-8 / 16$ & 94 & 303.58 & 3.23 \\
\hline 2008 & $7 / 4-8 / 12$ & 40 & 176.54 & 4.41 \\
\hline 2009 & $6 / 10-8 / 18$ & 70 & 194.27 & 2.78 \\
\hline 2010 & $6 / 12-8 / 15$ & 65 & 240.22 & 3.70 \\
\hline 2011 & $7 / 9-9 / 11$ & 65 & 190.12 & 2.92 \\
\hline 2012 & $5 / 5-6 / 18$ & 45 & 38.83 & 0.86 \\
\hline 2013 & $5 / 29-7 / 8$ & 41 & 102.57 & 2.50 \\
\hline 2014 & $5 / 31-7 / 21$ & 52 & 17.80 & 0.34 \\
\hline
\end{tabular}


Table B-2: Maximum Inundation and Dates of Occurrence Maximum inundation (ft) of water in Smith and Bybee Wetlands (SBW) and the corresponding dates in which maximum inundation occurred. Values were calculated for the annual maximum inundation and the maximum inundation reached during two month periods that are reflective of early growing seasons for multiple common species in SBW.

\begin{tabular}{|c|c|c|c|c|c|c|c|c|c|c|}
\hline & \multicolumn{10}{|c|}{$\begin{array}{l}\text { Annual and Early Growing Season Maximum Inundation (ft) } \\
\text { and Date of Occurance for All Years }\end{array}$} \\
\hline & $\begin{array}{l}\text { All } \\
\text { Year } \\
\text { Max } \\
\text { (ft) }\end{array}$ & $\begin{array}{l}\text { All Year } \\
\text { Date }\end{array}$ & $\begin{array}{l}\text { Mar - } \\
\text { Apr } \\
\text { Max } \\
\text { (ft) }\end{array}$ & $\begin{array}{l}\text { Mar - Apr } \\
\text { Date }\end{array}$ & $\begin{array}{c}\text { April - } \\
\text { May } \\
\text { Max } \\
\text { (ft) }\end{array}$ & $\begin{array}{c}\text { April - } \\
\text { May Date }\end{array}$ & \begin{tabular}{|l} 
May - \\
June \\
Max \\
(ft)
\end{tabular} & $\begin{array}{c}\text { May - } \\
\text { June Date }\end{array}$ & $\begin{array}{c}\text { June - } \\
\text { July } \\
\text { Max } \\
\text { (ft) }\end{array}$ & $\begin{array}{c}\text { June - July } \\
\text { Date }\end{array}$ \\
\hline 2003 & 10.78 & $\begin{array}{l}2 / 4 / 03- \\
2 / 5 / 03\end{array}$ & 8.96 & $4 / 25 / 03$ & 10.08 & $5 / 31 / 03$ & 10.44 & $6 / 3 / 03$ & 10.44 & $6 / 3 / 03$ \\
\hline 2004 & 10.97 & $3 / 2 / 04$ & 10.97 & $3 / 2 / 04$ & 10.88 & $4 / 1 / 04$ & 10.63 & $5 / 1 / 04$ & 10.36 & $6 / 1 / 04$ \\
\hline 2005 & 10.52 & $5 / 23 / 05$ & 8.86 & $4 / 25 / 05$ & 10.52 & $5 / 23 / 05$ & 10.52 & $5 / 23 / 05$ & 10.16 & $6 / 1 / 05$ \\
\hline 2006 & 16.55 & $1 / 13 / 06$ & 13.21 & $\begin{array}{l}4 / 29 / 06- \\
4 / 30 / 06\end{array}$ & 13.39 & $5 / 31 / 06$ & 13.40 & $6 / 2 / 06$ & 13.40 & $6 / 2 / 06$ \\
\hline 2007 & 12.04 & $\begin{array}{l}3 / 3 / 07- \\
3 / 13 / 07\end{array}$ & 12.04 & $\begin{array}{l}3 / 3 / 07- \\
3 / 13 / 07\end{array}$ & 11.98 & $\begin{array}{l}4 / 8 / 07- \\
4 / 10 / 07\end{array}$ & 11.85 & $5 / 1 / 07$ & 11.39 & $6 / 1 / 07$ \\
\hline 2008 & 13.98 & $5 / 27 / 08$ & 10.99 & $4 / 30 / 08$ & 13.98 & $5 / 27 / 08$ & 13.98 & $5 / 27 / 08$ & 13.84 & $6 / 1 / 08$ \\
\hline 2009 & 12.10 & $2 / 8 / 09$ & 12.00 & $3 / 2 / 09$ & 11.89 & 4/1/09 & 11.82 & $6 / 7 / 09$ & 11.82 & $6 / 7 / 09$ \\
\hline 2010 & 16.40 & $6 / 13 / 10$ & 9.88 & $\begin{array}{l}4 / 5 / 10- \\
4 / 6 / 10\end{array}$ & 9.88 & $\begin{array}{l}4 / 5 / 10- \\
4 / 6 / 10\end{array}$ & 16.40 & $6 / 13 / 10$ & 16.40 & $6 / 13 / 10$ \\
\hline 2011 & 19.06 & $6 / 1 / 11$ & 13.48 & $4 / 10 / 11$ & 18.98 & $5 / 31 / 11$ & 19.06 & $6 / 1 / 11$ & 19.06 & $6 / 1 / 11$ \\
\hline 2012 & 17.40 & $\begin{array}{l}4 / 3 / 12 \& \\
4 / 29 / 12\end{array}$ & 17.40 & $\begin{array}{l}4 / 3 / 12 \& \\
4 / 29 / 12\end{array}$ & 17.40 & $\begin{array}{l}4 / 3 / 12 \& \\
4 / 29 / 12\end{array}$ & 17.11 & $5 / 1 / 12$ & 13.60 & $7 / 2 / 12$ \\
\hline 2013 & 11.50 & $1 / 7 / 13$ & 11.44 & $\begin{array}{l}3 / 1 / 13- \\
3 / 5 / 13 \\
\end{array}$ & 11.40 & $4 / 8 / 13$ & 11.26 & $6 / 3 / 13$ & 11.26 & $6 / 3 / 13$ \\
\hline 2014 & 14.20 & $3 / 11 / 14$ & 14.20 & $3 / 11 / 14$ & 12.62 & $4 / 1 / 14$ & 12.40 & $\begin{array}{c}5 / 1 / 14- \\
5 / 2 / 14 \& \\
5 / 29 / 14\end{array}$ & 11.98 & $6 / 1 / 14$ \\
\hline 2015 & 12.38 & $2 / 11 / 15$ & 8.52 & $\begin{array}{l}3 / 23 / 15- \\
3 / 24 / 15\end{array}$ & 8.29 & $4 / 6 / 15$ & 7.44 & $5 / 19 / 15$ & 7.33 & $6 / 2 / 15$ \\
\hline 2016 & 13.31 & $12 / 10 / 15$ & 12.04 & $4 / 25 / 16$ & 12.04 & $4 / 25 / 16$ & 10.11 & $5 / 10 / 16$ & 8.60 & $6 / 7 / 16$ \\
\hline
\end{tabular}




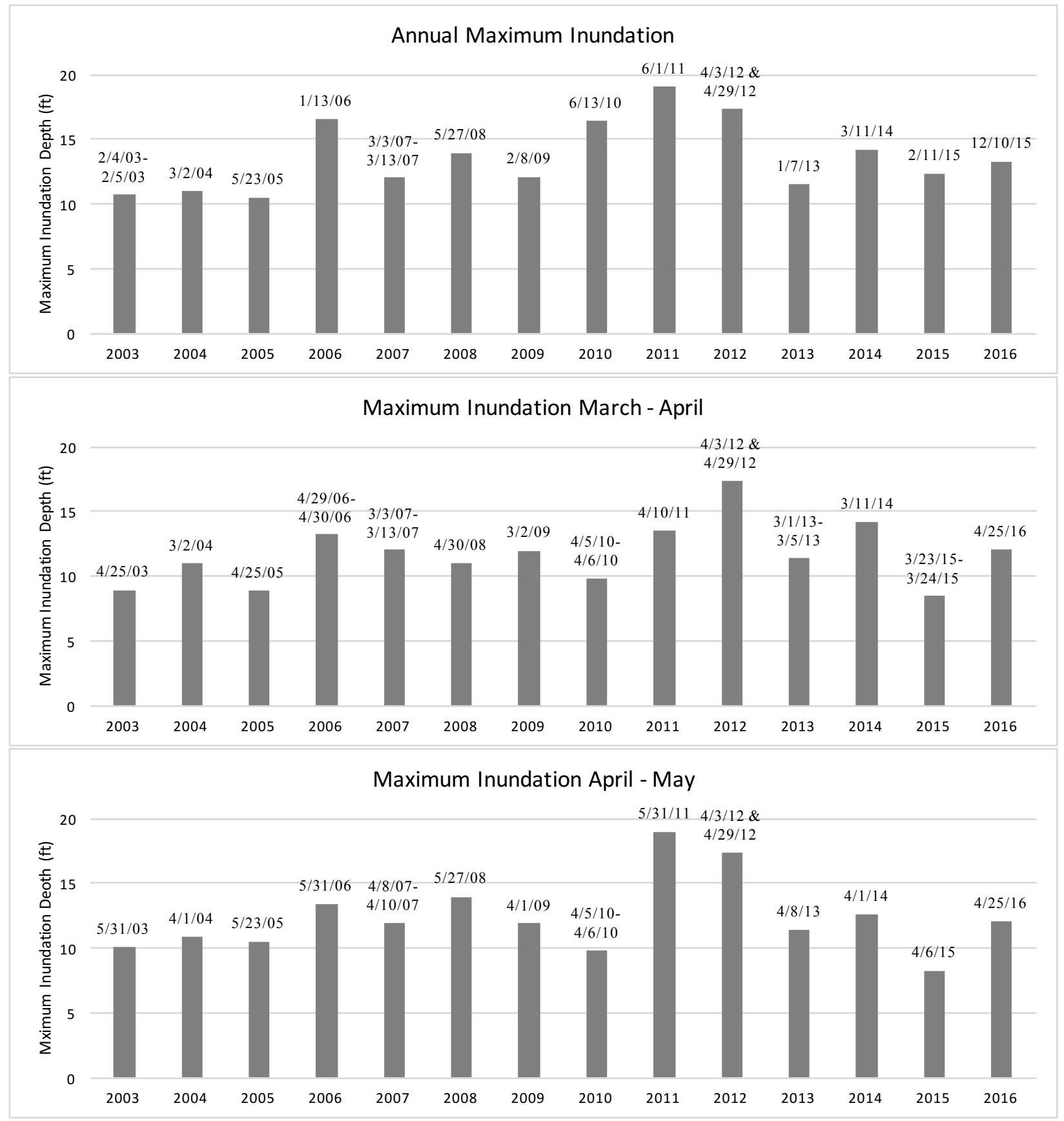

Figure B-3: Maximum Inundation for All Years Maximum Inundation (ft) of water experienced in Smith and Bybee Wetlands (SBW) for every year since the installation of the water control structure. Graphs indicate the annual maximum inundation and maximum inundation reached during two month periods that are reflective of early growing seasons for multiple common species in SBW. Labels above each bar indicate the date or dates ranges that maximum inundation occurred. 


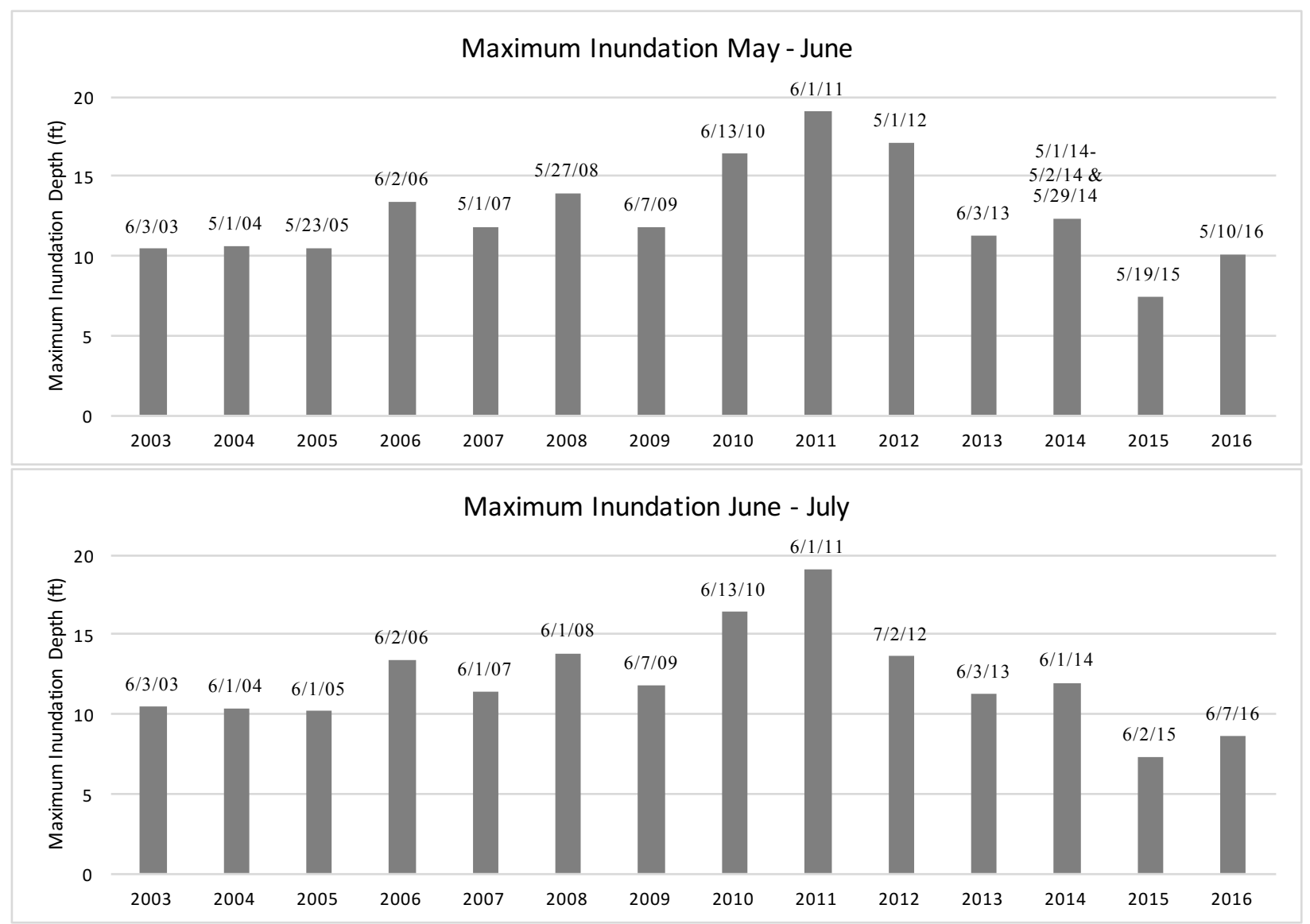

Figure B-3 continued: Maximum Inundation for All Years

Maximum Inundation ( $\mathrm{ft}$ ) of water experienced in Smith and Bybee Wetlands (SBW) for every year since the installation of the water control structure. Graphs indicate the annual maximum inundation and maximum inundation reached during two month periods that are reflective of early growing seasons for multiple common species in SBW. Labels above each bar indicate the date or dates ranges that maximum inundation occurred. 


\section{Appendix C: Community Composition 2003-2016}

Table C-1: Species Present in 2003 and 2016

All species that were surveyed in 2003 and 2016. The table includes all monitoring years that they were present, and each species' growth period, wetland indicator status, and native status.

\begin{tabular}{|c|c|c|c|c|c|c|c|c|c|c|}
\hline \multirow{2}{*}{ Species } & \multirow{2}{*}{ Wetland Status } & \multirow{2}{*}{ Growth Period } & \multirow{2}{*}{ Native Status } & \multicolumn{6}{|c|}{ Species Presence } & \multirow{2}{*}{$\begin{array}{c}\text { Number of } \\
\text { Years }\end{array}$} \\
\hline & & & & 2003 & 2004 & 2008 & 2009 & 2015 & 2016 & \\
\hline Bidens cernua & Obligate & Annual & Native & $\mathrm{x}$ & $x$ & $\mathrm{x}$ & $x$ & $x$ & $\mathrm{x}$ & 6 \\
\hline Eleocharis ovata & Obligate & Annual & Native & $\mathrm{x}$ & $\mathrm{X}$ & $\mathrm{X}$ & $\mathrm{X}$ & $\mathrm{X}$ & $\mathrm{X}$ & 6 \\
\hline Rorippa curvisiliqua & Obligate & Annual & Native & $\mathrm{X}$ & $\mathrm{X}$ & $\mathrm{X}$ & $\mathrm{x}$ & $\mathrm{X}$ & $\mathrm{X}$ & 6 \\
\hline Eleocharis palustris & Obligate & Perennial & Native & $\mathrm{X}$ & $\mathrm{x}$ & $\mathrm{x}$ & $\mathrm{x}$ & $\mathrm{X}$ & $\mathrm{X}$ & 6 \\
\hline Leersia oryzoides & Obligate & Perennial & Native & $\mathrm{X}$ & $\mathrm{X}$ & & & $\mathrm{X}$ & $\mathrm{X}$ & 4 \\
\hline Ludwigia palustris & Obligate & Perennial & Native & $\mathrm{x}$ & $\mathrm{x}$ & $\mathrm{x}$ & $\mathrm{X}$ & $\mathrm{x}$ & $\mathrm{x}$ & 6 \\
\hline Lythrum salicaria & Obligate & Perennial & Non-native & $\mathrm{x}$ & $\mathrm{x}$ & $\mathrm{x}$ & $\mathrm{x}$ & $\mathrm{x}$ & $\mathrm{X}$ & 6 \\
\hline Myriophyllum aquaticum & Obligate & Perennial & Non-native & $\mathrm{x}$ & $\mathrm{x}$ & $\mathrm{x}$ & $\mathrm{x}$ & & $\mathrm{x}$ & 5 \\
\hline Persicari amphibia & Obligate & Perennial & Native & $\mathrm{X}$ & $\mathrm{x}$ & $\mathrm{x}$ & $\mathrm{x}$ & $\mathrm{X}$ & $\mathrm{x}$ & 6 \\
\hline Schoenoplectus tabernaemontani & Obligate & Perennial & Native & $\mathrm{X}$ & $\mathrm{X}$ & & & $\mathrm{X}$ & $\mathrm{x}$ & 4 \\
\hline Gnaphalium palustre & Facultative (wet) & Annual & Native & $\mathrm{X}$ & $\mathrm{X}$ & & & $\mathrm{X}$ & $\mathrm{X}$ & 4 \\
\hline Epilobium ciliatum & Facultative (wet) & Perennial & Native & $\mathrm{X}$ & $\mathrm{X}$ & $\mathrm{X}$ & $\mathrm{X}$ & $\mathrm{X}$ & $\mathrm{x}$ & 6 \\
\hline Fraxinus latifolia & Facultative (wet) & Perennial & Native & $\mathrm{X}$ & $\mathrm{x}$ & $\mathrm{x}$ & $\mathrm{x}$ & $\mathrm{X}$ & $\mathrm{X}$ & 6 \\
\hline Lysimachia nummularia & Facultative (wet) & Perennial & Non-native & $\mathrm{X}$ & $\mathrm{x}$ & $\mathrm{x}$ & $\mathrm{x}$ & $\mathrm{X}$ & $\mathrm{X}$ & 6 \\
\hline Philaris arundinacea & Facultative (wet) & Perennial & Non-native & $\mathrm{X}$ & $\mathrm{X}$ & $\mathrm{X}$ & $\mathrm{x}$ & $\mathrm{X}$ & $\mathrm{X}$ & 6 \\
\hline Salix lucidia lasiandra & Facultative (wet) & Perennial & Native & $\mathrm{X}$ & $\mathrm{x}$ & $\mathrm{X}$ & $\mathrm{x}$ & $\mathrm{x}$ & $\mathrm{X}$ & 6 \\
\hline Cirsium arvense & Facultative & Perennial & Non-native & $\mathrm{x}$ & $\mathrm{x}$ & $\mathrm{x}$ & $\mathrm{X}$ & & $\mathrm{X}$ & 5 \\
\hline Rubus armeniacus & Facultative & Perennial & Non-native & $\mathrm{x}$ & $\mathrm{x}$ & $\mathrm{X}$ & $x$ & & $\mathrm{x}$ & 5 \\
\hline Cirsium vulgare & Facultative (up) & Biennial & Non-native & $\mathrm{x}$ & $\mathrm{x}$ & & & & $\mathrm{x}$ & 3 \\
\hline \multirow[t]{5}{*}{ Rubus ursinus } & Facultative (up) & Perennial & Native & $\mathrm{x}$ & $\mathrm{X}$ & $\mathrm{X}$ & $\mathrm{x}$ & $\mathrm{x}$ & $x$ & 6 \\
\hline & \multicolumn{9}{|c|}{ Totals } & \\
\hline & Obligate - 10 & Annual - 4 & Native - 13 & & & & & & & \\
\hline & Facultative - 10 & Perennial - 15 & Non-native - 7 & 20 & 20 & 16 & 16 & 16 & 20 & \\
\hline & Unknown- 0 & Biennial - 1 & Unknown - 0 & & & & & & & \\
\hline
\end{tabular}


Table C-2: Species Present in 2003 and Not Present in 2016

All species that were surveyed in 2003 that were no longer present in 2016. The table includes all monitoring years that they were present, and each species' growth period, wetland indicator status, and native status.

\begin{tabular}{|c|c|c|c|c|c|c|c|c|c|c|}
\hline \multirow{2}{*}{ Species } & \multirow{2}{*}{ Wetland Status } & \multirow{2}{*}{ Growth Period } & \multirow{2}{*}{ Native Status } & \multicolumn{6}{|c|}{ Species Presence } & \multirow{2}{*}{$\begin{array}{c}\text { Number of } \\
\text { Years Presen }\end{array}$} \\
\hline & & & & 2003 & 2004 & 2008 & 2009 & 2015 & 2016 & \\
\hline Azolla mexicana & Obligate & Annual & Native & $\mathrm{X}$ & & $\mathrm{X}$ & & & & 2 \\
\hline Myosotis laxa & Obligate & Annual & Native & $\mathrm{X}$ & $\mathrm{X}$ & & & & & 2 \\
\hline Ranunculus sceleratus & Obligate & Annual & Native & $x$ & $x$ & & & & & 2 \\
\hline Lemna minor & Obligate & Perennial & Native & $\mathrm{x}$ & & $x$ & $\mathrm{X}$ & & & 3 \\
\hline Typha latifolia & Obligate & Perennial & Native & $\mathrm{x}$ & $\mathrm{x}$ & & & & & 2 \\
\hline Veronica americana & Obligate & Perennial & Native & $\mathrm{x}$ & $\mathrm{x}$ & & & & & 2 \\
\hline Cyperus strigosus & Facultative (wet) & Perennial & Native & $x$ & $\mathrm{X}$ & $\mathrm{X}$ & $\mathrm{X}$ & & & 4 \\
\hline Deschampsia cespitosa & Facultative (wet) & Perennial & Native & $x$ & $\mathrm{X}$ & & & & & 2 \\
\hline Juncus effusus & Facultative (wet) & Perennial & Non-native & $x$ & $x$ & & & $\mathrm{X}$ & & 3 \\
\hline Mentha arvensis & Facultative (wet) & Perennial & Non-native & $x$ & $x$ & & & & & 2 \\
\hline Salix sessifolia & Facultative (wet) & Perennial & Native & $x$ & $x$ & $\mathrm{X}$ & $\mathrm{X}$ & & & 4 \\
\hline Gnaphalium uliginosum & Facultative & Annual & Non-native & $x$ & $\mathrm{X}$ & & $X$ & & & 3 \\
\hline Dipsacus fullonum & Facultative & Biennial & Non-native & $x$ & & & & & & 1 \\
\hline Lotus corniculatus & Facultative & Perennial & Non-native & $x$ & $x$ & & & & & 2 \\
\hline Ribes lacustre & Facultative & Perennial & Native & $x$ & & & & & & 1 \\
\hline Solanum dulcamara & Facultative & Perennial & Non-native & $x$ & $\mathrm{x}$ & $\mathrm{x}$ & $\mathrm{x}$ & $x$ & & 5 \\
\hline Galium aparine & Facultative (up) & Annual & Native & $x$ & $\mathrm{X}$ & & & & & 2 \\
\hline Hypericum perforatum & Facultative (up) & Perennial & Non-native & $\mathrm{X}$ & & & & & & 1 \\
\hline Sambucus racemosa & Facultative (up) & Perennial & Native & $\mathrm{X}$ & $\mathrm{x}$ & & & & & 2 \\
\hline Taraxacum officinale & Facultative (up) & Perennial & Non-native & $\mathrm{x}$ & $\mathrm{x}$ & & & & & 2 \\
\hline Rumex maritimus & Unknown & Annual & Native & $X$ & $\mathrm{X}$ & $\mathrm{x}$ & $x$ & & & 4 \\
\hline Betula species & Unknown & Unknown & Non-native & $\mathrm{X}$ & & & & & & 1 \\
\hline Cardamine species & Unknown & Unknown & Unkown & $x$ & $x$ & & & & & 2 \\
\hline Carex species & Unknown & Unknown & Native & $X$ & $X$ & $\mathrm{X}$ & $X$ & & & 4 \\
\hline Fabacea species & Unknown & Unknown & Unkown & $x$ & & & & & & 1 \\
\hline Fanleaf & Unknown & Unknown & Unkown & $x$ & & & & & & 1 \\
\hline Holcus species & Unknown & Unknown & Non-native & $x$ & $x$ & & & & & 2 \\
\hline Juncus species & Unknown & Unknown & Unkown & $x$ & & & & & & 1 \\
\hline Salix species & Unknown & Unknown & Unkown & $\mathrm{X}$ & $\mathrm{X}$ & & & & & 2 \\
\hline \multirow[t]{6}{*}{ Veronica species } & Unknown & Unknown & Unkown & $X$ & $x$ & $X$ & $x$ & & & 4 \\
\hline & \multicolumn{9}{|c|}{ Totals } & \\
\hline & Obligate - 6 & Annual - 6 & Native - 14 & & & & & & & \\
\hline & Facultative - 14 & Perennial - 14 & Non-native - 10 & 30 & 21 & 8 & 8 & 2 & 0 & \\
\hline & Unknown- 10 & Biennial - 1 & Unknown - 6 & & & & & & & \\
\hline & & Unknown - 9 & & & & & & & & \\
\hline
\end{tabular}


Table C-3: Species Present in 2016 and Not Present in 2003

All species that were surveyed in 2016 that were not present in 2003. The table includes all monitoring years that they were present, and each species' growth period, wetland indicator status, and native status.

\begin{tabular}{|c|c|c|c|c|c|c|c|c|c|c|}
\hline \multirow{2}{*}{ Species } & \multirow{2}{*}{ Wetland Status } & \multirow{2}{*}{ Growth Period } & \multirow{2}{*}{ Native Status } & \multicolumn{6}{|c|}{ Species Presence } & \multirow{2}{*}{$\begin{array}{c}\text { Number of } \\
\text { Years }\end{array}$} \\
\hline & & & & 2003 & 2004 & 2008 & 2009 & 2015 & 2016 & \\
\hline Cyperus erythrorhizos & Obligate & Annual & Native & & & & & $\mathrm{X}$ & $\mathrm{X}$ & 2 \\
\hline Eragrostis hypnoides & Obligate & Annual & Native & & $X$ & $X$ & $X$ & $\mathrm{X}$ & $\mathrm{X}$ & 5 \\
\hline Alisma trivial & Obligate & Perennial & Native & & & & & $\mathrm{X}$ & $\mathrm{X}$ & 2 \\
\hline Alopecurus aequalis & Obligate & Perennial & Native & & & & & & $X$ & 1 \\
\hline Carex aperta & Obligate & Perennial & Native & & & $\mathrm{X}$ & $X$ & $X$ & $\mathrm{X}$ & 4 \\
\hline Ludwigia peploides ssp montevidensis & Obligate & Perennial & Non-native & & & & & $\mathrm{X}$ & $\mathrm{X}$ & 2 \\
\hline Mentha pulegium & Obligate & Perennial & Non-native & & & & & & $\mathrm{X}$ & 1 \\
\hline Ricciocarpus & Obligate & Unknown & Unkown & & & & & $\mathrm{X}$ & $\mathrm{X}$ & 2 \\
\hline Pseudognaphalium luteoalbum & Facultative (wet) & Annual & Non-native & & & & & & $\mathrm{X}$ & 1 \\
\hline Cornus sericea & Facultative (wet) & Perennial & Native & & $X$ & $\mathrm{X}$ & $\mathrm{X}$ & $\mathrm{X}$ & $\mathrm{X}$ & 5 \\
\hline Spirea douglasii & Facultative (wet) & Perennial & Native & & & $\mathrm{X}$ & $\mathrm{X}$ & & $\mathrm{X}$ & 3 \\
\hline Echinochloa crus galli & Facultative & Annual & Non-native & & & & & & $\mathrm{X}$ & 1 \\
\hline Panicum capillare & Facultative & Annual & Native & & & & & $\mathrm{X}$ & $\mathrm{X}$ & 2 \\
\hline Plantago Major & Facultative & Perennial & Non-native & & & & & & $\mathrm{X}$ & 1 \\
\hline Populus trichocarpa ssp balsamifera & Facultative & Perennial & Native & & & & & $\mathrm{X}$ & $\mathrm{X}$ & 2 \\
\hline Acer macrophyllum & Facultative (up) & Perennial & Native & & & & & $\mathrm{X}$ & $\mathrm{X}$ & 2 \\
\hline Sonchus arvensis & Facultative (up) & Perennial & Non-native & & & & & & $\mathrm{X}$ & 1 \\
\hline Solanum species & Facultative (up) & Unknown & Non-native & & $\mathrm{X}$ & $X$ & $\mathrm{X}$ & $\mathrm{X}$ & $\mathrm{X}$ & 5 \\
\hline Sonchus deraceus & Upland & Annual & Non-native & & & & & $X$ & $X$ & 2 \\
\hline Arctium minus & Upland & Biennial & Non-native & & & & & $X$ & $\mathrm{X}$ & 2 \\
\hline Poacea species & Unknown & Unknown & Unkown & & & & & $X$ & $X$ & 2 \\
\hline Rosa pisocarpa & Unknown & Perennial & Native & & & & & & $X$ & 1 \\
\hline \multirow[t]{6}{*}{ Salix fluviatilis } & Unknown & Perennial & Native & & & & & & $\mathrm{X}$ & 1 \\
\hline & \multicolumn{9}{|c|}{ Totals } & \\
\hline & Obligate - 6 & Annual - 6 & Native - 14 & & & & & & & \\
\hline & Facultative - 14 & Perennial - 13 & Non-native - 10 & 0 & 1 & 1 & 1 & 5 & 8 & \\
\hline & Unknown- 10 & Biennial - 1 & Unknown - 6 & & & & & & & \\
\hline & & Unknown - 3 & & & & & & & & \\
\hline
\end{tabular}

